Portland State University

PDXScholar

\title{
An historical consideration of F.C. Baur, his life, works, and theological thought, especially in regard to his church history and historical theology
}

Steven Norman Goetz

Portland State University

Follow this and additional works at: https://pdxscholar.library.pdx.edu/open_access_etds

Part of the History of Religion Commons, and the Religious Thought, Theology and Philosophy of Religion Commons

Let us know how access to this document benefits you.

\section{Recommended Citation}

Goetz, Steven Norman, "An historical consideration of F.C. Baur, his life, works, and theological thought, especially in regard to his church history and historical theology" (1979). Dissertations and Theses. Paper 2899.

https://doi.org/10.15760/etd.2895

This Thesis is brought to you for free and open access. It has been accepted for inclusion in Dissertations and Theses by an authorized administrator of PDXScholar. Please contact us if we can make this document more accessible: pdxscholar@pdx.edu. 
AN ABSTRACT OF THE THESIS OF Steven Norman Goetz for the Master of Arts in History presented July 27, 1979.

Title: An Historical Consideration of F. C. Baur; His Life, Works, and Theological Thought, Especially in Regard to His Church History and Historical Theology.

APPROVED BY MEMBERS OF THE COMMITTEE:

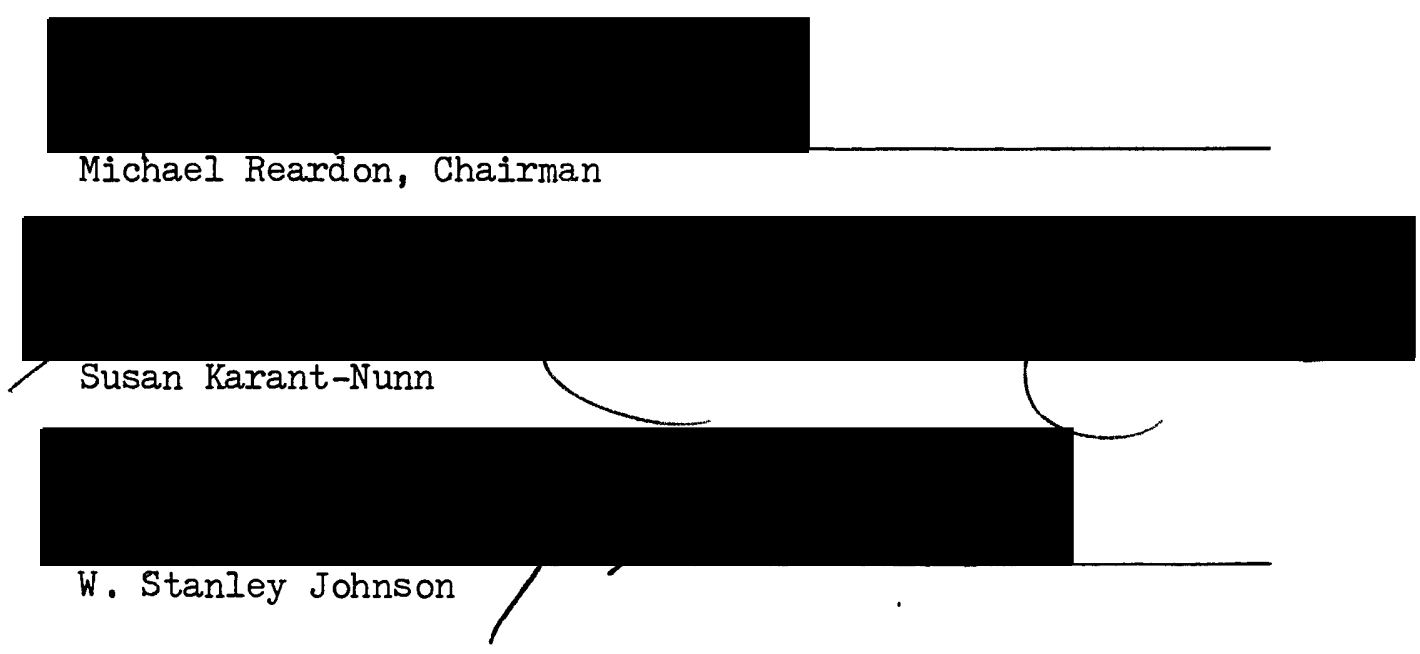

This thesis examines and evaluates F. C. Baur's philosophical and theological ideas as they relate to the writing of Church history and historical theology. The study is undertaken within the context of the problem of the relation between faith and history, which can be stated in more relewant categories for Church historiography as the problem of the relation between subject (faith) and object (history), and proposes that Baur's thought on this problem can be useful for the modern faith/ history debate, and especially for the consideration of writing Church history . 
The overall methodological approach of the study is historical, and begins (Chapter II) with a general description of the cultural environment in which Baur lived and worked. Here, four major cultural events are discussed which had an impact on his life, i. e. post-Kantian philosophy, with its rejection of the noumenal/phenomenal bifurcation of knowledge; the French Revolution; the Romantic Revolt; and, the early Historicist movement. Following this, in Chapter III, Baur's life, works, intellectual development, and theological thought are surveyed, in order to show how he fits into the cultural milieu of his day. It is discovered that he is essentially a romantic theologian, greatly influenced by Schelling, Schleiermacher, and Hegel, yet he does not quite fit the description of "romantic" due to his insistence on the objectivity, as well as the subjectivity, of reality. This is well illustrated, in Chapter IV by an analysis of his two works, The Epochs of Church Historiography, and Introduction to Lectures on the History of Christian Dogma, in which he asserts that both the objectivity (institutions and dogmas) and subjectivity (theological thought) of Christianity must be preserved in dialectical tension if the Church's true historical and ideal nature is to be understood.

In evaluation and conclusion (Chapter $V$ ), it is maintained that Baur's greatest legacy to theology is his firm insistence on both object and subject as factors in the historical development of Christianity, rather than on just one or the other. Within this balance, Baur points the way toward a view of Christianity which is neither overly-historical nor overly-theological, and calls for a Church historiography which incorporates them both. 
AN HISTORICAI CONSIDERATION OF F. C. BAUR: HIS LIFE, WORKS, AND THEOLOGICAL THOUGHT, ESPECIALLY IN REGARD TO HIS CHURCH HISTORY AND HISTORICAL THEOLOGY

by

STEVEN N, GOETZ

A thesis submitted in partial fulfillment of the requirements for the degree of

MASTER OF ARTS

in

HISTORY

Portland State University

1979 
TO THE OFFICE OF GRADUATE STUDIES AND RESEARCH:

The members of the Committee approve the thesis of

Steven Norman Goetz presented July 27, 1979.

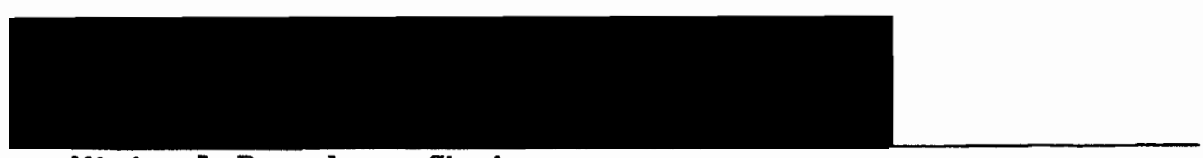

Michael Reardon, Chairman

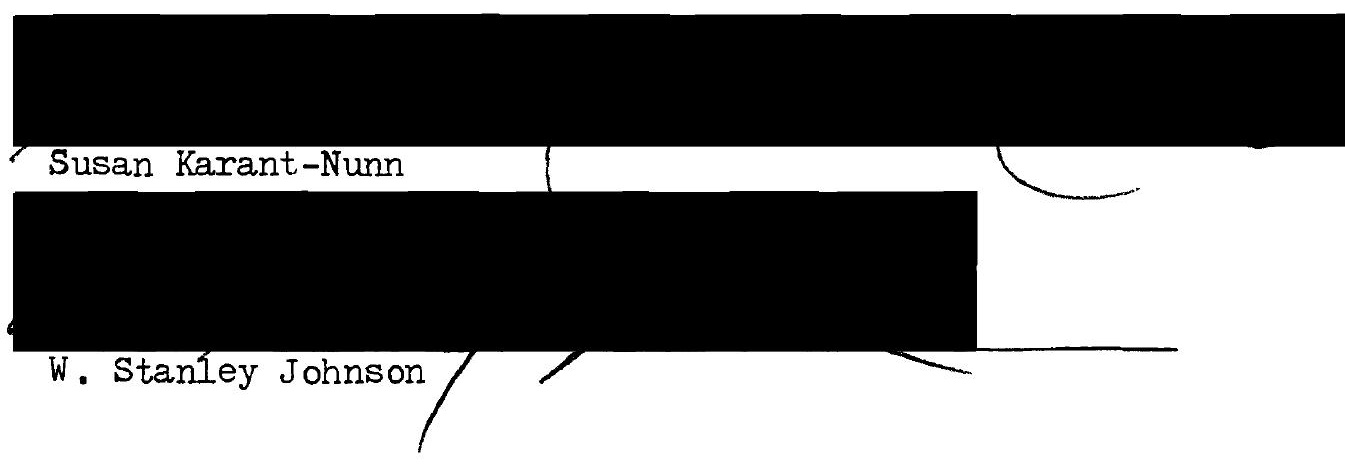

APPR OVED:

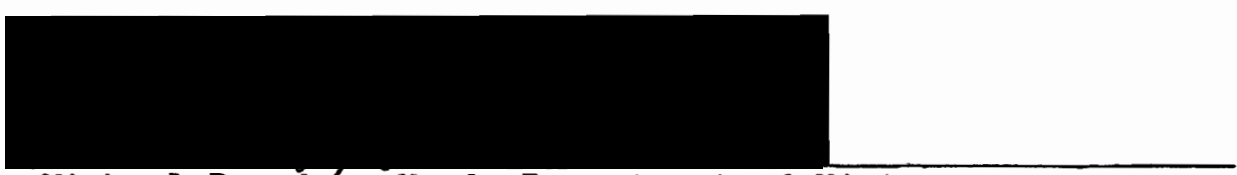

Michael Reardon, Head, Department of History

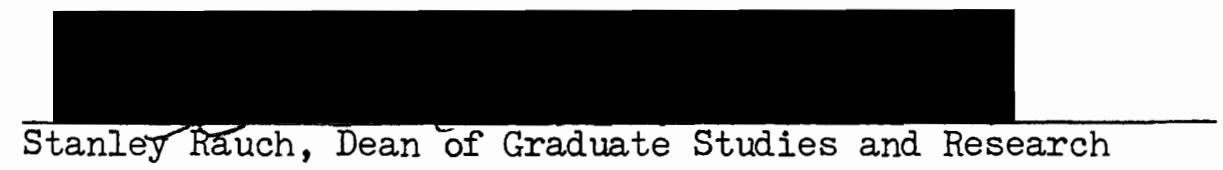


TABLE OF CONTENTS

CHAPTER

PAGE

I. INTRODUCTION . . . . . . . . . . . . . . 1

STATEMENT OF THE PROBLEM . . . . . . . . . . . 7

JUSTIFICATION OF THE PROBIEM . . . . . . . . . . 7

DELIMITATION . . . . . . . . . . . . . . 9

STATEMENT OF PROCEDURE . . . . . . . . . . . . 10

II. GERMANY AND THE ROOTS OF ROMANIICISM . . . . . . . . . . 12

THE INTELIECTUAL PREPARATION: FAITH

AND HISTORY . . . . . . . . . . . . . . . .

THE POLITICAL CATALYS'T: THE FRENCH

REVOLUTION . . . . . . . . . . . • . . . . •

THE CULTURAL RESPONSE: ROMANTICISM

AND HISTORICISM . . . . . . . . • • • . . • •

Romanticism . . . . . . . . . . . . 32

Historicism . . . . . . . . . . . . 42

SUMMARY .. . . . . . . . . . . . . . . . .

III. F. C. BAUR'S LIFE, WORKS, INTELIECTUAL DEVELOP-

MENT, AND THEOLOGICAL POSITION . . . . . . . . . . 50

$L I F E$. . . . . . . . . . . . . . . 50

WORKS .................... 59

INTELLECTUAL DEVELOPMENT . . . . . . . . . . 77

Schelling . . . . . . . . . . . . 81

Scheiermacher . . . . . . . . . 87

Hegel . . . . . . . . . . . . . 95

Baur's Christology ... . . . . . . . . 100 
IV. BAUR ON THE HISTORIOGRAPHY OF CHRISTIAN DOGMA AND THE CHURCH . . . . . . . . . . . 109

BAUR ON THE HISTORY OF DOGMA . . . . . . . . . . 111

BAUR ON THE WRITING OF CHURCH HISTORY . . . . . . 123

V. CONCLUSION AND EVALUATION . . . . . . . . . . 148 
CHAPTER I

\section{INTRODUCTION}

One of the most important and consuming questions of theological

investigation today is the problem of the relationship between faith and history. 1 The problem of faith and history can actually be considered as a particular theological form of a more general question

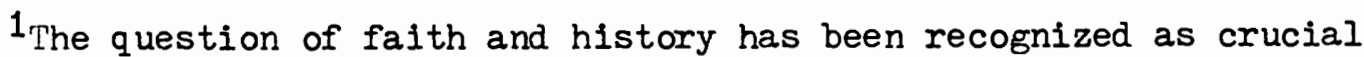
for Christian theology since at least the early nineteenth century, yet the problems associated with this question, particularly the problem of the development of Christian doctrine, have recently caused both CathoIic and Protestant theologians to consider the question more seriously. On the Catholic side, the second Vatican council has created a more tolerant attitude toward open speculation on sensitive theological issues, and has thus opened the way for consideration of the place of history for faith and the matter of doctrinal development. The ecumenical movement has also caused more concern over the question of faith and history because the division between Catholicism and Protestantism has been traced to a divergence over the question of doctrinal development. John Courtney Murray has written: "I consider that the parting of the ways between the two Christian communities (Roman Catholicism and Protestantism) takes place on the issue of development of doctrine" (quoted in Jaroslav Pelikan, Development of Christian Doctrine: Some Historical Prolegomena (New Haven and London: Yale University Press, 1969), p. 1.) If Murray is correct, then an adequate and acceptable solution to the problem of faith and history is vital to the life and success of the ecumenical movement.

On the Protestant side there is also a new and burgeoning interest in the question of faith and history. One example of this new interest is the so-called "New Quest for the historical Jesus" led by many of Rudolph Bultmann's former disciples such as Ernst Fuchs, Gerhard Ebling, Ernst Käsemann, and Gunther Bornkamm. This new quest is based on the dissatisfaction with dialectical theology's concept of history, and hopes to recover at least some element of historical value in the Iife of Jesus. Other examples are provided by Wolfhart Pannenberg's work Revelation as History, and the new interest in nineteenth century Iiberal theological thought focusing on such persons as F. C. Baur and Ernst Troeltsch (for Baur see especially Peter C. Hodgson, "The Rediscovery of Ferdinand Christian Baur. . . " Church History XXXIII: 2 (June, 1964), pp. 206-214; for Troeltsch see Ernst Troeltsch and the Future of Theology, ed. John P. Clayton, London: Cambridge University Press, 1976). 
concerning the relation between form and content in all reality which might be formulated historiographically as the relationship between ideas and history, or philosophically as the relationship between absolutes and particulars. The theological problem can be considered in various ways. For example, as applied to a believer's faith-response, the question of faith and history can be stated as: "To what extent is the truth and validity of the Christian faith dependent upon the occurrence of certain historical events?". In other words, is the truth of Christianity dependent upon the historical occurrence of such events as the birth, Iife, death and resurrection of Jesus as portrayed in the Gospels? Stated this way, the problem of faith and history is more a problem of theology. There is, however, another way of putting the question which makes it as much a question of historiography as of theology. From this perspective the question can be formulated: "To what extent, if any, does the absoluteness of Christianity reside in the historical structure and theological expressions of the Church?". In "other words, is it necessary that the phenomenal Church should embody absolutely, the ideality of Christianity for it to retain its dogmatic authority? It is with the latter formulation of the question of faith and history that this thesis is concerned, especially as it was addressed and answered by Ferdinand Christian Baur.

How the question of faith and history is answered in general will determine how the history of the Church and theology is written, for it is upon one's conception of the relationship between faith and history (between idea and history) that one's concept of the Church and its history is formulated. Those who separate faith and history will tend to separate Christianity (the ideal) from the Church (the historical) 
and consequently separate Church history from the history of theology. Those who identify faith and history as absolutely synonymous will be committed to one monolithic, absolute Church in history and will tend to see its dogmatical pronouncements as unqualifiedly single, unchanging and transhistorical. Both of these positions have difficulties.

In modern Protestant theology, the tendency has been to radically separate faith and history. This is most clearly seen in so-called Neo-Orthodox theology ep1tomized by German theologian Karl Barth who has insisted on a radical disjuncture between the faith-response of an. individual and the historical detalls of Jesus' life.2 With this separation accomplished, Barth, as a theologian, cared little for history; either New Testament history or Church history as a whole since it had so little to do with faith. He expressed his careless attitude toward history thus:

How frightfully indifferent I have become about the purely historical questions. Of course, that is nothing new for me. Already under the influence of Hermann, I always thought of historical criticism as merely a means of attaining freedom in relation to the tradition, not, however, as a constituting factor in a new Iiberal tradition. 3

Consequently, either Church history is considered as a completely theological discipline (i.e. a function of dogmatics) separate and distinct from the methodology of history, or it is considered as a completely historiographical discipline, separate and distinct from the methodology

2 For Barth's treatment of history in the theological task see his commentary The Epistle to the Romans, especially the discussion under Ch. iv. $17 \mathrm{~b}-25$ where he considers the value of history in relation to the Genesis account of Abraham.

3Quoted in Carl E. Braaten, History and Hermeneutics, Vol. II of New Directions in Theology Today (Philadelphia: The Westminster Press, 1964), p. 24. This statement not only indicates Barth's careless attitude toward history but also hints that he considers the historicalcritical method to be an essentially negative approach such as is exemplified in D. F. Strauss 'Leben Jesu. 
of history, or it is considered as a completely historiographical

discipline, separate and distinct from the methodology of theology.

Although there may be justification for both of these approaches to

Church history, according to Barth they must be carried on in total

isolation from one another. Thus, as Hodgson has pointed out,

Barth would remove Church history from the concept of history generally, and also, presumably, from the catagories of historical knowledge. In so far as the history of the Church can be regarded as an essentially theological discipline, it can be of interest and concern only to the theologian, not to the historian. There can be no critical, scientific, and at the same time theological historiography; critical historical science is not part of an authentically theological discipline. History can be rightly understood only from within the framework of dogmatics. 4

Barth is insistent about the separation of faith and history. In his history of nineteenth century theology, for example, he writes:

To describe and understand the history of Protestant theology from the time Schleiermacher onwards is a theological (italics) task. . . It is a conditio sine qua non of the success of our undertaking that it should be approached theologically, in accordance with its subject matter. 5

This method of approach to Church history is not an adequate one because it does not do justice to the historicity of the Church. In its zeal to understand the Church theologically or dogmatically, it fails to consider it historically. As F. C. Baur recognized in the nineteenth century and as other theologians are coming to realize today, Church history must involve both a theological and historical approach together if the Church is to be wholly understood. Jaroslav Pelikan,

${ }^{4}$ Peter C. Hodgson, The Formation of Historical Theology (New York: Harper and Row, Publishers, 1966), p. 270.

5 Karl Barth, Protestant Theology in the Nineteenth Century (Valley Forge: Judson Préss, 1973), p. 15. 
for example, has stated that the "investigation of the development of Christian doctrine in the history of theology is too important to be left to the theologians", 6 meaning that the history of theology is not to be monopolized any longer by theology alone. On the other hand, Pelikan recognizes the place of theology in the writing of Church history and states: "The history of the development of doctrine also deserves to be studied in its own right, without constantly being interpreted as an explicit function of the organizational, political and liturgical Iife of the Church."?

But if the writing of Church history suffers when the Church's abiding significance and its historical transitoriness are radically separated, the same is true when the historical Church is considered to be synonymous with Christianity itself. Under this concept of the Church, the historian must first demonstrate that something called the Church has always existed historically and that it has always remained unchanged. This concept of the Church was at the root of the Vincentian canon which identified Church dogma as that "quod ubique, quod semper, quod $a b$ ominibus creditum est." 8

In some ways, this dogmatic approach is founded upon a better model of the Church than the Neo-Orthodox approach, since it seems to consider both the theological and historical aspects of the Church. Yet this is only appearance. For when it absolutely identifies Christianity and the historical Church as synonymous, it is not able

6 Jaroslav Pelikan, Development of Christian Doctrine, p. 43. 7Ibid., p. 44.

8Jan Walgrave, Unfolding Revelation (Philadelphia: The Westminster Press, 1972), p. 87. 
in the final analysis to take the historicity of the Church seriously. Those who write Church history on the basis of the Vincentian canon are ultimately committed to present a Church which has not really changed at all, one which is not subject to the flux of history, and, thus, a Church which is transhistorical. In some cases, this method of Church history has led to some unfortunate results as, for example, is seen in treatments of the theology of the early Church fathers. Pelikan describes the method and its results thus:

Identifying those criteria of orthodoxy as' a summary of what, according to the Vincentian canon, must also have been in force during an earlier age, this method feels competent to adopt as fathers those who were the ancestors of orthodoxy and to condemn as heretics those who deviated from these later norms. Unfortunately, the ancestors of orthodoxy were in many instances also the thinkers who were found to have deviated from a later definition of orthodoxy. Thus an orthodoxy that, humanly speaking. could not have come into existence without them takes it upon itself to charge them with false doctrine.9

In sum, if the Neo-Orthodox solution, which either radically separates Church history and theology, or makes Church history a theological discipline, is inadequate to produce a wholistic treatment of the Church; and if, on the other hand, the dogmatic solution, based as it is on a conception of the Church that is essentially unhistorical, is also inadequate for the same purpose, then what is necessary is a method of Church history which takes into account both the Church's theological significance and its historicity, without over emphasizing either. This is perhaps the most important task in the field of Church history today, and, as Felikan has indicated, vital to the endeavor of producing a wholistic understanding of the Church. It is within the Christian Doctrine (Philadelphia: 'The Westminster Press, 1971), p. 21. 
context of the current need for a new theory of the relation between theology and Church history (i. e. between faith and history) that Ferdinand Christian Baur is introduced as the main subject of this theses.

\section{STATEMENT OF THE PROBLEM}

The purpose of this thesis is to critically and historically consider Ferdinand Christian Baur's life and works on Church history, and to attempt to interpret these in the historical context of his own time. The primary emphasis of this work is historical, although Baur's theological views will be alluded to and discussed as they relate to his significance for the historical development of theological thought. Stated more specifically, this thesis will attempt to interpret Baur in the setting of nineteenth century Germany, in the light of political, cultural, and intellectual movements. It will attempt to understand his views on the Church including not only his concept of its nature (i. e. theological nature) and positivity. (its historical nature), but also how he combines ideality and positivity in his treatment of Church history. Baur's views on the Church within the categories stated above, will also be considered for their abiding significance in the field of Church history but this is not included in the primary purpose of the paper.

\section{JUSTIFICATION OF THE PROBLEN}

'This study is undertaken in the belief that Baur cannot be fully understood only from a theological perspective, and therefore that a predominantly historical (but also theological) treatment is necessary 
for an adequate understanding of him. Baur has been thoroughly treated theologically in a number of works, both in English and German, 10 but relatively very little has been written on him which specifically seeks to understand him in the light of his historical surroundings. 11 In addition, Baur's work has not received much attention for its historiographic importance. 12

Beyond these reasons, a study of Baur such as this one, is important in considering the nature of Church history and the task of writing 1t. In fact, Baur is particularly important in this regard, for he was personally concerned with developing a method of Church history which would include and balance both the ideality and positivity of the Church. He is somewhat unique in his attempt at this, for as Hodgson has observed:

Baur is an essential link between Schleiermacher at one end of the nineteenth century and Ritschl and Harnack at the other; but his historical theology belongs neither to Schleiermacher on the one hand nor to the Protestant liberalism of which Ritschl was the father on the other. It represents a third, independent and autonomous theofogical position, yet one which links the other two together. 13

${ }^{10}$ Important here are, in English, Hodgson's book already cited and, in German, Wolfgang Geiger's Spekulation und Kritik: Die Geschichtstheologie Ferdinand Christian Baurs Munchen: Chr. Kaiser Verlag, 1964.

11 Apart from brief comments in encyclopedia essays and journal articles, I have discovered no such account of Baur's Iife, except Gustav Fraedrich's Ferdinand Christian Baur: Der Begrunder der Tubinger Schule als Theologie, Schriftsteller, und Charakter, which was published in 1909.

12 Most Iiturature discussing Baur as an historian is found in the form of journal articles in the German language. Refer to the bibliography for these references. Peter Hodgson has published an English translation of some of Baur's writings on Church history in Ferdinand Christian Baur on the Writing of Church History New York: Oxford University Press, 1968.

13peter C. Hodgson, The Formation of Historical Theology, pp. 277-78, in the footnotes. 
In distinction from those who preceded him (Schelling, Schleiermacher, and Hegel) Baur worked against the acosmic tendencies of Idealism which threatened to swallow up (aufheben) the particular aspects of history, specifically Church history, in general. In this regard he can be viewed as a champion of immanence for he strove to maintain a sense of historicity in the writing of Church history. On the other hand, in distinction from those who chronologically followed him (Ritschl, Harnack, and Troeltsch) he worked against the atheistic tendencies of extreme historicism which tended to reduce history, specifically Church history, to mere particulars. In this regard he can be viewed as the champion of transcendence, for he strove to maintain a sense of absoluteness in Church history. His methodology of Church history is the locus of his abiding importance and greatness which, according to Hodgson,

consists in his recognition of the radically historical quality of the Christian Church and Christian faith, and in his concommitant development of an historical method appropriate to a critical and theological study of the church and its founding events, a study which he understood to be an intrinsically proper and necessary theological discipline. 14

\section{DELIMITATION}

As indicated above, this paper is more concerned with an historical explication of F. C. Baur's life and work, specifically his works on Church history and the history of dogma, than it is in his theological ideas. Therefore, this study will primarily be limited to a consideration of his ideas on historiography as applied to Church history. The primary works for consideration will be Baur's The Epochs of Church

${ }^{14}$ Peter C. Hodgson, "Rediscovery of F. C. Baur. . .," p. 206. 
Historiography, and the Introduction to Lectures on the History of Christian Dogma. There is good reason to consider these works as the most important of Baur's life, because, coming at the end of his life, they represent his most independent works and are also reflective of his most mature development as a scholar.

\section{STATEMENT OF PROCEDURE}

This work will follow the inductive method in evaluating Baur's works and proceed in five separate chapters. Chapters one and two aim at describing the historical milieu in which Baur lived and worked. The introduction in chapter one attempts a formulation of the problem of faith and history in terms of the writing of Church history and discusses the relevance of F. C. Baur's thought to this contemporary methodological problem. Chapter two will consider nineteenth century Germany in general, in terms of philosophy, politics, and culture.

Chapters three and four are devoted to F. C. Baur himself. In chapter three, Baur's life and thought will be considered in historical context, specifically regarding his intellectual development and theological position. 15 Chapter four will be strictly devoted to Baur's

15 Here, the emphasis can only be on Baur's place in historical theology rather than his political opinions, since he rarely spoke out on political issues except when duty called for it, and then he demonstrated more concern for his theological work than political events. An example is a speech which he wrote and delivered on the occasion of the twenty-fifth year of the reign of King Wilhelm I of Wurttemberg. According to Hodgson, the speech "extolled the liberality and beneficence of the Wurttemberg regime, pointed to the growing sense of national (i.e. German) unity and identity, and then argued for the place of Hegelian speculation in scientific theology". (The Formation of Historical Theology, p. 18.) 
ideas on the writing of Church history and dogma, and will be essentially descriptive.

Chapter five will be both a critical evaluation of Baur's ideas on the writing of Church history, and a consideration of the significance of his ideas and work for the task of writing Church history today. 


\section{CHAPTER II}

\section{GERMANY AND THE ROO'S OF ROMANIICISM}

The nineteenth century was an extremely revolutionary time for all of Europe in general, but the Germanic countries especially, experienced cultural ferment and social displacement such as had not occurred there since the Reformation. Much of this displacement was born out of Germany's 1 own unique historical circumstances, yet, two areas of Germanic life, in particular, philosophy and politics, contributed to, and exemplify, the uncertainty of the age. Philosophy provided the internal impetus towards change; and politics, specifically the French Revolution, provided the external impetus. In philosophy, the idea that man, through his own reason, could perceive and have access to nature and history, was challenged and undermined by Immanuel Kant in his Critique of Pure Reason. This development effectively brought about a decline in the Enlightenment belief in the efficacy of human reason, and also paved the way for a split between faith and history, or, more specifically, between the material of Christianity (the historical facts), and the

It is with qualification that I speak here of Germany, for there was no "Germany" at this time at least as it existed later in the late nineteenth century. Still, there did exist some sense of unity among Prussians, Austrians and Rhinelanders in contrast to the French or the English. Crane Brinton writes of the Holy Roman Empire "As institution it was no doubt already dead, and certainly, in the opinion of literary men, buried. Yet it has some claim to be considered a real Germany, a Germany which provided even in the late eighteenth century some sort of focus for patriotic feelings." (A Decade of Revolution (New York: Harper and Brothers.Publishers, 1934), p. 73.) 
meaning of Christianity (its essential idea).

In the meantime, while this philosophical upheaval was going on in Germany, an event of earth-shaking consequences occurred outside of Germany which was ultimately to catapult it into the modern world politically, i.e. the French Revolution and the subsequent Napoleonic wars. Indeed, as Brinton remarks, the history of Germany as a modern nation truly begins with the Revolution. 2 These revolutionary events acted like a catalyst to activate cultural movements already present in Germanic society, which, when combined with the work of Kant, produced a new flowering and effulgence of culture.

The purpose of this chapter is to briefly sketch these two movements, i.e. the philosophical and political developments in Germany, in order to better understand the cultural environment which resulted from them. Having done this, the discussion will proceed to a consideration of two culture responses to these forces, Romanticism and Historicism. These two cultural phenomena are especially important to this discussion because they are not only paradigmatic examples of cultural developments in Germany during this time, but were also tremendously influential in F. C. Baur's intellectual development and scholarly writings. The examination of the philosophical preparation as seen in the problem of the relation between faith and history will be discussed first, followed by the political movements of the French Revolution and Napoleonic Wars.

2 As Brinton notes, "The Revolution was to destroy the Empire as an institution: The nineteenth century was to build up a German nation state on a pattern quite as modern as that of England and France." A Decade of Revolution, p. 73-74. 
THE INTELLECTUAL PREPARATION: FAITH AND HISTORY

In discussing the movements which led up to a bifurcation of faith and history, it is necessary to begin outside of Germany, with two English philosophers, John Locke (1632-1704) and David Hume (1711-1776). Locke was most concerned with the philosophical question of epistemology and outlined his views on this subject in An Essay Concerning Human Understanding. In this work, Locke showed himself to be a rationalist, fully committed to a belief in the efficacy of reason, maintaining that the subject (man) can know the world simply through his perception and reason. His emphasis on rational perception through the senses place him in the category of an empiricist philosopher. As a Christian, committed to reason, Locke had, naturally, to come to grips with the question of faith and reason and did so by making a distinction between truths, above, contrary, and according to reason. On the content of each of these categories, he wrote:

According to reason are such propositions whose truth we can discover by examining and tracing those ideas we have from sensation and reflection; and by natural deduction find to be true or probable. Above reason are such propositions whose truth or probability we cannot by reason derive from those principles. Contrary to reason are such propositions as are inconsistent with or irreconcilable to our clear and distinct ideas. Thus, the existence of one God is according to reason; the existence of more than one God, contraxy to reason; the resurrection of the dead, above reason. 3

His classification of "resurrection of the dead" as only above reason may seem surprising, coming from a rationalist, yet Locke had not developed the further implications of rationalism as did later Enlightenment philosophers. He did not polarize faith and reason, but rather,

3John Locke, An Essay Concerning Human Understanding Bk 4, Ch. 17, para. 24. 
considered them as functioning together. Still, in Locke's view, reason must take priority in the relationship of faith and reason for "he that believes without having any reason for believing, may be in love with his own fancies".4 Locke essentially reverses Anselm's fides quaerens intellectum to read intellectus quaerens fidem and this represents an important shift with far reaching implications. He left a place for faith, but it was a faith based upon data, which, even though provided by God, was to be recognized and understood by reason alone. This fact is clear by the way he distinguished faith and reason. He writes: Reason, therefore, here, as contradistinguished to faith, I take to be the discovery of the certainty or probability of such propositions or truths which the mind arrives at by deduction made from such ideas, which it has got by the use of its natural faculties; viz. by sensation or reflection. Faith, on the other side, is assent to any proposition, not thus made out by the deductions of reason, but upon the credit of the proposer, as coming from God, in some extra ordinary way of communication. This way of discovering truths to men we call revelation. 5

In the above quote, Locke provides a clue to his understanding of the relation of faith and reason. The miraculous accounts in the Bible are only "above reason" because of Locke's judgment that they are reliable historical documents (given by God) which attest to events as they actually occurred. In other words, the Gospel miracles are so well attested by such trustworthy persons that we can be confident of their occurrence. Locke stated this clearly in his A third Letter Concerning

\section{Toleration:}

For, when you tell us that "you are sure, I cannot say the Christian religion is still accompanied with miracles, as it was, at its first planting". I hope you do not mean that the

\footnotetext{
$4 \mathrm{~J}$ ohn Locke, An Essay.... Bk. 4, Ch. 17, para. 24.

5John Locke, An Essay.... Bk. 4, Ch. 18, para. 2.
} 
Gospel is not still accompanied with an undoubted testimony, that miracles were done, by the first publishers of it, which was as much of miracles as I suppose the greatest part of those had with whom the Christian religion prevailed, till it was "supported and encouraged as you tell us, by the laws of the Empire, which was not till the fourth century, had actually miracles done before them, to work upon them. And all those, who were not eye-witnesses of miracles, done in their presence, tis plain, had no other miracles than we have, that is upon report; and 'tis probable, not so many, nor so well attested, as we have. 6

In the above quote, Locke demonstrates implicitly his conviction that faith is based soundly upon historical occurrences which are indisputable. For him, Christianity is a given religion, but more than that, it is an historically given religion. That there is a metaphysical dualism operating in Locke's works, is clear. In his works, we are presented with a picture of the autonomous subject standing before objective reality and perceiving it directly. As the implications of rationalism were pressed farther by later philosophers (Hume, Berkley, Lessing) the problems of rationalism, (for example its subjectivity) became evident.

Here, the name of David Hume is important. Hume, like Locke, was a rationalist and empiricist who was himself much concerned with epistemology. He went beyond Locke, however, in his more consistent application of experience as a check on belief. What is contrary to experience? is thereby contrary to reason. On this basis, Hume rejects Locke's categories of phenomena above, according to, and contrary, to reason. A

6John Locke,"A Third Letter Concerning Toleration" in the Reasonableness of Christianity. ed. I. T. Ramsey (Stanford, Cal.: Stanford University Press, 1958), p. 91.

7 By experience, Hume doesn't mean only his own experience but rather human experience collectively as it is judged by reason. Ultimately, Hume's own judgments on what testimony is rationally acceptable and what is not, leads him to gross subjectivism and in this, although Hume wasn't particularly aware of it, he provides the greatest critique of his own system. 
revelation, according to him, which is based on miracles is incredible

and no amount of testimony can establish that the miraculous has occurred. In fact, any witness who testifies that the miraculous has happened is to be judged, ipso facto, as unreliable. Hume writes:

That no testimony is sufficient to establish a miracle, unless the testimony be of such a kind, that its falsehood would be more miraculous, than the fact, which it endeavours to establish; and even in that case there is a mutual destruction of arguments and the superior only gives us an assurance suitable to that degree of force, which remains, after deducing the inferior. When anyone tells me, that he saw a dead man restored to life, I immediately consider with myself, whether it be more probable, that this person should either decelve or be deceived, or that the fact, which he relates, should really have happened. I weigh the one miracle against the other; and according to the superiority, which I discover, I pronounce my decision, and always reject the greater. 8

Hume goes on to give reasons for his suspicion of accounts of the miraculous. In the first place, no account of miracle has ever been accompanied by the testimony of men, whose repute made it probable.9 Second, Hume himself had observed that human beings are susceptible to belief in the wonderful and miraculous because, "the passion of surprise and wonder, arising from miracles, being an agreeable emotion, gives a sensible tendency towards the belief of those events, from which it derived."10 Third, and finally, Hume argued that the accounts of the miraculous and wonderful come usually from the credulous and uncivilized nations. 11 On the basis of these observations, he rejects any notion of Christianity

8David Hume, An Enquiry Concerning Human Understanding (Chicago: The Open Court Publishing Co., 1927), p. 121.

9 David Hume, An Enquiry..., p. 122. 10David Hume, An Enquiry..., p. 122. 11David Hume, An Enquiry..., p. 125. 
as being a matter of established testimony. History is not an adequate foundation on which to place the truth of Christianity, since testimony, especially that testimony found in the Bible, is most fallible. Hume polarizes faith and reason, and consequently faith and history, in his consideration of the basis of Christianity. The subjectivity which was emerging in Locke is explicit in Hume when he distinguishes faith and reason in the context of discussing the basis for Christianity:

Our most holy religion is founded on faith, not on reason; and it is a sure method of exposing it to put it to such a trial as it is, by no means, fitted to endure. . .So that, upon the whole, we may conclude, that the Christian Religion not only was first attended with miracles, but even at this day cannot be believed by any reasonable person without one. Mere reason is insufficient to convince us of its veracity: And whoever is moved by faith to assent to it, is conscious of a continued miracle in his own person, which subverts all the principles of his understanding, and gives him a determination to believe what is most contrary to custom and experience. 12

Whereas for Locke, faith was based upon the reasonable acceptance of historic testimony, for Hume, no such acceptance was possible, at least where the testimony involved miracle. Faith, for him, was accepting something as true, which goes utterly contrary to reason, or, simply believing an assertion one knows (rationally) to be false. The move of rationalism towards subjectivity was facilitated by Hume because he tended to deny objectivity to history. The subject not only stands in judgment of objectivity, but also determines its bounds, and consequently, the subject is not open to reality at all, but rather, determines it for himself. Gotthold Iessing (1729-1781) dealt with the same problem of the relation between faith and history as Hume had, but found his own solution which was not as rigidly rational as Hume's. In fact, Lessing

12David Hume, An Enquiry..., p. 137-138. 
is somewhat of a progression beyond Hume in that he distinguishes and separates faith and history without pronouncing a negative judgment on either. This is the locus of his abiding significance, according to Allison, who claims that with Lessing "for the first time in the eighteenth century the question of the facticity of the Christian revelation was held to be irrelevant for the truth of the Christian religion."13 Lessing held that any written history, sacred or profane, could, at best provide only probability of the occurrence of events, and therefore, the truth of Christianity must not rest solely on historical grounds. Further, for him, any faith based upon the attestation of a historical document was more a faith in the credibility of the witness himself rather than a faith in what he proposed. Such a method of attestation had far-reaching consequences, according to Lessing. The miracles which were required to support Jesus' message in his own day, were themselves in need of more miracles to support them, as the message of their occurrence was proclaimed by his disciples later. Further, the miracles of the early Church were in need of further miracles to add credence to the accounts of the miraculous in the early church documents. This progression, Lessing termed the "proof of the proof". But, Lessing noted, this "proof of the proof" had lapsed in his own day, and consequently:

If then this proof of the proof has now entirely lapsed; if then all historical certainty is much too weak to replace this apparent proof of the proof which has lapsed: How is it to be expected of me that the same inconceivable truths which sixteen to eighteen hundred years ago people belleved on the strongest Inducement?14

13Henry E. Allison, Lessing and the Enlightenment (Ann Arbor, Mich.: The University of Chicago Press, 1966), p. 96.

14 Gotthold Lessing On The Proof of the Spirit And Of Yower trans. by Henry Chadwick (Stanford, Cal.: Stanford University Press, 1956), p. 53. 
Lessing's comments above indicate that his attack was not on the possibility of miracle nor the reliability of the historical accounts of them. Those things might have been an adequate foundation for Christian faith in another age, but they were no longer acceptable in his own. Regarding miracles, he wrote, "I deny that they can and should bind me in the least to a faith in the other teachings of Christ."15 Rather, the acceptance of Christian teachings, which in a more primitive time, had to be based on signs, could now be based strictly on rational reflection. Reason was now capable, being more highly developed, of understanding the great truths of Christianity apart from its historicity and therefore, for Lessing, the historical details were not as important as what they contained, i.e. the great moral truths of Christianity. Although there is a sense of objectivity, a sense of an abiding truth in Christianity, in Lessing's ideas, he is still fully within the rationalist position. The subject still determines the abiding truths of reality, he is still very much autonomous. But Lessing creates a gap between faith and history by his assertion that the historic testimony and its subject can be separated like idea and manifestation. Further, Lessing sees the historic manifestation as dispensable whereas the real important and essential truth remains. He carried out this distinction between faith and history because Hume had made Christianity suspect by his critique of the Biblical documents. In Iessing's work, the question of miracle and historicity was irrelevant to Christian truth because Christianity contained abiding and absolute truths discoverable by reason. But in doing this, he effectively polarized idea and manifestation and thus created a chasm between object and subject. Kant carried this further. 
Immanuel Kant (1724-1804) is best known for his work, the Critique of Pure Reason in which he demonstrated the limits of reason and postulated two aspects of reality: the noumenal and the phenomenal. Kant went on later to apply his ideas to Christianity in his Religion Within the Limits of Reason Alone, especially in the third book entitled "The Victory of the Good over the Evil Principle, and the Founding of a Kingdom of God on Earth." Here, he distinguished between ecclesiastical faith (the Christian Church as it has developed historically) and pure religious faith (which is not to be identified absolutely with ecclesiastical faith even though ecclesiastical faith is its vehicle). He writes:

In men's striving towards an ethical commonwealth, ecclesiastical faith thus naturally precedes pure religious faith: temples (buildings consecrated to the public worship of God) were before churches (meeting-places for the instruction and quickening of moral disposition). . . Since, then, it remains true once for all that a statutory ecclesiastical faith is associated with pure religious faith as its vehicle and as the means of public union of men for its promotion, one must grant that the preservation of pure religious faith unchanged, its propagation in the same form everywhere, and even a respect for the revelation assumed therein, can hardly be provided for adequately through tradition, but only through scripture; which, again, as a revelation to contemporaries and posterity, must itself be an object of esteem, for the necessities of men require this in order that they may be sure of their duty in divine service. 16

Ecclesiastical faith is important, as Kant indicates above, yet such faith is never to be considered as the absolute expression of pure religious faith. That kind of faith can only exist in the realm of spirit or idea. When ecclesiastical faith considers itself as pure religious faith absolutely, the result is that "he who refuses to acknowledge its (peculiar) ecclesiastical faith is called by it an unbeliever and is

${ }^{16}$ Immanuel Kant, Religion Within The Limits of Reason Alone trans. by Theodore Greene and Hoyt H. Huds on (New York: Harper \& Row Publishers, 1960), p. 97. 
hated wholeheartedly."17 Thus, according to Kant, the truiy important faith is that which strives after pure religious faith, and the end of such a faith is the moral betterment of the individual. On this, Kant writes:

For the final purpose even of reading these Holy Scriptures, or of investigating their content, is to make men better; the historical element, which contributes nothing to this end, is something which is in itself quite indifferent, and we can do with it what we like. (Historical faith "is dead being alone", that is, of itself, regarded as a creed, it contains nothing, and leads to nothing, which could have any moral value for us.) $)^{18}$

Not only does Kant subordinate the historic expression of ecclesiastical religions to pure religious faith, he also declares that they are ultimately fated to pass away as pure religious faith takes its place. This exchange was already on its way, according to Kant, because of the moral disposition which was already emerging in western civilization. Soon, he wrote:

Religion will gradually be freed from all empirical determining grounds and from all statutes which rest on history and which through the agency of ecclesiastical faith provisionally unite men for the requirements of the good; and thus at last the pure religion of reason will rule over all, "so that God may be all in all."19

The above quote indicates the great separation between faith and history which rationalism produced. The process began with the elevation of reason as the sole criterion of truth and ultimately resulted in the elevation of idea over manifestation, even to the extent that historical details were considered as only the dispensable shell of reality. Thus, the meaning of historical events was made independent of its actual

$$
\begin{aligned}
& \text { 17I. Kant, Religion..., p. } 98 . \\
& \text { 18I. Kant, Religion...., p. } 102 . \\
& \text { 19I. Kant, Religion. ..., p. } 112 .
\end{aligned}
$$


historical context. This was the state of philosophical affairs when the French Revolution broke out. The Revolution was, in many ways, the result of rationalism itself, for the Enlightenment had put a premium on man's reason and on his ability to rightly order his affairs. The Revolution itself proposed initially to be the reordering of society upon rational grounds. It was to be the dawning of a new world where political freedom would compliment the already growing intellectual freedom brought about through the Enlightenment. Because of this connection, a brief description of the progress of the Revolution, especially as it affected Germany, is in order here.

'THE POLITICAL CATALYST: THE FRENCH REVOLUTION

When the Revolution broke out in France on July 14, 1789, the Germans responded ambivalently; some enthusiastically welcoming the Revolution as if it were their own, others watching the event from afar as intellectual spectators. In general, European intellectuals tended to view the Revolution positively as the natural outcome of the Enlightenment and the first step towards a truly enlightened world. It was in this spirit that Hegel and Schelling, while still students at rübingen, planted a tree of liberty in honor of the Revolution. Yet this enthusiasm was not at all a show of pro-French sentiment, but a recognition and approval of the principles at the base of the Revolution. German intellectuals hoped for an application of Enlightenment principles in their own countries, though not necessarily through the same means. Thus, J. G. Herder remarked: "We can watch the French Revolution as we watch a shipwreck at sea from the safety of the shore," and historian Johannes 
Müller who had hailed the coming of the Revolution in 1789 as "the most wonderful day since the decline of the Roman Empire" also said, "heaven forbid that similar revolutions occur in other lands."20 When the Revolution changed direction in 1792 and began to direct itself outward militarily, many German intellectuals resisted it vigorously. Later, their disappointment turned to disillusionment as Napoleon, taking advantage of the political confusion in France, launched a major campaign for a Erench European empire.

Germany's chief monarchs, Austrian king and Holy Roman Emperor Leopold II and Frederick William I, king of Prussia manifested a careless attitude toward the events in France. If they could have seen ahead, they would have reason for concern, yet from their vantage point in 1789, they had little to fear. In the first place, Germany did not share the same social conditions as France, which might have caused internal problems. Eighteenth century German society was very rigidly stratified, and social divisions were generally accepted and observed. The monarchy held a strong position and wielded absolute authority. Further, Germany was not at all unified, but was divided up into no less than 1,789 independent sovereign powers. The lack of social mobility in Germany, along with its torn condition (Zerrisenheit) and overall provincialism combined to create a static and strongly conservative attitude within Germany as a whole. In addition, the philosophic tradition in Germany was less mundane than in France, and more concerned with the internal development of individuals (Bildung) than in the reorganization

20 Koppel S. Pinson, Modern Germany: Its History and Civilization 2nd ed. (New York: The Macmillan Company, 1966), p. 28. 
of the state of society. German intellectuals were much too dependent upon court patronage to either want or attempt the destruction of a social order which benefited them. Ironically, it was some of these very factors in German society which now prevented the outbreak of revolution in Germany, that later mobilized effective German resistance to French invasion under Napoleon.

A second reason why the chlef monarchs of Germany did not become concerned with the Revolution, was their own engagement in other pol1tical affairs. When the Revolution came, Leopold II was involved in a war with the Turks which was costing him greatly in both men and money. Although as king of Austria he had an alliance with France, he was, at the time, much more interested in stimulating the Austrian economy and thus swelling the Austrian treasury, than in striking out on a political crusade against a nation which seemed too disorganized either to assist or injure. Similarly, Frederick William I was too preoccupied with internal problems of bankruptcy and administrative chaos in his own kingdom to be concerned about the domestic affairs of France. In fact, Frederick may well have felt favorably inclined towards the Revolution since it could potentlally upset the Franco-Austrian alliance and thus strengthen his position in Germany. 21 Not only were Leopold and Frederick jealously suspicious of one another, but both were anxiously watching Catherine of Russia lest she attempt to annex all or part of Poland. In sum, the attitude of Germany to the Freach Revolution was, at best, passive interest. The German philosophes, in general, welcomed the Revolution initially as their own, though they did not wish something

21 Sydney Seymour Biro, The German Policy of Revolutionary France Vol I (Cambridge, Mass .: Harvard University Press, 1957), p. 36. 
like it to befall Germany, and the major German monarchs simply watched and observed, seeing that it was within their interests to stay out of 1t. Had they rightly understood the powerful ideological forces behind the Revolution, they would have had cause for alarm, for the French Revolution was not simply the end of another dynasty in France, to be replaced by another, nor was it essentially some visionary grasp at utopia. It was the signal for the advent of a new world order in which privilege and tradition would be destroyed or at least strictly confined. No area of human concern was to be exempt, kings were executed, churches were pillaged and abandoned or turned into shrines to Reason. It spelled the death of absolute authority and divine-right, and it certainly could not be confined to the borders of France.

The events that brought Prussia and Austria into conflict with the revolutionary forces are complicated. No single event can be pointed to as predominant, neither can France, Prussia, or Austria be held solely at fault. From the French revolutionary perspective, it looked as if Germany was gearing up for a strong anti-revolutionary war which would re-establish the forces of conservatism. On the other hand, from the German perspective, it looked as though the French revolutionaries were intent on extending the Revolution to Germany itself, especially in German holdings in the Alsace regions on the Rhine River.

The mutual suspicions of all powers concerned, seemed to be born out of the increasing French emigre population gathering on German soll. Since July 14, 1789 and even before, a steady stream of nobles had been emigrating from France. Colonne, former Controller General, was driven from France in 1787 to become the first of many emigres and Artois, brother of Louis XVI and arch enemy of the Revolution, was ordered into 
exile shortly after the recall of Necker in July of 1789. In July and August of 1789, during the great fear in the countryside, and also later In 1791 with the failure of the flight to Varennes, the ranks of the emigres began to swell until there were twenty thousand at Coblenz alone. It was Coblenz, a Rhenish town, dependent on the Archbishop (elector) of Trier, that became the chief center of emigre concentration and the headquarters for Artois and his retinue, but the emigres were intriguing with most of the courts of Europe.22 After unsuccessfully trying to stir up an armed revolt within France in order to restore the Ancien Regime, the emigres began to mobilize their forces for an armed invasion of France.

The fact of a French emigre population mobilizing for an invasion into France against the Revolution, quite naturally caused the revolutionaries great concern, but concern turned to alarm when it was rumored that the King and Queen themselves were in communication with the emigre forces and were working hand in hand with them to effect the invasion. 23 As this rumor spread, the King and Queen were increasingly eyed with suspicion. It was in fear for their lives that they made that desperate and tragically unsuccessful flight for Varennes on June 20, 1791.

By this time, events were happening in Germany and France which

22 Crane Brinton, A Decade of Revolution, p. 57.

23 This rumor was only half true, for although Louis was in communication with the emigre forces, and did make a plea for armed intervention by a congress of European powers, he had clearly refused to countenance the emigres plans of invasion on the grounds that it would probably result in civil war and further endanger his and the queen's safety. See M. J. Sydenham, The French Revolution (New York: Capricorn Books, 1966), p. 92 . 
brought the two powers closer and closer towards conflict. Shortly before Varennes, Leopold became genuinely concerned with what was happenIng in France especially as these events jeopardized the royal family. In May of 1791, Leopold met with emigre leader Artois and on July 6th of that year, issued the Padua circular which invited the kings of other German states to join him "In vindicating the honor and liberty of Louis XVI and his family, and in putting limits upon the perilous extremes to which the Revolution was tending in France." In August of 1791, Leopold and Frederick William met at Pillnitz to discuss their policy regarding France and the emigres. The result was the Declaration of Pilinitz which rejected the emigres demand for immediate intervention and further refused their requests to use Germany as an asylum for warlike preparations against France, but also stated positively that the position of the French monarch was a matter of concern to all European soverelgns, and threatened war if the feudal rights of German princes in the Alsace were not restored.

The Declaration of Pillnitz was ill-timed, if indeed its purpose was to terrify France by threats, for it had the opposite effect. The rumored appeals of the royal family for foreign intervention, the flight for Varennes, the intrigue of emigres:and the protection afforded them by German princes on the very doorstep of France, all combined with the Declaration to impress upon the French people the feeling that the foreigner was awaiting only an opportunity to pounce upon France. The prevalence of this feeling in France marked the end of that early idealism of 1790 when the National Assembly had renounced all wars of conquest and declared that France would never take up arms against the liberty of any people. Under the leadership of Brissot, the Revolution took a 
decisive turn towards a more aggressive foreign policy. War was looked upon as beneficial and necessary to the Revolution by Brissot and his supporters. 24

Events progressed quickly in France during the latter part of 1791 to bring the conflict ever closer until finally on January 24,1792 , the Legislative Assembly issued an ultimatum to Emperor Leopold, Giving him until March 1st to renounce all agreements directed against French sovereignty, independence, and security. At this point, a clash was inevitable, and Austria and Prussia drew close together in preparation for joint action against France'. On February 7, 1792, they signed an alliance of friendship and defense which provided for reciprocal aid in defense against attack from whatever quarter (perhaps from Russia) it might come, and the grant of 20,000 men upon demand. In the midst of the worsening situation, Leopold died and was succeeded by the more bellicose Francis II, while in France, Delessart was dismissed by the National Assembly and replaced by the girondist sympathizer Dumouriez. Finally, on April 20th, Dumouriez stood before the Legislative Assembly and called for war on Austria. After deliberating for some time over Dumouriez' proposal, the Assembly voted on war and sent a deputation to get the king's signature on the formal declaration. Germany was now formally at war with the Revolutionary forces in France.

With the outbreak of the War of the First Coalition, we come to a break point in the history of this period. By 1792, the French Revolution, as it had originally been concelved, was passing away. Whatever cosmopolitan ideas had been present at its inception wesopidy

24 M. J. Sydenham, The French Revolution, p. 91-92. 
becoming submerged to French nationalistic aims which later, under Napoleon, becane imperialistic and dynastic aims. The effects of this eclipse of Enlightenment ideals were to have profound repercussions in Germany in the realms of politics and culture.

The German struggle against France helped to engender the nationalistic sentiments of Germans, but it also succeeded in demonstrating the basic weakness of Germany and of its divided condition. Prussia joined the first coalition against France in 1792, and had fought alongside Austria but after suffering defeats at Valmy and Jemappes, she concluded a separate peace settlement with France in 1795 and then concerned herself with the east. Austria continued to struggle against France until 1797 when she came to terms in the treaty of Campo Formio. Under the terms of this treaty the entire left bank of the Rhine was ceded to France.

Napoleon's strategy in Germany consisted in playing off Austria against Prussia and in encouraging the smaller German principalities against both kingdoms. The jealously between the various kingdoms and principalities of Germany allowed him to do this with great success. Napoleon also eliminated many of the smaller principalities and raised some states to the status of kingdoms. Ironically, it was through his efforts that Germany was to take its first step towards unification.. On July 17, 1806 he created the Confederation on the Rhine, a virtual "third Germany", which was made up of Bavaria, Wüttemberg, Baden, HesseDarmstadt (and later Saxony), and twelve smaller states. As Napoleon pushed into Germany, Prussia once again entered the war against France but was terribly beaten by Napoleon's forces at Jena on October 14, 1806. 
From the defeat at Jena in 1806 until Napoleon's defeat in 1814 , Prussia began to reorganize and rebuild for the future. The dynamic of the reforms, which were social, economic; administrative and municiple, was provided by a growing sense of individuality and uniqueness among Germans, especially Prussians. It was the disillusionment of the early Revolution, combined with the humiliation of the Napoleonic period which generated the cultural forces of the nineteenth century.

\section{THE CULTURAL RESPONSE: ROMANTICISM AND HISTORICISM}

Although, at the time, the Napoleonic invasions into Germany were difficult and humiliating, it was out of this humiliation that Germany emerged as a nation. In fact, Germany derived great benefit from the French Revolution and Napoleonic invasions. First, on the practical level, the Napoleonic invasions and consolidations in the Rhineland marked the first step toward.German unity. After the Congress of Vienna, in 1815. the territory of what had been the Holy Roman Empire remained almost the same, but now instead of a vast number of small and petty principalities, there was a confederation of thirty-nine states under as many monarchs. Although Germany was still far from being a unified nation, this reorganization greatly facilitated later unification. Second, the French Revolution convinced many German statesmen and intellectuals that if there was not to be a repeat of foreign incursions into German territory then unification must take place to present a unified policy and resistance. In addition, it was felt that the German states should apply more democratic principles within their governments and not simply return to eighteenth century autocracy. This latter point was of 
of extreme importance (and a later frustration) to German intellectuals. Heine, for example, mocked the tendency of restoration German monarchs to fall back into the eighteenth century mode of rule. He wrote:

When I was at the top of the St. Gotthard Pass, I heard Germany snoring. . . She slept peacefully, under the protection of her thirty-six monarchs. In those days, crowns sat firmly on the prince's heads, and at night they just drew their night caps over them, while the people slept peacefully at their feet.25

These factors combined to radically change German culture and society in the nineteenth century. Although these changes can be seen in many aspects of German society (i.e. political, artistic, Iiterary) the present discussion will focus on two general cultural movements which were intimately related: Romanticism and Historicism.

\section{$\underline{\text { Romanticism }}$}

As earlier indicated, the outbreak of the French Revolution was looked upon favorably by intellectuals all over Europe. The reason for this early favorable reaction was the sense of community that European intellectuals shared during the Enlightenment period. The Enlightenment had looked forward to a progressively better world for mankind, indeed a cosmopolis, where the divisions and differenees of nations would be resc solved by Reason. This general expectation was founded upon the belief in a natural law common to all men regardless of national or cultural origin. According to Brinton, "The Enlightenment promised heaven on earth, soon, and by a process that meant for the individual, a "natural" release of expansion, appetitive forces within himself, not self-denial

25Frederick B. Artz Reaction and Revolution (New York: Harper and Brothers Publishers, 1934), p. 137 . 
and inner discipline."26 Although Brinton's characterization of the Enlightenment may only apply to 1ts extreme form, nevertheless, it does embody the essential message of the Enlightenment: that western culture is on its way up and Reason shall lead the way. It was in such a belief that Condorcet wrote these lines during the early phase of the Revolution:

Everything tells us that we have come to one of the great revolutions of the human race. What is more suitable for enlightening us as to what we should expect from that revolution, for providing us with a sure guide in the midst of these movements, than an account of revolutions which proceeded and prepared this one? The actual state of human enlightenment guarantees to us that this revolution will be a happy one.27

But as has been indicated above, something went wrong, and the euphoric atmosphere of the early revolution turned into the nightmare of the Reign of Terror, Napoleon and bitter and bloody wars. It seemed as if the Bnlightenment dream was shattered, the hope of a great European cosmopolis dead. After the fallure of the revolution, there were degrees of reaction to Enlightenment 1deas. In Germany, the catalyst for the anti-Enlightenment reaction was the loss of the cosmopolitan character and the early politicization of the French Revolution.

The first stirrings of the Romantic Revolt against the Enlightenment in Germany, came in liturature and generally from authors and poets who had, before the Revolution, been committed to its principles. The conversion from rational to romantic sentiments came via the later Revolution; as Artz writes:

The precursors of German romanticism had been prophets of an ideal of boundless liberty. No rules should bind the genius

26 Crane Brinton, The Shaping of Modern Thought (Englewoods Cliffs, New Jersey: Prentice Hall Inc., 1963), p. 138.

27Quoted in Brinton, The Shaping of Modern Thought, p. 139. 
because the divine spirit spoke in him. But before the end of the Napoleonic wars, nearly all the chief poets, critics, and novelists of the movement had passed into a mood of the blackest reaction. 28

Novalis, the reputed founder of German romanticism, had been an ardent revolutionary and had once expressed his longing for a "new massacre of St. Bartholomew, a wholesale destruction of despotism and prisons."29 The transition from rationalism to romanticism in Germany is nowhere seen so dramatically as it is in Novalis. By 1799, particularly in his Christenheit oder Europa, he was not only proclaiming the Prussian king to be God's gift to humanity but also defending the temporal power of the Papacy. In this work, according to Artz, Novalis:

attacked the Enlightenment for its mechanistic and utilitarian view of the state and its ideals of natural rights, social equality, and political democracy. In the course of the argument, he extolled the spirit of Jesuitism and declared it a misfortune that the Papacy no Ionger had the power to stop such dangerous theories as those of Copernicus. 30

Novalis can serve as the paradigmatic model for a general movement which swept over Europe, and especially Germany, in the post-Napoleonic period. The same pattern is seen in other German literary figures such as Schlegel, an early rationalist, cosmopolitan, and classicist, who "under the influence of Ficte and Schleiermacher, and under the impressions of the French Revolution. . took a deep bath of romanticism wherein he rid himself of all taint of Jacobinism." 31

Although the Romantic Revolt in Germany first expressed itself in

28 Frederick B. Artz, Reaction and Revolution, pp. 57-58.

29Frederick B. Artz, Reaction and Revolution, p. 59.

30 Frederick B. Artz, Reaction and Revolution, p. 58.

31 Frederick B. Artz, Reaction and Revolution, p. 59. 
Iiterature and poetry, events within Gernany soon combined to produce a particular brand of romanticism not manifested in any other country. These events were all tied to the German problem of disunity and thus, while literary romanticism longed to find the German soul, a special brand of political romanticism quested for a unified German nation. Both of these factors combined to produce the revolutionary political and cultural forces in nineteenth century Germany, as Iggers has indicated:

The Ifterary revival in Germany in the late eighteenth century involved the attempt to free national literature from the influence of French neo-classic patterns, and was far more conscious than the romantic stirrings elsewhere. But, most important, German political nationalism arose in the struggle against the French domination of Germany in the aftermath of the French Revolution and the Napoleonic victories, a struggle which intensified the anti-Enlightenment bias of German political thought. 32

It was this combination of strong German cultural awareness mingled with the humiliation of the Napoleonic wars that made the ant1-Enlightenment reaction in Germany so unique.

German romanticism tends to elude. description because it was not so much a system, as a state of mind or a new Weltanschauung. Altholz' claim that "It is as impossible to define romanticism as it is to ignore $1 t^{\prime \prime}, 33$ is probably correct for $1 t$ was the very essence of romanticism to consider all of life in all its varlety, to merely take the given as such and to embrace it as the fullness of life. Welch gives the following historical definition of romanticism:

32 George Igger, The German Conception of H1stary (Connect1cut: Wesleyan University Press, 1968), p. 7 .

33 Josef L. Altholz, The Churches in the Nineteenth Century

(New York: The Bobbs-Merrill Company, Inc., 1967), p. 49. 
Here we mean above all the movement beginning in Germany in the $1790^{\prime} \mathrm{s}$ which gave itself this name. Some of the ideas of this movement had been announced in Rousseau and Lessing; for its nurture Herder and Schiller, along with the Sturm and Drang movement, were of special importance; it came to full flower in Iiturature and as a Weltanschauung in Novalis and the Schlegels (especially Friedrich Schlegel), Schleiermacher, and Fichte, Görres and Adam Müller, Tieck and Wachenroder. Schlelermacher's Speeches and Sollloguies have been called its two chief mani-festos in the realm of religion, but this romanticism. iwas also of importance for theology in Hegel and Schelling. 34

Because fomanticism is so systematically amorphous and covers such a long and diverse historical duration, the best approach is to give general characteristics of this movement.

Paul Tillich, in a lecture series delivered at the Divinity School of the University of Chicago, has given some general characteristics of the Romantic Revolt which are not only intellectually penetrating, but also highly appropriate to this discussion, therefore, the following treatment of German Bomanticism will follow his categories.35 The first characteristic of Romanticism, according to Tillich, has to do with the relationship between the Infinite and finite which is actually the question of the relation between Absolutes and particulars or ideas and history. Here, Romanticism is presented as a movement aiming at a balance between the Infinite and finite. Romanticism is a reaction against the Enlightenment tendency to secularize human affairs, against the tendency to see reality as operating mechanistically, but it is an over-reaction because It ultimately breaks the balance it aims at. Thus, Tillich says:

${ }^{34}$ Claude Welch Protestant Thought in the Nineteenth Century Vol. 1 , 1799-1870 (New Haven: Yale University Press, 1972), p. 52.

. 35Paul Tillich, Perspectives on 19th and 20th Century Protestant Theology ed., Carl E. Braaten (New Yorki Harper and Row Publishers, 1967), pp. 76-90. 
We have here then the breaking through of the infinite against the balance it had in the classical criticism or negation of the Enlightenment, the romantic breakthrough of the balance into the horizontal line. 36

Just what T1Ilich means here by "the romantic breakthrough of the balance into the horizontal line," is helpful in understanding German history subsequent to the Romantic Revolt. It is when the particular romantic conception of the balance, which is characterized as ironic, is applied to the individual form of culture that the problems arise. Irony, within the context of the romantic balance, means,

that the Infinite is superior to any finite concretion and drives beyond to another finite concretion. The ego of the romanticist. . Is free from bondage to the concrete situation. A concrete situation means both the spiritual situation, a concrete form of falth, and the situation in relation to human belings. - .romanticism drives beyond any particular actualization of the Infinite in a finite situation. 37

It was the irony within the romantic balance of the Infinite and finite which set the stage for the break between right and left-wing Hegelians later. There are two possible responses to the notion that form is unimportant. Either one seeks meaning in the vague realm of the completely transcendent, thus Ignoring form and succumbing to acosmism; or one accepts the relativity of form and attempts to live within it, thus giving up the possibility of absolute knowledge and at worst succumbing to atheism. Romanticism carried within it this potential gulf between form and content which has since remained a problem for theological science even unto the present. In nineteenth century Germany, this chasm had a sociological, as well as an intellectual, effect. Tillich goes on to say:

36 Paul Tillich, Perspectives.... p. 82.

37 Paul Tillich, Perspectives.... p. 89. 
Now this romantic irony breaks through the sociological forms, for instance, the traditional Lutheran paternalism, the idea of the family, the relation of parents to children, the political stablilty, etc. All these forms now became questionable. Every special content in the traditions of the European countries became a matter of "yes" and "no." Irony does not mean simply an attacks there is a "yes" in 1t, but the "no" is predominant. It always says "no" as vell to a concrete solution to life's problems. 38

As the tension between form and content became increasingly difficult for early romantic thinkers, many began to turn to the authority of the State and the Church, to provide some sort of absolute direction. It is within this context that the growth of the German nation (and the resurgence of ultramontanism) in the nineteenth century is to be understood. The State increasingly took over the functions which the sense of God had previously fulfilled until the State became everything in Marxist theory. Secularism received, in the nineteenth century, its most powerful impulse. Those who had relinquished the hope of transcendent meaning looked to the State to provide that meaning. In the same way, those who despaired of finding any content within the form of history, but who were unwilling to accept the full consequences, found their transcendent meaning within the dogma of the Catholic Church and the Pope. Important here is the work Du Pape (1819) by Joseph de Malstre in which the Church was presented as the only universal hope for man. Both Novalis and Schlegel resorted to the Catholic Church and early became converts. Zacharias Werner, whom Artz calls "the most extreme and fantastic of the German romantics," and who was a great devotee of Jean Jacques Rousseau, not only became a Catholic convert but later entered the priesthood.39 The Lutheran church also experienced a very conservative revival which was

38Paul T1ll1ch, Perspectives.... p. 89.

39Frederick B. Artz, Reaction and Revolution, p. 60. 
extremely confessional and emphasized discipline, sacraments and doctrine. The most famous of these confessional groups was centered at Erlangen and became known as the Erlangen school. This school, while definitely conservative, was still responsive to critical scholarship and sought to come to grips with the problem of the relation between the finite and infinite in the person of Jesus, and thus it advanced the kenotic theory of Jesus' person to explain both his humanity and divinity. In general, the political reaction was the result of over-all conservative mood in Europe, as was the religious reaction. In fact, these two areas worked together to promote the Romantic Revolt as Altholz remarks,

The conservative Lutheran revival, though not of Pietist origin, drew strength from movements of religious awakening among the people. On the other hand, conservative Luthernism was Iinked to the court-centered reaction after 1848 by the jurist F. J. Stahl, a convert from Judaism. With its emphasis on authority and church order, the Lutheran revival. showed marked affinities with both Roman Catholicism and High Church Anglicanism. 40

In sum, the first, and probably the most important characteristic of Romanticism was its tension-filled balance between the infinite and finite which increasingly tended towards the infinite and was, thus, always in danger of sacrificing form to content. When the romantic synthesis pulled apart, there was a mad scramble for universal certainty, which some found in the State while others in the Church. Seen in this perspective, the romantic synthesis and its failure gave birth to nineteenth century German movements such as nationalism, historicism, secularism, and materialism, as well as an over-all fragmentation within German society.

A second characteristic of German Romanticism which Tillich notes 40Josef I. Altholz, The Churches in the Nineteenth Century, p. 107. 
is that aspect of Romanticism which is most readily associated with it, 1.e. the emotional and aesthetic element. The emotionalism of Romanticism is not to be identified so much with the actual expression of human emotions as it is with the intultive awareness of the infinite within the finite. Thus, this characteristic is closely tied up with the romantic balance between the infinite and finite. Romanticism aimed at understanding life in a wholistic way. It did not seek to debase the moral imperative in man nor, on the other hand, the scientific consideration in nature but rather in considering both these things asked the question: "Is there something in nature which, so to speak, fulfills the commands of the moral imperative and transcends the mere scientific analysis of nature?"041 This particular characteristic of Romanticism is probably the most visible of any, it is this characteristic of the romantic Weltanschauung which breaks through in almost every aspect of IIfe, for example in art and music. In art, the epitomic neo-classical works of David give way to the romantic works of Gericault and Delairoix, while in music, the balanced resolute structure of Haydn's chamber music gives way to the increasing open style of Beethoven. Within each of these examples is an underlying thirst for 11fe, an overall desire for total Imnersion in Iife which leads to the awareness of awe before the universe. Novalis wrote, "The romantic studies IIfe as the painter, the musician and engineer study coloux, sound and power. It is a careful study of Iife which is the making of the romantic. 042 The Bomantic Revoltralionad aiprofound impact: on theology as can be seen in the works of Schelling,

$$
\begin{aligned}
& 41_{\text {Paul Tillich, Perspectives..., p. } 83 .} \\
& 42_{\text {Karl Barth, Nineteenth Century Theology, p. } 349 .}
\end{aligned}
$$


Schleiermacher, and also Hegel, but this point will be taken up in considering their impact on Baur's theological development.

The third and final characteristic of Romanticism to be considered here, has to do with the romantic conception of the past and its considered valuation of tradition. According to Tillich "here the conflict with Enlightenment was especially great. 043 The Enlightenment attitude towards history was not particularly negative, but it did not highly value the past. The past was always seen and evaluated in reference to the present. A good example of this attitude is G. E. Iessing's Education of the Human Race, which portrayed world history as the gradual awakening or enlightenment of mankind. The past was not valued at all on its own terms or for 1ts own sake, rather it was considered disposable, an archaic stage in man's development which he had outgrown. The Enlightenment concept of history was a naive mechanistic view which pictured man as almost outside of history by virtue of his reason. Thus, he could evaluate history from a superior vantage point and pass judgment on it by virtue of his more absolute understanding.

Romanticism utterly demolished this naive conception of history and ultimately succeeded in placing man back into the historic process. The realization of the infinite within the findte, noted lobove, caused the romantic to look for the infinite within past historlcal individuals, and thus to understand historical epochs on their own terms. The past was considered to have revelatory significance itself. The Enlightenment mechanistic conception of history began to give way to a new organic concept which fully appreclated and revelled in the complete variety' in

${ }^{43}$ Paul Tillich, Perspectives.... p. 83. 
history. For Novalis, the theme of history was "process and everincreasing unfoldings, $" 44$ and no aspect of this unfolding was entirely separate from the whole. History was conceived of as a great organism or plant which grew and developed through different stages, but was always straining toward the complete realization of its original idea. But Romanticism did not maintain the same sense of cosmopolitanism that had characterized the Enlightenment, for different nations were Iike separate plants growing and realizing distinct ideas. In this regard, the French Revolution and Napoleonic Wars were a great check on a cosmopolitanism which might have produced a sense of universal history. Instead, what increasingly emerged in nineteenth century historiography were national histories developed around an idea which was considered the original idea of that nation. Janosi writes:

The romantics believed that each organism had its own life, distinct from that of its parts; that it developed and at times changed unconsciously; that it underwent influences and exerted its own influence, though the active aspects were less stressed by the romantics in accordance with the Goethian parallel of plant life.45

\section{Historicism}

The romantic conception of history had profound implications for historiography and the growth of the Historicist Movement in Germany. In this regard, the name Johann Gottfried von Herder is particularly Important for it was he who first laid down many of the theoretical conceptions of Historicism. Herder is a transitionary figure who bridges

44 Friedrich Engel Janosi, The Growth of German Historicism in John's Hopkins University Studies in Historical and Political Science, Serfes $62,1944, \mathrm{p} .39$.

45Friedrich Engel Janosi, The Growth of German Historicism, p. 40. 
the Enlightenment and Romantic periods for although he adheres to the concept of individuality among all historical phenomena, although he rejoices in the variety and plurality of history, he maintains connections with the Enlightenment in his bellef that man is still capable of grasping the essence of this historical variety. 46 Thus, for Herder, the historian still stands somewhat outside of history, he still remains the subjective observer. As Romanticism progressed, less and less confidence was placed in man's subjective point of reference, as the idea of the historicity of all existence gradually dawned on historians.

Even in some of Herder's earliest work, he established his concept of the Humanitätsideal, an idea which, according to Igger, stressed that "every age must be viewed in terms of its oun immediate values; that there is no progress or decline in histary, only virtue filled diversity. 04 ? Herder's Enlightenment roots are evident in his interest in universal history and in his cosmopolitan conception of all cultures even though outwardly diverse. For Herder there is, within the diversity, a meaningful process which is guided by the sovereign God. Igger says of him:

The Historicism of Herder rests upon the firm belief that there is a Divine purpose in history, that "Providence guides the path of development onward". All of nature and of history reflect God. Herder compares history to a stream rushing to the ocean or to a growing tree. History is indeed meaningful, the scene of a guiding intention on earth, although we do not perceive this ultimate purpose at once. Basically, mankind is still one, according to Herder, however the meaning of history is not found in the direction of events toward a rational end but in the multiplicity of ways in which the human mind expresses itself in the diversity of nations. 48

46 Friedrich Engel Janos1, The Growth of German Historicism, p. 42. ${ }^{47}$ George Igger, The German Conception of Histary, p. 30.

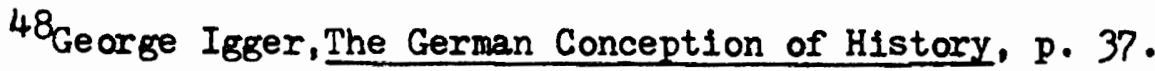


Thus, Herder's work is an Important first step towards a new conception of history but falls short of the true romantic conception of history which was even more individualistic. It was Herder's ideas through the crucible of the French Revolution and Napoleonic wars which produced the historicist tradition in Germany in the nineteenth century. As Lord Acton once wrote, "Historical writing was old, but historical thinking was new in Germany when it sprang from the shock of the French Revolution."49 George Igger has provided a convenient summary of the effects of the Revolution on German society, and on German historical thinking. His three points follow the chronological stages of the development of German Historicism.

1. The Enlightenment faith in universally applicable ethical and political values, which had been already challenged before the Revolution, was now completely shattered. . German educated opinion now agreed that all values and rights were of historic and national origin and that alien institutions could not be transplanted to German soll.

2. The concept of the nation had changed fundamentally. (States and cultures were no longer viewed as all contributing equally to a world garden). Nationalism no longer united, it divided. 3. Finally, the State occupies a very different role. Fichte, who had written in 17\%, that "the aim of all government" is "to make government superfluous", wrote in 1807 that "there is neither law nor right except the law of the stronger".50

The Romantic Movement reacted against the extreme rationalism of the Enlightenment and sought to strike a balance between the infinite and finite within human history. Herder appears to have attempted just this, to retain a sense of cosmopolitanism while at the same time giving serious consideration to the tremendous individuality of history. This could only be done as long as an adequate synthetic model existed to 49Quoted in Janosi, The Growth of German Historicism, p. 39.

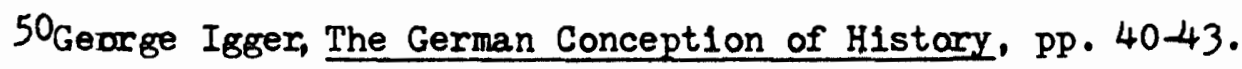


deal with the tension. But as Tilifch has indicated, the ironic nature of the romantic synthesis was not adequate to hold the two elements together. Although initially Romanticism said both "yes" and "no" to historical situations, the "no" became increasingly predominant. With the breakdown of the romantic synthesis, came the utter relativization of the form of culture and consequently the utter transcendentalization of its content into the mystical unconsciousness. The form of history Increasingly became the only concern of historiography, while speculation as to its meaning was avoided or relegated to philosophy or theology. It was out of these events that the modern discipline of history emerged.

No one is more important in this regard than Leopold von Ranke whom Fritz Stern has called "the father as well as the master of modern historical scholarship."51 Ranke was not at all concerned with judging the past or instructing the present, but rather with history itself. His concern for the form of history did not arise out of a belief that history was meaningless, and that, therefore, all that remains for the historian are particulars. Ranke belfeved that there was a meaning to histary. But what Ranke objected to was the method of Imposing upon history some speculative scheme which only succeeded in distorting historical facts and preventing a true understanding of historical epochs. His method of writing history consisted of a twofold approach; first, gather, establish and analyze the facts, and second, search among the facts for trends to uncover the unity of the historical epoch and bring the facts together into a synthesis. The aim of his method was

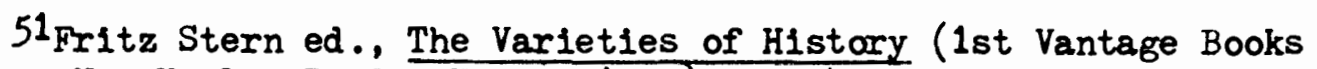
Edition; New York: Rand om House, 1973), p. 54. 
simply to write history as it had actually happened. If the historian does his work well, according to Ranke, "while he reflects on the partioular, the development of the world in general will become apparent to him."52 Thus, what was unique in Ranke was his resolution to start with the facts of history rather than with a speculative model. Whatever the meaning of history might be, it was ultimately to be found in the facts themselves and not in speculative concepts. Ranke carried his rejection of speculation in historlography one step further by not only rejecting the application of human speculative systems upon historical events but also rejecting any notion of a divine guiding hand behind the events of histary, 1.e. determinism. For him, history was the realm of becoming, produced out of the free interchange of historical individuals in proxim1ty with one another. Thus, history (1.e. the facts) is sufficient to explain history (1.e. the meaning). He wrote:

We must concede that history can never possess the unity of a philosophical system, but it does have and inner connection of its own. We see before us a series of events which follow one another. If I say "conditioned". I certainly do not mean conditioned through absolute necessity. The important point is rather that human freedom makes its appearance everywhere, and the greatest attraction of history lies in the fact that it deals with the scenes of this freedom.53

Ranke himself can be characterized as a transitionary figure because he still holds onto the Enlightenment confidence in man's ability to know the past as it actually happened. In later historicism not only is history sufficient to explain history; history is now sufficient to explain

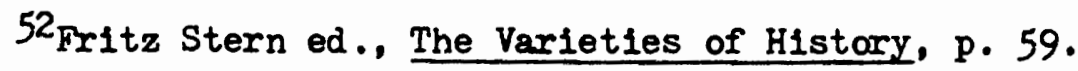

53Fritz Stern ed., The Varieties of History, p. 60. 
the historian. 54

\section{SUMMARY}

The nineteenth century in Germany was a complicated time of upheaval which marks the birth of modern Germany. The French Revolution was the catalyst whereby a growing German cultural consciousness, was transformed into an intense German national consciousness.

The philosophical preparation for the Romantic Revolt had been prepared earlier by Kant in his separation of faith and history into the realms of the noumenal and phenomenal. Here, the particulars of history suffered, as discussed earlier. The Napoleonic wars also helped to give birth to the Romantic Revolt in Germany by disillusioning many German intellectuals concerning the viability of such Enlightenment ideas as

${ }^{54}$ Later historicism, reacting against the positivistic theories of August Comte and J.S. Mill, insisted on an even more radical conception of the historicity of man. The name of Wilhelm Dilthey is here important. For him, history demands its own methods of conduct since historical knowledge differs in essence from scientific knowledge. He writes: All knowledge is knowledge of experience; but the original unity of all experience and its resulting validity are conditioned by the factors which mold the consciousness within which it arises, i.e. by the whole of our nature. This standpoint, which consistently realizes the impossibility of going behind these conditions, of seeing as it were without an eye or directing the gaze of knowledge behind the eye itself, I call the epistemological standpoint; modern knowledge can recognize no other. Quoted in C. G. Rand, "Two Meanings of Historicism in the Writings of Dilthey, Troeltsch, and Meinecke", Journal of the History of Ideas, 25 (Oct.-Dec., 1964), p. 507. This was a later development in historicism and was not a consuming problem for Baur, yet it does raise problems for his proposed evaluation of the historical Jesus as well as the Church. Baur's treatment of the N. T. documents, for example, indicates that he believed in the possibility of writing history as it actually happened, in the same way that Ranke did, thus he does treat these sources naively. The more difficult theological problems raised by Dilthey provided the grist for the work of Ernst Troeltsch, in his The Absoluteness of Christianity and the History of Religions trans. David Reid, Richmond, Virginia: John Knox Press, 1971. 
natural law and a cosmopolitan European culture. As the earlier quoted remark of Iggers indicates, "German educated opinion now agreed that all values and rights were of historic and national origin and that alien institutions could not be transplanted to German soil." Romanticism had an almost unfathomable impact on German soclety. First, in its attempt to balance the infinite and finite in human experience and history, it Ironically set the stage for their complete separation and consequently gave a powerful impulse to secularization and the rise of the authoritarian state. Second, its overemphasis on the emotional and aesthetic aspects of life produced in philosophy and theology a preoccupation with unconscious awareness which became polarized over against reason, and thus furthered the bifurcation of the finite/infinite synthesis. Third, Romanticism, in its appreciation of individuality, produced a great awareness and appreciation for history but because it increasingly tended to emphasize the infinite it alded in the separation of form and content in history which caused a chasm to grow between historiography and theology. From the historian's point of viek, the actual meaning of history did not belong to the historian's field of interest but only to the philosopher or theologian. 55

This was the cultural and philosophical environment into which Baur was born. The political and cultural aspects of nineteenth century Germany had more of an indirect influence on him. The philosophical aspect, in contrast, had a great bearing on his life and scholarly works. It was through theology and philosophy that Baur was most deeply touched by the Romantic Revolt; a fact demonstrated by a consideration of his

55Later theologians, notably Karl Barth, reciprocated by declaring that the actual facts of history had nothing to do with theology but only with the discipline of history. 
Iife, and intellectual development. 
CHAPTER III

F. C. BAUR'S LIFE, WORKS, INTELLECTUAL DEVELOPMENT

AND THEOLOGICAL POSITION

\section{LIFE}

Ferdinand Christian Baur was born on June 21, 1792 just two months after France declared war on Austria in the village of Schmiden near Stuttgart. Although young Ferdinand grew up in the era of the French Revolution and Napoleonic wars, we have no record of how he or his family reacted to them. 1 It is possible that Ferdinand's parents, though fully aware of the French threat so close to their Rhineland home, sought to maintain a peaceful homelife in spite of it. F. C. Baur grew up in a strongly pietistic environment which succeeded in molding him into the serious and reverent Christian scholar that he was later to become. His father was Jakob Christian Baur (1755-1817) a Protestant preacher at Schmiden whom Eduard Zeller, F. C. Baur's son-in-law described as "einem sehr fleiBigen und Pflichttrenen Manne".2 Later in 1800, Baur's father became a deacon at Blaubeuren, a village about two miles from UIm, at

${ }^{1}$ The sources of information on Baur's early life are very sparse. The best sources come from his son-in-law, Eduard Zeller, who published biographical essays on Baur in Vortrage und Abhandlungen geschichtlichen Inhalts (Leipzig: Fues's Verlag, 1865), p. 357; and in Allgemeine Deutsche Biographie, vol. II (Leipzig: Duncker und Humblot, 1875), p. 172. Peter C. Hodgson has characterized these sources as "generally excellent" but warns that Zeller's comments on Baur's works are not always objective.

$$
\text { 2Zeller, All. Deut. Bio., p. } 172 .
$$


at the base of the Swabian foothills. He died in 1817, the same year in which Ferdinand received his first professorial position at Blaubeuren. Ferdinand's mother was Eberhardine Regine Gross who, "was, like her husband, an industrious, pious, hard-working, serious-minded person, marked by a touch of melancholy."3 The effect of his homelife was that:

The young Baur was shaped in the virtues his parents thought appropriate and developed as a serlous lad, having little need for companionship and possessed of a natural shyness or reserve which never left him even when he had achieved a position of importance and controversy. 4

Until Ferdinand's fourteenth year, all of his education was undertaken by his father, but in the fall of 1805, he entered the lower seminary at Blaubeuren where he spent two years.5 In 1807, he entered the Kloster Maulbronn, another lower seminary. In both of these schools there was a heavy emphasis on both Greek and Latin along with a little Hebrek. The firm grounding Baur received during these years in the classical languages paid off later, not only in his classical and philological studies, but also as tools for historical and theological research. Finally, in 1809, Baur entered the evangelical theological seminary of the University of Tübingen where he was to remain a student of philosophical and theological studies for five years. When Baur arrived at Tübingen, the intellectual environment was almost in a reactionary state against any speculative theology. The conservative pace had been set earlier by the reputed leader of the old Tübingen school, Gottlob

3 Peter C. Hodgson, Form of Hist. Theo., p. 8.

${ }^{4}$ Peter C. Hodgson, Form of Hist. Theo., p. 8.

5 An article by Karl Baur entitled "Zur Jegendgeschichte von Ferdinand Christian Baur (1805-1807)", (Theologishe Studien und Kritiken, XCV: $3 / 4(1923 / 24)$, pp. 303-313), deals more deeply with Baur's experiences at the lower seminary at Blaubeuren. 
Christian Storr, who had died just four years prior to Baur's coming, but whose influence was still largely dominant in the Tübingen theological faculty. According to Hodgson, the faculty had "adopted an unproductive and negative attitude toward the theological problems stirred up by the Impact of rationalism, and later dismissed Schlefermacher's Glaubenslehre as pantheistic when it appeared in 1821."6 Thus, Baur, although he was, as Tetz describes him, the "begabtester und fähigster Student seines Jahrgangs", found very little to stimulate him at Tübingen. One exception, however, was Ernst Gottlieb Bengel, professor of historical theology, whom Zeiler describes as "einer der freisinnigsten, von der kantischen Philosophie und der rationalistischen kritik am stärksten berührten von den Supranaturalisten aus Storr's Schule."7 It was Bengel's openminded willingness to give consideration to speculative theological thought in his treatment of historical theology that first stimulated Baur's interest in philosophical theology, and although Bengel's lectures were not steeped in erudition, nevertheless, their suggestiveness, sensibility and tastefulness worked in Baur's mind to create a keen interest in historical theology and its problems.

It was probably during his student years at Tübingen that Baur first came into contact with the ldeas of Friedrick von Schelling. The first hint that this was the case comes from a letter from Ferdinand's

${ }^{6}$ Peter C. Hodgson, Form. of Hist. Theo. p. 9. The conservative reaction of the Tübingen theological faculty was actually opposed to the same rationalistic forces as Schleiermacher but their respective reactions were obverse. Whereas the Tübingen reaction was toward a supernaturalistic confessionalism. Schleiermacher's was towards a freer speculative approach to Christian theology.

$$
\text { 7Zellex, A.11. Deut. B10., p. } 172 \text {. }
$$


brother Frledrick August Baur written to Eduard Zeller wh1ch suggests that Baur studied both Fichte and especially Schelling while still a student at Tübingen. Although Baur himself has left no indication that he studied Schelling at so early a time, there is external evidence to at least make this plausible. This evidence is primarily based on the fact that a new professor joined the Tübingen theological faculty in 1811, A. K. A. Eschenmayer, whom Zeller describes as a "freund der schellingischen Naturphilosophie". It is Zeller"s contention that Baur would naturally have had at least some exposure to Schelling's philosophy through him.8 But as both Zeller and Hodgson are aware of, when Eschenmayer began lecturing in the summer of 1812. Baur had already completed the requisite tro-year philosophical course and would not, therefore, have heard him in the course of his normal studies.9 There is therefore no hard evidence, to suppose that Baur was already moving out of his supernaturalistic theological stance through the influence of Fichte and Schelling while at Tübingen. Later, of course, Schelling had a great impact on Baur's thought as is clearly evident in his writings. Baur left Tübingen in 1814 to become a "Vikar auf dem Lande", serving the two parishes of Rolwaag and Mühlhausen, and later "Hilfslehre" at the lower theological seminaxy at Schönthal. In 1816, he returned to

\section{Eller, All. Deut. Bio., p. 173.}

9 Peter C. Hodgson The Formation of Historical Theology, pp. 9-10. Hodgs on suggests that Baur may have been exposed to Schelling's ideas through his good friend Ludwig Friedrich Heyd who entered the evangelical theological seminary at Tübingen one year after Baur (1810) and was definitely under Eschenmayer's teaching. That Heyd was impressed by Scheliing is born out by the fact that Heyd made two visits to Scheling in 1816, and it is probably true that Heyd had discussed Schelling with Baur. Thus, if Baur had not actually studied Schelling himself, he at least had a familiarity with his ideas. 
Tubingen to serve as Repetent at the seminary, and in 1817 recelved and accepted his first professorial call to the lower theological seminary at Blaubeuren, a position he retained unt1l 1826. The years at Blaubeuren were some of the most productive and fruitful for Baur and it was during this time that he became fully mature as a scholar in his own right. Hodgson writes:

This was a period for intensive reading and study, liberated from the rather narrow perspective of the old Tübingen theology. A collection of reading notes from this period shows that Baur became familiar with many contemporary works in ancient history, classical philosophy, mythology, Iinguistics, and history of religions, by such authors as Hellmann. Schlelermacher, Schlegel, Osiander, Creuzer. Hug, and Wolf.10

Baur lectured on a variety of subjects but all of them were related to the ancient world. He taught classical languages, Greek and Roman prose, including classical historians such as Livy, Tacitus, Herodotus, and Thucydides 11 , and also anclent history, mythology and Platonic philosophy. During this time, Baur was particularly impressed by B. G. Niebuhr's wark Römische Geschichte. Baur threw himself into his teaching and research with tremendous energy and resolve and was a model scholar. Zeller characterizes him at Blaubeuren as,

10 Hodgson Form. of Hist. Theo., p. 13. It is impartant to note here that even though Bawr was moving away from his supernaturalistic standpoint he never violently attacked the position as Strauss did in his Iife of Jesus. Baur's historical-critical approach was always positive in character. And, further, Baur retained a legacy from his association with the old Tübingen school, 1.e., "a I1fe-long interest in an objective theological truth." (Karl Barth, Protestant Theology in the Nineteenth Century, p. 501).

11Baur actually began and finished a scholarly translation of Thucydides' History of the Peloponnesian War during this time for publication, but it was turned down by the publisher as too 11 teral. 
Ein Mann, der allen als Vorbild eineswissenschaftlichen Charakters, eines idealen, fïr alles Edle und Große emfänglichen sinnes, einer selteren Gewissenhaftigkeit und Arbeitsluft voranleuchtete, und der immer an sich selbst noch höhere Anforderungen stellte, als an andere.12

It was while at Blaubeuren that Baur undertook a systematic study of Schelling, especially his work entitled System des Transzendentalen Idealismus (1800). The combination of Baur's early training in classical languages and Biblical studies, his association with Bengel's openminded attitude for speculative theology along with his historical studies and exposure to the idealism of Schelling all came together in Baur's mind to cause him to question the old-Tübingen supernatural approach to Biblical studies and theology. Yet characteristically, Baur was not quick to act on his feelings until he had fully worked through the attendent problems of the idealistic approach. This was born out in 1818 , when Baur wrote a critical review for the Archive fïr die Theologie on G. P. C. Kaiser's Die biblische Theologie, oder Judaismus und Christianismus nach der grammatisch-historischen Interpretations-Methode. Hodgson summarizes the article thus:

He argued that the connection between Judaism and Christianity must be treated in an histarically comprehensive way, that revealed religion must be treated under catagories drawn from studies in philosophy of religion and history of religions; and he gave evidence of having already done considerable study in history of religions and undertaken philosophical analyses of the essence and jor forms of religion. But he still held out for a supernaturally inspired, supra-histarically mediated revelation of unique religious truth, and thus drew back from treating Christianity in a fully "historical-critical" mode.13

It is clear from Baur's review of 1818 that he was moving towards his complete historical-critical position, yet he was still reluctant to

12Zeller, All. Deut. Bio., p. 173.

13Hodgson Form. of Hist. Theo., p. 10. 
embrace a speculative methodology in theological and religious studies. It wasn't until the end of his career that Baur would finally come out in favor of a speculative methodology in theology.

Another major Influence on Baur during this time was Schlelermacher's Glaubenslehre which appeared in 1821/22 and which Baur described as having a liberating influence on him. Although Baur was enthusiastic about Schleiermacher's work, he did not unreservedly endorse his results nor embrace his methodology. At this time Baur was still groping for his own position regarding methodology and could not see how Schleiermacher could retain the importance of the historical appearance of Jesus with his conception of religion as the subjective feeling of absolute depend-. ence. As will be shown later, it was on this very question that Baur disagreed most with Schleiermacher, yet the Glaubenslehre exerted a tremendous impact on Baur which was to be unexcelled by any other including Hegel. Zeller notes, that if Baur was to be considered as the disciple of any theologian it would have to be Schleiermacher for Schleiermacher's thought presented itself to Baur when he was still in his formative state. Comparing the influence of Hegel and Schlelermacher on Baur, Zeller writes:

Hegel's influence did not have as great or as lengthy an effect as that of Schleiermacher's system. Schlelermacher's thought encountered him before he had reached the crucial point of his own striving. Hegel's furnished the mature man, who had already sought his own way autonomously, something more in the way of that which he already possessed substantively. ${ }^{14}$

It was the Glaubenslehre which finally liberated Baur from his supernaturalism. Baur's first major work, Symbolik und Mythologie oder die

14 Quoted in Hodgson p. 14. See Zeller, Vorträge und Abhandlungen pp. $361,164-365$. 
Naturreligion des Altertums (1824-25), marks his formal break with the theological method of the old-Tübingen school and demonstrated the depth of Schleiermacher's influence upon him. Indeed, M. Tetz has characterized the work as "Im Religlonsverständnis und in der Anlage des Werkes ein abhängiges Gegenstück zu Schleiermachers Glaubenslehre."15 It was the Symbolik und Mythologie which earned for Baur a position in the theological faculty at Tübingen where he was called in 1826 upon the death of his former teacher and friend Bengel.

Baur's appointment at Tübingen was to teach all the historical disciplines other than the '0ld Testament; a task for which he was well prepared. Still, the broadness of his teaching area demanded of him much energy and stamina. He was assigned to teach all Church history and historical theology, New Testament theology and New Testament introduction, exegesis, symbolics, ethics and Protestant Church law. In addition to his teaching responsibilities at Tübingen, Baur was assigned the job of "fruhprediger" for the university Church, to serve on Sundays and festival days. He was one of three such preachers at the university who were ranked according to seniority, and in 1842, Baur became "erste fruhprediger". Hodgson, who has studied Baur's sermons from this time, has characterized them as:

Christocentric in focus: almost always they started with an exposition of the meaning of Jesus' teaching ministry or reconciling work as described in the Gospel text designated by the Wirttemberg lectionary; and then they moved to a personal or contemporary application of this meaning or perhaps a description of the Christian life as it is shaped by $1 t .16$

15M. Tetz, "F. C. Baur," in Neue Deutsche Biographie vol. I, (Berlin: Duncker und Humblot, 1953), p. 936.

16 Hodgson, The Formation..., pp. 19-20. 
Although some objected to a "speculative theologian" functioning in the capacity of a pulpit minister, Baur vigorously defended the combination claiming to be as much a preacher as a theologian. In practice, he kept the two capacities apart, rarely bringing his scholarly researches to bear on his preaching. Over all, Baur was happy at Tübingen, although he once expressed his dissatisfaction with the general lack of interest In matters of historical criticism, and remained there until his death 1n 1860. It was here also, that Baur embraced the general task which would occupy him the rest of his life. It was, according to Hirsch:

Die weltgeschichtliche Erscheinung des Christentums als einer von allen andern unterschiedenen sittlich-religiösen Gestaltung des menschlichen Lebens nach ihrem eigentümlichen Geiste so zu begreifen, da $\beta$ alle wesentlichen Bewegungen und Formen christlichen Denkens und Lebens durch die Jahrhunderte hindurch nach ihrem Ursprung und Verhältnis zum christlichen Prinzip sichtbar und damit als Glieder eines großen Zusammenhangs geschichtlich erfaßt und auf das Gesamtbewußtsein der geschichtlichen Menschheit bezogen würden.1?

Baur's biography, from his coming to Tübingen till his death, can best be understood through an account of his written works; therefore the discussion will now turn to these.

But before moving on, it is important to emphasize that in all Baur's works the task mentioned by Hirsch above is involved to some degree. Baur believed that there was teleological meaning in the whole process of history and further that this meaning could be discovered at least partly through an examination of the historical facts. The life of Jesus was especially important in this regard, for in 1t, Baur believed, the meaning of history is explicitly discovered. History and historical research are, therefore, extremely important for Baur's thought, but

$$
\begin{aligned}
& \text { 17Hirsch, Geschichte der nevern Evangelischen Theologie vol. IV, } \\
& \text { p. } 520 .
\end{aligned}
$$


not just history alone. Baur recognized also that history would be teleologically incomprehensible to man had it not been for Jesus. Thus, he starts with the revelation of God in Christ and reads all of history through this event. Baur's understanding of history as informed by his Christology will be dealt with later in this chapter.

\section{WORKS}

Although Baur's works are numerous and cover diverse fields, they can all be related to his general task of discerning God's purpose through the historical process. It is only when Baur's works are read in the Iight of this task that the essential positive nature of them is properly understood. His task was not to destroy but to build up. Baur saw clearly that the questions raised by Rationalism would have to be addressed and answered if the Christian faith was to remain meaningful in his day. For him, the supernatural position of the old-Tübingen school was impotent to answer the question of Rationalism or even to dialogue with it in its confessionalist reaction. Although he understood his debt to his essentially pletistic upbringing and education, he could only look with sadness upon his colleagues who became increasingly defensive and personally vindictive in their reaction to speculative theologians such as Schlelermacher and Hegel. Thus, it was in an attitude of sincerity, almost of piety, that Baur abandoned his supernatural presuppositions, in arder to explore new conceptions of Christianity.

But, while Baur abandoned his supernaturalism, he did not wholeheartedly embrace the speculative theology produced by Romanticism. He constantly demonstrated his commitment to the truth of the matter alone, 
in contrast to a commitment to a particular school, by always maintaining his scholarly distance. He knew he could learn from such men as Schelling, Schleiermacher, and Hegel, but he never read them uncritically and always expressed his commitment to the facts first. Nowhere is this more clearly spelled out than in an article entitled "Abgenöthigte Erklärung gegen einen Artikel der evangelischen Kirchenzeltung herausgegeben von D. E. W. Hengstenberg. . ".18 In this article, Baur defended himself against the charge that he was more committed to an a priori speculative position than to the facts in his New Testament exegesis, particularly his work on the pastoral epistles which appeared in 1835. Baur challenges his critics:

Nun frage ich aber: Wo stüßt sich denn meine Kritik auch nur an Einer Stelle meiner Schrift auf die mytische Ansicht? Wo verwerfe ich auch nur Ein historisches Factum, das für das kritische Urtheil über diese Briefe von Wichtigkeit ist, einzig nur aus dem Grunde, well es ein Wunder ist, oder wo argumentiere ich einzig und allein aus dem innern Widersprich des Inhalts? Überall gehe ich von bestimmten geschichtlich erhobenen Thatsachen aus, und suche auf dieser Grundlage erst die verschledenen Fäden meiner kritischen Combinationen zu Einem Ganzen zusammenzuziehen. Dieses Festhalten am geschichtlich Gegebenen ist das Eigenthümliche meiner Kritik. 19

Baur has often been dispatched in works on nineteenth century theology with a few lines to the effect that he applied Hegelian concepts to New Testament studies and is now insignificant for theology today. This

18quoted in F. C. Baur, Ausgewahlte Werke in Einzelausgaben band I, herausgegeben von Klaus Scholder (Stuttgart-Bed Canstatt: Friedrich Frommann Verlag, 1963), pp. 267-268. Hengstenberg was a leading figure in the confessionalist revival of the Luthern Church in Prussia and one of its most vociferous spokesman. As an 0ld Testament scholar, he vigorously defended the orthodox view of the inspiration of the scriptures while, just as vigarously, opposing liberal tendencies in theology. (see Josef L. Altholz, Churches in the Nineteenth Century, pp. 106-107.)

19F.C. Baur, Ausgewählte Werke... . band I, p. 294. 
Is too facile a judgment to be passed on such an objective and committed scholar as Baur. In surveying his scholarly production, while it must be granted that he intensely studied and utilized the insights of the romantic theologians, Baur must be allowed the integrity he deserves and be studied in his own right as a mature scholar committed to truth. Only then can his thought and significance be rightly apprehended.

Baur's writings can be considered in three major stages, each with its own particular subject matter. 20 The first stage of Baur's Iiterary output begins with his publication of Symbolik und Mythologie..., and ends with the publication of Die Christliche Gnosis, oder die Christliche Religions-Philosophie in Ihrer Geschichtlichen Entwicklung. (Tübingen: C. F. Osiander, 1835), when, for the first time, Baur began to make explicit use of Hegelian catagories in his work. This might be called the period of Dogmatic Development in that much of Baur's work had to do with the development of Christian dogma within the Hellenistic/Roman cultural environment.

Following the Symbolik und Mythologie..., which has already been mentioned, Baur's next important work was his inaugural dissertation at Tübingen entitled "Primae Rationalismi et Supranaturalismi Historiae Capita Potiora" which he delivered in three parts respectively on January 1827. Easter 1827, and Pentecost 1828. This work, which Hodgson

$20 \mathrm{It}$ is not my purpose here to give a complete and comprehensive catalogue of Baur's works nor to analyze them in depth. I only hope to provide a general picture of Baur's development as a scholar and the flow of his thought. Therefore, except for Baur's works on Church History, which will be examined in mare detail later. I will limit myself to brief comments on selected works in each period. For a more complete consideration of Baur's works see Zeller's article on Ferdinand Christian Baur in Allgemeine Deutsche Blographie, or G. Fraedrich's Ferdinand Christian Baur. . .' which has an almost complete account of Baur's Iiterary production. 
considers one of Baur's most important ${ }^{21}$, dealt first of all with Gnosticism, then presented Schleiermacher's thought as essentially a new form of Gnosticism. Here, Baur outlined his major dissatisfaction with Schleiermacher's system, specifically that Schleiermacher had failed to relate the ideal Christ-event with the historical Jesus.

In the period between 1826 and 1835, Baur produced many significant monographs and journal articles. In 1831 appeared a work entitled Das Manichäische Religions-System nach dem Quellen Neu Untersucht und Entwickelt, in which Baur attempted to provide an explication of Manichaean religious thought through an inductive historical study of surviving documents. This work was so well done that, as Hirsch testifies, it "noch heute, obwohl wir über weit reichere Quellen verfügen, manchen Kennern als das beste über den Manichäismus Vorhandne gilt."22 In the same year appeared perhaps Baur's most famous work, Die Christuspartei in der korinthischen Gemeinde, der Gegensatz des petrinischen und paulinischen Christenthums in der ältesten Kirche, der Apostle Petrus in Rom, which Haussleiter credits with opening up "the vista of more far-reaching historico-critical investigation into the controversies of the Apostolic Age."23 Baur challenged the 1800 year old assumption that the Corinthian congregation was monolithic in its beliefs. Rather, from I Cor. 1:12, he claimed to discern several parties within the Church which represented several different theological leanings. Although Baur isolated four such parties, under the titular heads of Peter, Paul, Apollos, and Christ,

$$
\begin{aligned}
& 21_{\text {Hodgson, Form. of Hist. Theo., p. } 17 .} \\
& 22 \text { Hirsch, Geschichte..., Vol. V., p. } 520 . \\
& \text { 23J. Haussleiter, "Ferdinand Christian Baur", The New Schaff-Herzog } \\
& \text { Religious Encyclopedia, II (New York: Funk and Wagnalls Co., 1958), p. } 8 .
\end{aligned}
$$


he discerned two basic poles, the Judaic (Peterine) and Hellenistic (Pauline), which came into conflict. Baur proposed that the Church of the second century was born out of the struggle between the Judaic and Hellenistic elements which found their synthesis in the fourth gospel. Baur held on to this conception of the rise of the early Church for the rest of his life, something which had effects on all of his further Biblical studies as Käsemann indicates:

War die frühkatholische Kirche aus einer Antithese und, radikal gesehen, aus den belden verschiedenen Ursprüngen des Judenchristentums und des Paulinismus erwachsen, so solgte Daraus unvermeid bar ein dogmengeschichtliches Programm, welches die Grenzen des Neuen Testamentes weit übergreifen mußte. Zugleich war für die neutestamentIlchen Schriften ein hermene istischer Schlüssel gefunden, welcher erlaubte, sie in höchst differenzierter Weise und unterscheidlicher Annäherung auf die beiden Pole hin auszurichten. 24

Before proceeding with this survey of Baur's works, it might be helpful to make here some comments about his association with Hegel's philosophy. Because Baur was definitely influenced by Hegel in his later works, and because the Die Christusparte1... contains a Hegelianlike dialectic in its main thesis, the tendency of scholars has been to consider it as the first instance of explicit Hegelian influence on Baur. But, as Hodgson has clearly shown in his book The Farmation of Histarical Theology, Bair probably did not extensively study Hegel until 1834-35, after he had produced his work on the Corinthian party and established his views on the dialectical production of the early Church. Hodgson provides evidence from Baur's letters that the Hegelian influence came

24Ernst Käsemann in the introduction to F. C. Baur, Ausgewählte Werke Band I., p. XI. 
while he was engaged in another work which was published in 1835 under the title: Die Christliche Gnosis, oder die Christliche ReligionsPhilosophie in ihrer Geschichtlichen Entwicklung. He writes:

In a letter written in February 1835 Baw indicated that, in connection with his work on Die Christliche Gnosis, which by then had continued "for more than a year", Hegel's Religionsphilosophie has especially occupied me this winter (1834-35). and in many respects attracts me. Thus, I am likely to come up against the fact that $I$ am not able to find in it the atrocities customarily attributed to it.25

Hodgson goes on to cite another letter in which Baur explicitly states that it was in connection with Die Christliche Gnosis that he first fully considered Hegel's philosophy and was influenced by it.26 Thus, Baur's New Testament studies, although influenced by Hegel, are not simply direct application of Hegel's ideas to scripture. In fact, the whole Idea of Hegelian influence on Baur, while granted, must be qualified for several reasons. In the first place, as was indicated above in his response to Hengstenburg's criticisms, Baur upheld his objectivity against the charge of letting personal bias color the results of his work. He was particularly insistent about this point. Still, he was willing to Iisten to and embrace another's position if it showed the possibility of bearing scholarly fruit. This was his attitude toward Hegel's philosophy. He wrote:

Ich bin kein Anhänger irgend elnes philosophischen Systems, weil ich wohl wei $B$, wie trüglich es ist sich von Menschenauktorität abhäglg zu machen, aber gleichwohl habe ich die Ueberzemgung, daß sich auch von Hegel gar manches fur die Theologielernen läbt, und glaube, daß auch Manche von denen, welche so schnell Beriet sind, über ihn abzusprechen, anders urthellen wïrden, wenn sie sich entschliesen könnten, seine Schriften

$$
\begin{aligned}
& 25 \text { Hodgs on, Form. of Hist. Theo., p. } 23 . \\
& 26 \text { Hodgs on, Form. of Hist. Theo., p. 23-24. }
\end{aligned}
$$


zuvor näher kennen zu lernen.27

In the second place, Baur evidences in his work a greater appreciation for the particulars of history than does Hegel. In Hodgson's words, he wishes to "elicit meaning and rationality from history rather than to impose it on history."28 Although Hegel attempted to synthesize the absolute and particulars of history, his tendency was to increasingly emphasize the absolute meaning of history and to show distain for the facts. This was a general problem with many of the Romantic syntheses. Baur, on the other hand, insisted that both be considered, but also, that both be balanced. Hodgson finds this insistence most fully developed in his works on Church history, writing:

He insisted that historical study of the Church is at once a speculative (philosophical-theological) and an empirical (objective, critical) procedure, that these are two components in the same process of understanding, that methodological priority can be given to neither, and that neither may be sacrificed to the other.29

The main point of this orbita dicta is, above all, to say that "Hegelian" is too scant a label to cover the uniqueness of Baur. While he benefited from Hegel, he did not merely assume his ideological Weltanschauung and apply it to his own work.

In other works from this period, Baur showed himself intent on pursuing the methodology established in Die Christus Partei.... For example, in Apollonius von Tyana und Christus, oder das Verhältniss des Pythagaräismus zum Christenthum (1832) Bavr again sought to show the 27F. C. Baur, Ausgewählte Werke...Band I., p. 313, in the footnote. 28 Hodgs on, Form. of Hist. Theo., p. 4.

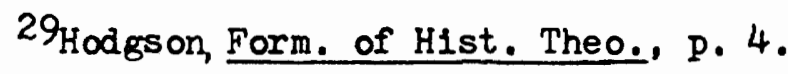


impact of the Hellenistic environment on Christianity. Particularly, in this work, according to Zeller, "zelgte er hler in der Blographie des Philostratus einen neupythagoreischen Tendenzroman auf, und wenn er vorher die Ebioniten von den Essenern hergele1tet hatte, verfolgte er jeBt den Ursprung der leBteren weiter hinauf zu den Neupythagoreern. "30 Baur applied his historical method to Judaism in Pber die Ursprungliche Bedeutung des Passahfestes und des Beschneidungsritus which also appeared in 1832 .

In the following year, Baur felt compelled to take time away from his historical studies to respond to a book by Johann Adam Möhler entitled Symbolik oder Darstellung der Dogmat1schen Gegensätze der Katholiken unż Protestanten (1832) which attacked Protestant speculative theology as hopelessly speculative and out of line with the Protestant tradition. According to Zeller.

Die Angrisse, welche dieser gelehrte und geistvolle Restauratar des modernen Katholicismus in seiner "Symbolik" auf die protestantische Kirche, ihre Lehre und ihrer Stifter gemacht, die Geschichtsentstellungen, die er sich erlaubt hatte, forderten den protestantischen Symboliker zur Abwehr heraus. 31

In h1s response to Möhler entitled Der Gegensatz des Katholic1smus und Protestantismus.... he examined the differences between the two theological systems based on the major dogmatic expressions of both. He argued that Protestant idealism did represent a direct continuation of the Protestant spirit but that it also had marked similarities with ancient Christian Gnosticism. On the other hand, he considered Catholicism to be a continuation of the early Jewish character of the Church

$$
\begin{aligned}
& \text { 30zeller, All. Deut. B10., p. } 175 . \\
& 31 \text { Zeller, All. Deut. B10., p. } 175 .
\end{aligned}
$$


with its emphasis on law and structure. Baur recognized defects in both systems and suggested that some sort of synthesis was necessary between both these positions. It was at this point that the name of Hegel first appeared in Baur's mitings.

The second major period of Baur's literary career, which might be called the Biblical critical period, falls roughly between 1835 and 1847 , from the time when he began to utilize Hegelian categaries in his work, until the publication of Ober Prinzip und Charakter des Lehrbegriffs der Reformierten Kirche, in seinem Unterschied von der Lutherischen, in which Baur first evidenced more interest in the moral cultic aspects of religion as opposed to the theological or dogmatic, and also began to emphasize a subjective human freedom over against divine determinism worked out through inexorable laws of historical development.

It was during this period that the so-called Tübingen school grew up around Baur at the university. Its allies were not those holding theological chatrs in Germany, but rather, young, enthusiastic and, sometimes rash disciples such as Eduard Zeller, who later became Baur's sonin-law, Schwegler, Köstlin and Planck, Ritschl, and Higenfeld. Their program was, in essence, to understand Christianity in its complete historicity, rather than, as the old Tübingen school held, a supernatural and suprahistorical enclave in the world, and they did not hesitate to apply their religionsgeschichtliche methods to the scriptures as well. As Baur himself wrote:

Das Christentum ist und bleibt eine geschichtliche gegebene Religion. . .Es ist zu einer bestimmten Zeit in den allgemeinen Zuzammenhang der geschichtlichen Erelgnisse eingetreten und kann nur aus bestimmten schriften, als den urkundlichen Zeugen seines 
Ursprungs erkannt werden. . .32

Contrary to what this statement may imply, the historical method of the Tübingen school was essentially positive since its adherents believed that in the historical events, or more specifically in the dialectical confrontation of antithetical ideas and doctrines, could be seen the spirit of God making itself known through reconciliation. Therefore, they had nothing to fear from critical historiographic methods. On the contrary, the more radically this method was applied, the better, since it could only reveal more clearly the message of God's reconciliation. But to those who did not understand this underlying assumption or who did understand it but disagreed with it, the historico-critical method of Biblical studies appeared as the most pernicious of evils. This was one of the most disheartening and stormy periods of Baur's life, a fact which is indicated in a letter to his son F. A. Baur dated $29 \mathrm{July} 1836$, when he wrote: "From day to day it becomes less healthy in science and in life, and one has to proceed so as not to lose courage entirely." 33

During this period, Baur produced many monographs dealing with the gospels and epistles, applying the same methodology he had earlier applied in his work on the Corinthian congregation. In 1835, appeared Die Sogenannten Pastoralbriefe des Apostles Paulus aufs Meue Kritisch Untersucht in which Baur rejected Pauline autharship of the epistles because, he held, the heretics addressed therein were Gnostics, a post-Pauline movement of around the mid-second century A. D.. 1836 saw the publication

32 Quoted by Klaus Scholder in the forward of F. C. Baur's Ausgewählte Werke Vol. I, p. vi.

33quoted in Hodgson, Form. of Hist. Theo., p. 17 in footnote \#70. 
of Uber Zweck und Veranlassung des Romerbriefs, an examination of the Epistle to the Romans to determine its addressees. Thus, Hodgs on characterized it:

Just as the key to Corinthians (and thus to the whole history of prinitive Christianity) was provided by the description of opposition between those who claimed to belong to Paul, to Appollos, to Cephas, and "to Christ" in I Cor. 1:12, so likewise the clue to Romans is chapters 9-11, where Paul addresses himself to his "kinsmen by race" and raises the fundamental question of the relation of Judaism to the Gospel.34

In 1845, these and other monographs on the Pauline epistles were drawn together into a book on Paul himself entitled Paulus, der Apostle Jesu Christi, which Hodgson claims is the "most important contribution to Pauline studies of the nineteenth century."35 In this culminating work, according to haussleiter, was "the denial of the authenticity of all the letters passing under the apostle's name, except Galations, I and II Corinthians, and Romans, the last two chapters of which were of questionable authenticity. " 36

34 P. C. Hodgson, "Rediscovery of F. C. Baur" in Church History Vol. xxx111 June, 1964, p. 207.

35P. C. Hodgson, Form. of Hist. Theo., p. 27.

36 Haussle1ter, New Schaff-Herzog, p. 9. It is interesting to note here that Baur was preparing a new edition of Paulus. . . towards the end of his life, which, unfortunately was cut short by his death in 1860. However, in the posthumously published "Vorlesungen über Neutestamentliche Theologie, A. Schweitzer noted that "The chapter on Paulinism is very striking in its brevity and clearness, and shows a great advance on the work of 1845. At that time Baur had examined and interpreted Paul's teaching by the light of the Hegelian Intellectualism. Now, he tries to grasp his ideas histarically and empirically, and to describe them accordingly." (A. Schweitzer, Paul and His Interpreters trans. W. Montgomery, (Lond on: Adam and Charles Black, 1912), pp. 20-21) Not only does this indicate Baur's constant criticism of his own work, but also his general drift towards a more radical application of the historical method to New Testament history. 
Baur also applied his historico-critical method to the gospels and thus, indirectly to the Iife of Jesus, but his major concern is the documents of the New Testament gospels. Here, a basic differentiation from Strauss' method is seen in Baur. Although, he was accused of taking the suggestions of Strauss and working them out, 37 still, as Schweitzer has correctly observed, "In the end he had only given a criticism of the gospels, not of the gospel history."38 The liturature Baur produced on the gospels is vast yet the same theme of the dialectical struggle in the early Church, between Jewish and Hellenistic parties is featured in them all. In fact, as Käsemann indicates, it was within the thesis of the dialectical struggle that "Zugleich war fïr die neutestamentlichen Schriften ein hermeneutischer Schlüssel gefunden."39 But, lest he be accused of arbitrarily applying a theory of dialectical development to the New Testament documents, it must be remembered that Baur's theories developed out of his own researches; particularly in his study of the Christ party within the Corinthian congregation. Iater, Baur utilized Hegel, not uncritically, but only where he discovered evidence for a dialectical confrontation. Some of the major titles from this period are: tber die Composition und den Charakter des johannel'schen Evangeliums, (1844)

37See in "Abgenöthigte Erklärung.... :" where Bawr quotes Hengstenberg as saying "Wir wollen aber absichtlich nur zweier Manner gedenken, welche bisher ihren Kenntnissen wie Bestrebungen nach zu den Tuchtigeren gezählt wurden, solcher, von denen grade Besseres $z u$ erwarten gewesen wäre, und welche erst nach StrauB und unter dem Einflusse desselben mit thren Ansichten hervorgetreten sind Professor WeiBe in Lelpzig und Baur in Tübingen." (In Ausgewählte Werke Vol. I, p. 269).

38 Albert Schweitzer, The Quest of the Historical Jesus, trans. W. Montgomery, (London: Adam and Charles Black, 1910), p. 195.

39E. Käsemann, introduction to Ausgewählte Werke Band I., p. xi. 
in which he first attacked the authenticity of the fourth gospel; Der Ursprung und Charakter des Lukas evangeliums (1846), in which he claimed that Luke was a Pauline-inspired gospel which had later been revised; and the Kritischen Untersuchungen uber die kangnischen Evangelien (1847), which was a comprehensive summary of his work and a reconstruction of the environment which produced the New Testament gospels and epistles. Regarding the gospels, Baur held that the order of the canon represented their order of composition even though he revised their respective dates of composition. Matthew was considered the earliest gospel because of its distinctly Juda1c flavor; Mark was considered after Matthew because the Judaic tendencies were not as strong; Luke came next because of its distinctly Pauline flavor, and John came last. Baur considered the fourth gospel to have been written in the mid-second century A. D. because it seemed to synthesize the Judaic and Pauline "tendencies" into a higher unity, and to argue against heretical Christian movements of that time period, notably Gnosticism and Montanism. Regarding the environment which produced both the gospels and epistles, Zeller provides an excellent summary:

Es habe auch schon in der apostolischen Kirche und unter den Hauptern derselben nicht die Uebereinstimmung der Ansichten gekerrscht, die man gewohnlich vorausseßt; das älteste Christenthum, das der jernsalemitischen Gemeinde und inrer Apostel, habe dem Judenthum noch sehr nahe gestanden; erst Paulus habe die christliche Religion von dieser Beschranktheit befireit, aber die große Mehrzahl der Juden christen und die Urapostel selbst haben sich mit seinem Universalismus nicht zu befreunden gewußt und seien demselben bald mit größerer bald mit geringerer Entscheidenheit, theilweise mit leidenschaftlicher Feindseligkeit entgegengetreten; in diesem Partelkampf habe die judenchristliche oder ebionitische Partel langere Ze1t das Uebergewicht behaupt, und exst lange nach dem Tode des Paulus, und im wesentlichen erst unter dem Einfluß der durch die Gnosis hervorgerufenen Bewegung, um die Mitte und nach der Mette des zweiten Jahrhunderts, haben sich dei streitenden Parteien, nach mancherlei unvollkommeneren 
Vermittlungsversuchen, durch die Dogmatik des vierten Evangeliums und die bischöfliche Verfassung zur allgemeinen oder katholischen Kirche vereinigt. 40

Although Baur's interests shifted towards historical theology and Church history in the later years of his life, he continued to produce periodical literature on the biblical documents until the end of his life. In 1848 came both "Die johanneIsschen Evangelium und die Passahfeier des . i. zweiten Jahrhenderts" and "Die johannelschen Breife;" in 1851 and 1853 appeared respectively, "Das Marcusevangelium nach seinem Ursprung und Charakter" and Ruckblick auf die neuesten Untersuchungen über das Marcusevangelium;" and in 1854 and 1857 came "Die johannelsche Frage und ihre neuesten Beantwortungen," and "Đas Verhaltnib des ersten johannelschen Briefes zum johannelschen Evangelium."

Before turning from Baur's Biblical studies to the last literary period of his life, something should be said about the ongoing importance of his work in this area. Karl Barth, who seems to be one of the few theologians willing to give Baur the credit he deserves, argues that simply because the school no longer exists, "does not tell the least against its significance," and goes to say:

Although the particular historical form of its method, together with its most important results, may have vanished, one might say that like an association which has fulfilled the purpose for which it was founded, it might finally dissolve with all honor because the substance of its concern, which in the last resart was not bound up with its method, found a home even among its opporents, because this substance of their concern has become and remained until now the common property of all modern theology. 41

Barth goes on to claim that without the questions which Baur formulated

$$
\begin{aligned}
& 40_{\mathrm{E}} \text {. Zeller, All. Deut. Bio., p. 177-78. } \\
& 41_{\mathrm{K}} \text {. Barth, 19th Cen. Theo., p. } 500 .
\end{aligned}
$$


"a Christian theology which to some extent understands and grasps its theme is quite inconceivable," and concludes that any dismissal of Baur as "obsolete" is at best premature. 42 Brnst käsemann, In his introduction to a recent edition of Baur's works on Biblical criticism, concurs with Barth on Baur's importance in general, but criticizes his conclusions especially in Die Christus Partei... He writes:

Diese Deutung Baurs, die sich fast nur auf eine fragwürdige Auslegung von $2 \mathrm{~K}, 10-13$ stüßen kann, ist unhaltbar. Nicht die Petriner, die wohl nur eine kleine und herseitsterrorlsierte Minorität in Korinth bildeten, sondern die radikalem Enthusiasmus verfallen en Anhänger de1 Apollos bildeten die wirkuchen Gegner des Paulus. 43

Käsemann is undoubtedly correct in his assessment here of Baur's results in Die Christus Partei... but, as Hodgson questions, is this really a rejection of Baur's basic contention, that the Church developed out of a dialectical struggle between opposing ldeas? Hodgson answers: "Not at all", and writes of Käsemann's evaluation:

Rather, it suggests that the oppositions were different and more complex than Baur had recognized: there was not simply a Jewish-Pauline struggle in the first century; there were Hellenistic spiritualists and Gnostics as well. . Baur's basic point would seem to be strengthened rather than diminished by the recognition of greater complexity in this internal development, and Baur would have been the first to acknowledge that his reconstruction could be rendered "too simple" by the discovery of fresh data. 44

In sum then, Baur's work on New Testament introduction and history is still valuable today, not so much in its results and conclusions, as in its foundational statement of problems of New Testament introduetioni which remain today important as they were in Baur's day. Baur certainly

$42_{\mathrm{K}}$. Barth, 19th Cent. Theo., p. 500.

$43 \mathrm{E}$. Käsemann, introduction to Ausgewählte Werke Band I, p. x. 44P. C. Hodgson, the Rediscovery of F. C. Baur," p. 208. 
did not have the last word on these questions, and he would have been the first to admit this. It is, rather, because Baur had the first word on many of these issues that he is important as Scholder states:

Ferdinand Christian Baurs Werk stellt sich uns heute als die reinste Ausprägung des noch ungebrochenen historischen Denkens in der neuren Theologlegeschichte dar. Wer immer sich mit dieser Frage beschäftigtt wird also auf ihn zurückgreifen müssen. 45

The last stage of Baur's Iiterary career was dominated by works on Church history and historical theology and might properly be called the period of Church history. The period can be considered as beginning in 1847 with the publication of Ober Prinzip und Charakter des Lehrbegriffs. when, as indicated earlier, Baur showed more of an interest in the institutional aspects of the Church (i.e.. moral and cultic) than in theological or dogmatic aspects, but there were external factors which tended to perhaps change Baur's focus slightly. The revolutionary political movements in German\$ in 1848 and their ignominius outcome had an indirect adverse effect on the school. While the school had benefited from the early revolutionary impulse and had thus loosely tied itself to it, the subsequent fallure of the Revolution of 1848 and the consequent success of the counter-revolution of the "revolution from above" put the adherents of the school in a bad light. The question arose as to whether or not the followers of the Tübingen school ought to be, or even could possibly be, involved in ecclesiastical affairs. This question, Haussleiter writes:

was answered in the negative not only be opponents; some of Baur's own disciples felt that they must either modify the scientific conclusions they had learned from him, or seek a secular calling. . . It was not surprising, then, that the German governments thought twice before appointing to academic positions men whose influence was so disturbing, and that the younger generation hesitated to follow Baur further, after his most

45K. Scholder in the Forward to F. C. Baur's Ausgewählte Werke Band. I, p. vi. 
important disciple, Zeller, was obliged in 1849 to exchange a theological chair for that of philosophy at Marburg. Bauf felt the isolation in which he thus began to find himself. . .46

Perhaps it was Baur's frustration over the generally negative reception his theological ideas had received, combined with this most recent set back which compelled him to strike out in search of a more comprehensive understanding of the relation between Christianity and culture and a more adequate model in which to understand the historical development of theology and the Church. Whatever the case, this change in emphasis was not at all a divergence from his original intent, which was to understand Christianity as the product of historical factors. In the first stage, he had examined the development of Christian dogma in the light of its Greco-Roman milieu. In the second stage, he had applied these same methods to the New Testament epistles and gospels. Now, in the final stage, Baur wished to comprehend the whole of Church histary both institutionally and theologically. But throughout these three periods, Barr's fundamental viewpoint remained unchanged, although, as Hodgson maintains, "His categories, emphases, and data were continually being modified and revised .047

Some of the works of this period will be described in greater detail in the next chapter, others will only be named here, and briefly commented on, to show the flow of Baur's thought. In 1852, appeared Die Epochen der Kirchlichen Geschichtschreitsung which was intended to serve as the introduction to his magnum opus on the history of the Church, and which Hirsch characterizes as "ein bis heute noch nicht durch ein

$$
\begin{aligned}
& \text { 46 Haussleiter, "F. C. Baur" Schaff-Herzog, p. } 10 . \\
& \text { 47Hodgson, The Form. of Hist. Theo,, p. } 22
\end{aligned}
$$


gleichartiges oder besseres ersetztes Werk."48 Following this work, came the first two volumes of his general Church history: Das Christentum und die Kirche der drei ersten Jahrhunderte (1853), and Die Christliche Kirche vom Anfang des vierten bis zum Ende des sechsten Jahrhunderts (1859). Baw had completed the third volume entitled Die Christliche Kirche des Mittelalters in den Hauptmomenten ihrer Entwicklung, but death intervened before he could see it published. It was published under the editorship of his son Ferdinand Friedrich Baur in 1861, but the form and content were F. C. Baur's own. Volumes four and five, entitled Kirchengeschichte der neueren Zeit, von der Reformation bis zum Ende des achtzehnten Jahrhunderts (1863) and Kirchengeschichte des neunzehnten Jahrhunderts (1862) were published under the respective editorships of Ferdinand Friedrich Baur and Eduard Zeller. The first volume of this work: Das Christentum und die Kirche...., is indisputably the greatest of Baur's literary' works. Dilthey has written of this work:

Sie ist Baurs reifstes Werk. . Das Buch ist der vielleicht der tiefsinnigste Versuch ein historisches Phänomen durch Zerlegung in seine wesentlichen Wirkungsformen zu erfassen. 49

In addition to his works on Church history, Baur also wrote and lectured on historical theology and the history of Dogma during the latter years of his life, and some of his ideas were published on the basis of his lecture notes, under the editorship of his son F. F. Baur. The Vorlesungen über die Christliche Dogmengeschichte was published in three volumes with volume one containing two parts. The titles were:

\footnotetext{
p. 524 .

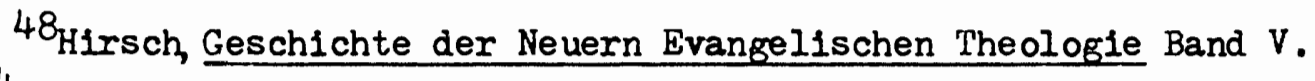

49 Wilhelm Dilthey, Gesammelte Schriften Band IV, (Stuttgart: B. G. Verlagsgesellschaft, 1959), pp. 429-430. 
Vol. I/1, Das Dogma der alten Kirche von der apostolischen Zeit bis zur Synode in Nicäa (1865); Vol. I/2, Das Dogma der alten Kirche von der Synode in Nicäa bis zum Ende des sechsten Jahrhunderts (1866); Vol. II, Das Dogma des Mittelalters (1866); Vol. III, Das Dogma der neueren Zeit (1867). Although F.F. Baur did not provide the dates of the manuscripts from which he took the material for this edition, Hodgs on has, through comparing the text w1th Baur's Lehrbuch der Christlichen Dogmengeschichte (1847,1858), argued that these works cannot be considered as among Baur's latest works. In fact, Hodgson considers the thoughts in the Vorlesungen. . . to have been written sometime between $1842 / 43$ and the first publication of the Lehrbuch. . In 1847. If this is correct, then the works on Church history are not only important because of their content, but of crucial importance to understanding Baur's most mature thought. But before turning to these works, two further things must be dispensed with in this chapter: Baur's intellectual development, and his ideas on Christology which represent the key to his philosophy of histary.

\section{INTELIECTUAL DEVELOPMENT}

Throughout the previous discussion of Baur's Iife and works, three names were mentioned as having a profound impact on Baur's development and mature thought: Schelling, Schleiermacher, and Hegel. It has been indicated, in general, when Baur came under the influence of these men, and also to what extent he was influenced by them. The purpose of this section, is to pass beyond what has already been said, and to indicate in what specific areas Baur was influenced by their ideas. Although Hegel chronologically preceeds Schleiermacher, the discussion will proceed 
according to when each Individual influenced Baur, therefore, the order of treatment will be: Schelling, Schleiermacher, and Hegel.

Before examining each of the individuals, it is important to give a general statement of the problem these romantic philosophers were addressing. As Dorner notes: Up until 1600, the primary emphasis of philosophy had been on the objective world, 1.e., nature.50 Subjectivity, or reason is considered here, but in the relation of subject/object, object predominates. This position can be illustrated from the Lutheran distinction of articuli puri et mixti.51 The articuli puri, on the one hand, are those principles which are known from the Word of God and are strictly matters of faith in Holy Writ. Included here, would bet thel historical and efficacious act of Jesus and the doctrine of the Trinity. On the other hand, are the articuli mixti; those principles which are to some degree or another, known by reason. The articuli mixti are less certain than the articuli puri because they are founded upon human reason which, in its fallen state, is fallible and obscure. Thus, the articuli mixti are only to be embraced as they can be shown to agree with Holy Scripture. It is one thing to know there is a God from rational proofs, but entirely another to belleve it because it is revealed.

At the root of this view, is the very supernaturalism which Baur rejected because it dichotomized the subject-object relationship rather $50 \mathrm{~J}$. A. Dorner, History of Protestant Theology Vol. II, trans. Rev. George Robson and Sophia Taylor (New York, AMS Press, 1970), p. 357.

51 This particular example of the old Protestant orthodoxy is discussed at length in Dorner, History of Protestant Theology, Vol. II, pp. 114-118. As a source far and explication of the reaction against the old Protestant supernaturalism, Dorner is especially good since he was a contemporary of Baur and sympathized with his views even though he didn't go as far as Baur in criticism. 
than considering them together. According to this position, "revelation" is merely the given, as Dorner explains:

\begin{abstract}
"Revelation" is found solely in the positive, the historical; nay, by degrees the secondary, i.e. the records of historical revelation, the Holy Scriptures, are taken for "revelation"; and thus Holy Scripture with its doctrines is put in place of the vital facts of revelation. "Fides", moreover, was not regarded as the Christianized form and self-certainty of the mind, i.e. of truly enlightened reason, but only as the reception into the mind of the contents of Scriptural and Church teaching. 52
\end{abstract}

Not only does faith depend upon the Holy Scriptures, its inspiration and miracles, but faith is equated merely with acceptingtheir actual historicity, "as if", mocks Dorner, "it were possible for an unbeliever to believe in Scripture, without in some way or other previously believing in God."53 Thus, objectivity is paramountly important for true knowledge while the subjective rational response is always to be judged and rejected or validated by it. The rise of the Tübingen school can generally be seen as a consequence of a new subjective emphasis in theology, as opposed to the old objective-supernaturalism, but not, at least for Baur, an overly-subjective approach. For him, object and subject, while theoretically distinguishable, are inseparable.

The reaction to this objective emphasis toward subjectivity really gets underway in the eighteenth century when the subjective response of reason assumes the role played by Holy Scripture. This development has already been discussed in chapter two regarding the question of faith and history. But the result is, in Kant, a new dichotomy between the noumenal and phenomenal with emphasis on the subjective, or rational. A

52Dorner, History of Protestant Theology, p. 115.

53 Dorner, History of Protestant Theology, p. 116. 
student of Kant, Johann Gottlieb Fichte (1762-1814), was also interested in finding a synthetic view of the Eubject-Object relationship, but his work, like Kant's was judged to be lacking by the romantic philosophers and theologians, because of its overly subjective character, which, while pretending to embody both subject and object, actually polarized them. Hegel criticizes Fichte's solution thus:

The basic character of Fichte's principle, is that the SubjectObject steps out of its identity and is unable to reestablish itself in it because the different (i.e., pure and empirical consciousness) gets transposed into the causal relation. The principle of identity does not become principle of the system; as soon as the fomation of the system begins, identity is abandoned. The system itself is a consistent product of the intellect a mass of finitudes, which the original identity cannot draw together into the focus of totality or to its absolute selfintuition. The Subject-Object, therefore, turns itself into a subjective Subject-object and it does not succeed in suspending this subjectivity and positing itself objectively. 54

Fichte's problem is his system, which, in analyzing both Subject-Object, is unable to hold them together. Hegel's basic critique of Fichte, is that his system is too subjective and therefore, too contingent to effectively hold Subject-Object together. This is what he means by a subjective Subject-Object. The essay from which the above quote was taken, was Hegel's first acknowledged publication, and appeared long before he attained his position of overwhelming importance, yet already Hegel provides hints of his later influential ideas. His solution of the SubjectObject dichotomy will be found in Reason, whose "sole interest" is to "suspend such rigid antitheses."55 "What Reason opposes", he writes, "is just the absolute fixity which the intellect gives to the dichotomy".

54 G. W. F. Hegel, The Difference Between Fichte's and Schelling's System of Philosophy, trans. H. S. Harris and Walter Cerf (Albany, N.Y.: State University of New York Press, 1977), p. 155.

55 G. W. F. Hegel, The Difference Between. ... p. 90. 
And thus:

with respect to the given dichotomy the need is the necessary attempt to suspend the rigidified opposition between subjectivity and objectivity; to comprehend the achieved existence (das Gewordensein) of the intellectual and real world as a becoming. Its being as a product must be comprehended as a producing. In the infinite activity of becoming and producing, Reason has united what was sundered and it has reduced the absolute dichotomy to a relative one, one that is conditioned by the original identity. When, where and in what forms such self-reproductions of Reason occur as philosophies is contingent. This contingency must be comprehended on the basis of the Absolute positing itself as an objective totality .56

This last statement of Hegel's is indicative of the general task before the romantic philosophers and theologians, i.e., to develop a philosophical system in which both objectivity and subjectivity will become unified in an ultimate principle. This ultimate principle, is to be identified with Hegel's Absolute, "which can, if there is to be any knowledge at all, be neither mere substance, the inflexible objective existence of Spinoza; nor, on the other hand, mere primary subject, the selfcontained primary monad on which Deism insists." 57 Baur felt the tension of the Subject/Object dichotomy and consequently felt the same need for resolution and harmony as did Schelling, Hegel, and Schleiermacher. It was this mutual concern which attracted him to the works of these men. Of these, Schelling was the first important influence.

\section{$\underline{\text { Schelling }}$}

F. W. J. Schelling $(1775-1854)$ was fully a child of the era of the French Revolution and the Romantic Revolt in Germany. In 1790, at the age of 15 , he came to Tübingen when the revolutionary events were still $56_{G}$. W. F. Hegel, The Difference Between. .., p. 91. 57Dorner, History of Protestant Theology, p. 358. 
looked on by the European intellectual community favorably. There, as noted earlier, he joined Hegel in planting a tree of liberty in honor of the French Revolution. But later, when the Revolution took on more nationalistic overtones, Schelling showed himself to be loyal to his German homeland. The Revolution was, in Dilthey's words: "Der große Vorgang, der die Tübinger Freunde ergriff," and the catalyst which bonded the students together in a political club. 58

Schelling reacted against the subjectivism of the Enlightenment, personified in Kant, to seek a synthesis of Subject and object. But Schelling represents more than just this synthesis and more than a bridge between Kant and Hegel as he is often treated. He is the "philosopher of Romanticism" who stayed with the flow of Romanticism throughout its history until it entered its existentialist phase.59 Paul Tillich, who wrote his Ph.D. thesis on Schelling and wrote a great deal on Schelling subsequently, sums his philosophy up as "an attempt to show the indwelling of the potential spirit in all natural objects and how it comes to its fulfillment in man," which is none other than the Romantic philosophy of nature. 60 His philosophy is, to some degree, a reaction against Fichte who viewed nature as, "only the material which man must use in himself,

\section{Wilhelm Dilthey, Gesammelte Schriften, Band IV, p. 13.}

59Paul Tillich, Perspectives. .., p. 142. The recognition of Schelling's importance in his own right instead of only as the "bridge" between Kant and Hegel seems to be breaking through in philosophic studies. In one recent study of Schelling, the author states: "It was Schelling who drew up the table of contents of German Idealism, defined the problems philosophers would concern themselves with for decades, and, indeed, probably took idealism as for as it could go in the process." (Joseph I. Esposito, Schelling's Idealism and Philosophy of Nature. (Lewisburg, VA.: Bucknell University Press, 1977), p. 9.)

60 Tillich, Perspectives..., p. 145. 
in his body which is nature, and outside of himself in his surroundings, in order to actualize the moral imperative."61 Here most clearly is seen Schelling's distaste for total subjectivism. This reaction is just as much a reaction against Kantian ethics, which stressed the role of practical reason in recognizing and acting upon the moral imperative, as it is a response to Fichte's subjectivism, and for this reason, Tillich regards Schelling's ideas as a "resurgence of the idea of grace over against law." He continues:

Schelling's philosophy or theology was very much a doctrine of grace, stressing the given divine reality before our merits and before our moral acts. So natural philosophy was a way of rediscovering grace over against the moralism of the Enlightenment. This was one of the great achievements of Romanticism for theology. 62

The portrayal of romantic philosophy as the rediscovery of grace could be exampled to an even greater degree by the philosophy of Schlelermacher, who will be considered shortly.

Baur was especially influenced by Schelling's conception of history as revelation and further by his outline of an historical method which would comprehend historical reality in both its universal and particular aspects. The System des Transzendentalen Idealismus, was the most influential work on Baur. Here, Schelling gropes for the synthetic union of Subject and Object in all knowledge and states his guiding task as:

Im Wissen selbst--indem ich we1B--ist Objektives und Subjektives so vereinigt, daß man nicht sagen kann, welchem von beiden die Priorität zukomme. Es ist hier kein Erstes und kein Zweites, beide sind gleichzeltig und Eins. Indem.1ch diese Identitit erklären, muß $1 \mathrm{ch}$, da mir außer jenen beiden Faktoren des Wissens (als / Erklärungs-Prinzip) sonst nichts gegeben ist, notwendig

$$
\begin{aligned}
& \text { 61 T1llich, Perspectives..., p. } 146 . \\
& \text { 62 T1llich, Perspectives..., p. } 147 .
\end{aligned}
$$


den einen dem andern vorsetzen, von dem einen ausgehen, um von inm auf den andern zu kommen; von welchem von beiden ich ausgehe, ist durch die Aufgabe nicht bestimmt. 63

Schelling continues by noting that he can either start with "das Objektive" in which case the question will be: "Wie ein Subjektives zu inm hinzukomme, das mit inm ubereinstimmt?"64, or he can begin with "das Subjektive" which involves the question: "Wie ein Objektives hinzukomme, das mit inm übereinstimmt?".65 In the course of the argument, Schelling selects a subjective approach because "das Subjektive" is "das Erste, und einziger Grund aller Realität",66 yet his approach is a truly transcendental one, for:

Wenn dem Transzendental-Philosophen nur das Subjektive ursprüngliche Realität hat, so wird er auch nur das Subjektive im Wissen sich unmittelbar zum Objekt machen: das Objektive wird ihm nur indirekt zum Objekt werden, und anstatt da $B$ im gemeinen Wissen das Wissen selbst (der Akt des Wissens) über dem Objekt verschwindet, wird im Transzendentalen umgekehrt über dem Akt des Wissens das Objekt als solches verschwinden. 67

Therefore, Schelling characterizes transcendental knowledge as "ein Wissen des Wissens, insofernes rein Subjektive ist."68 In sum, then, the task of Transcendental-Philosophy, according to Schelling is "vom Subjektiven, als vom Ersten und Absoluten, auszugehen, und das Objektive

63F. W. J. Schelling, System Des Transzendentalen Idealismus, (Hamburg: Felix Meiner Verlag, 1962),p. ? (III, 340). The figures in parenthesis refer to the original section numbers of the text.

$$
\begin{aligned}
& { }^{64} \text { Schelling, System.... p. ? (III, 340). } \\
& 65 \text { Schelling, System..., p. } 9 \text { (III, 342). }
\end{aligned}
$$

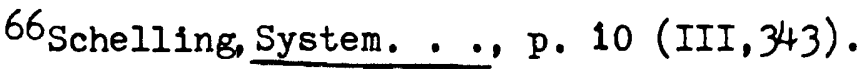

$$
\begin{aligned}
& \text { 67Schelling, System. ... p. } 12 \text { (III, 345). } \\
& \text { 68Schelling System. .. p. 12-13 (III, 345). }
\end{aligned}
$$


aus ihm entstehen $\mathrm{zu}$ lassen."69 Starting with subjectivity, Schelling seeks to derive his whole system of knowledge from the principle of consciousness, or ego, which he considers to be the dynamic or inner principle at work in Nature. The task of the transcendental philosopher is to present "das ursprüngliche Entstehen des BewuBtseins"70 and, therefore, for Schelling, philosophy is truly "eine Geschichte des Selbstbewußtseins, die verschiedene Epochen hat, und durch welche jene Eine absolute Synthesis sukzessiv zusammengesetz wird."71 Although the consideration of the history of consciousness is essentially analytical, involving theoretical, practical, and aesthetic aspects, Schelling is insistent that it is all, in effect "Ein absoluter Akt" including "nicht nur das Ich selbst mit allen seinen Bestimmungen, sondern. . .auch alles andere gesetzt, was fïr das Ich überhaupt gesetzt ist."72

These brief comments on Schelling's System..., its task and methodology, help, to understand Baur's transition from his basic supernatural stance evidenced in his book review of 1818, to a more open speculative approach first explicit in his Symbolik und Mythologie... of 1824-25. When Baur first came into contact with Schelling's work (probably around 1817 while a professor at Blaubeuren), he still maintained a supernatural concept of Christianity with its emphasis on its objectivity. Within this concept was rooted the idea of the Deus ex Machina, from whom man can but receive revelation but not rationally attain it. This, as noted

$$
\begin{aligned}
& \text { 69 Schelling, System.... p. } 10 \text { (III, 342). } \\
& 70 \text { Schelling, System...., p. } 64 \text { (III, 398). }
\end{aligned}
$$

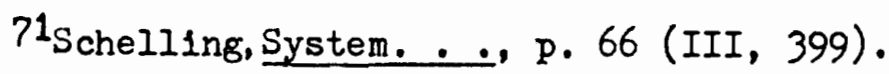

$$
\begin{aligned}
& 72 \text { Schelling, System..., p. } 55 \text { (III, 388). }
\end{aligned}
$$


earlier, polarized Subject and Object and resulted in an essential dualism in all knowledge in which nature and supernature were seen to war against one another. Schelling's System... was the intellectual yeast in Baur's mind which finally resulted in his rejection of his supernatural stance and its attendant dualism. The work had an almost inestimable influence on Baur who wrote of it to his one time student Ludwig Bauer, in 1822:

Ohne Zweifel wird Sie bereits Schellings wenigstens ungleich lebendigere und phantasiereichere Philosophie mehr angezogen haben, und ich rathe Ihnen besonders sein System des transcendentalen Idealismus, eine Schrift die mir vorzüglich gefallen hat, sorgfältig durchzulesen. Sie werden finden, daß Sie diese Schrift auch noch für Fichte entschädigt, und daß man durch sie sich hauptsächlich den wahren Begriff von der streng wissenschaftlichen Konstruction eines Systems bilden kan. Ich wei $B$ keine Schrift, die man nach Fichte's Wissenschaftslehre mit gröserem Nuzen für die besonders formale philosophische Bildung lesen kan.?3

Schelling's ideas and basic methodology, according to Hester, became the very foundation of all Baur's work beginning with the Symbolik und Mythologie. . :

In seinem ersten Werk sieht Baur--im Einklang mit Schelling-die Idee der Einheit des Wissens im Organismus des menschlichen Geistes vorgebildet. Diesem idealen Typus näherzukommen, ist auch für Baur das wahre Ziel des wissenschaftlichen Strebens. Die Frage nach dem Verhältnis einer äuBeren Autorität der offenbarung zu den freien, selbstbestimmenden Tätigkeiten des Geistes, nach dem Verhältnis der äußeren Geschichte zu den inneren Entwicklungen des Selbstbewußtseins--ihr begegnen wir immer wieder in den Schriften Baurs. 74

73 This letter has been published along with another addressed to I. Baver probably dated c. 1823/24 in Carl Hester, "Gedanken zu Ferdinand Christian Baurs Entwicklung als Historiker anhand zweier unbekannter Briefe", Zeitschrift fïr Kirchengeschichte (84. Band, 1973, Heft 2-3) S. 249-269.

74 Hester, "Gedanken. . . " p. 265. In this article Hester suggests that Baur's reliance on Schelling's idealism caused him to misread Schleiermacher on a fundamental point and that, therefore, "man kann nur sehr bedingt vom EinfluB Schleiermachers auf Baur. . . sprechen."(p. 264$).$ 


\section{Schleiermacher}

Notwithstanding the tremendous impact which Schelling had upon Baur, it was Friedrich Ernst Daniel Schlelermacher (1768-1834) who probably had the greatest influence on his theological thought. This fact was at least hinted at by Baur in the preface to his Symbolik und Mythologie... when he admitted his dependence upon Schleiermacher's thought without saying anything of Schelling's influence. Baur's silence concerning Schelling's influence upon him is almost incomprehensible in the light of the enthusiasm with which he recommended the System des Transzendentalen Idealismus to Ludwig Bauer in 1822, yet the impact of Schleiermacher's ideas on him may have been so strong at the time of the writing of the Symbolik und Mythologie... that it obscured the real debt which he owed to Schelling. Later Baur became totally disgusted with Schelling's ph1los ophy .75

Schleiermacher was, like Schelling, affected by the French Revolution and supported the German position, specifically the Prussian position, through sermons and through service as chaplain of the Charite Hospital in Berlin. Later, during the Napoleonic wars, he became even more active in an underground resistance movement in Germany made up of young patriots. He became manager of a small paper entitled The Prussian

75After many years in retirement, supposedly developing some new philosophy, Schelling came to Berlin where Baur heard him. For Baur, this occasion was disappointing to say the least, and he wrote to his friend Heyd about it, on November 30, 1841: "Es ist doch en beispielloser Hochmuth, mit welchem dieser Mann auftritt. Es ist ja, wie wenn er nur dazu nach Berlin gekommen wäre, um Hegel auf seinem Grabe zu verhohnen. Selbst sein bisheriges Stillschweigen soll nur als Hochmuth anzusehen seyn. Ich hofe dieser Hochmuth kommt nur vor dem Fall, und sage im Namen Hegels: Exoriare aliquis." 
Correspondant which published articles and editorials dealing with the German war effort. Often the zeal of 1ts contributors got the paper in trouble with even the Prussian authorities.

Although Schleiermacher had earlier shown definite leanings toward Romanticism, it wasn't until he came to Berlin that he became associated with the formal Romantic Movement represented by a circle of writers and poets, the most outstanding of which was Friedrich Schlegel. It is because he lived in their world and spoke their language, that Schleiermacher is to be associated with Romanticism in general. But, as Redeker has indicated: "That he was neither a poet nor an aesthete, can be seen from his own unfinished poetic efforts undertaken at the prompting of his friends."76 It was upon the subject of religion that Schleiermacher vented his frustration with the Enlightenment and Rationalism and showed himself to be a true child of the Romantic Revolt. This was clearly seen in his first major work: On Religion: Speeches to its Cultured Despisers which appeared in 1799. Its aim, according to Rudolph Otto, was:

to recapture the position religion had lost in the intellectual world where it was now threatened with total oblivion. It aimed to lead religion out of the remote corner into which it had been cast, to prove that religion was not just a concern of the "uncultured" and of old-fashioned people who found in it an emergency substitute for the higher things of life, but something that belonged to truly cultured, authentic, and well-rounded human beings; moreover, that without religion the intellectual life of mankind would deprive itself of its noblest ingredient. The book had been written for the purpose of restoring religion as a prime factor in the growth and further development of the

76 Martin Redeker, Schleiermacher: Life and Thought Trans. John Wallhauser (Philadelphia Fortress Press, 1973), p. 33. 
modern age.7?

In this work, Schleiermacher laid down his basic ideas on religion which were to be further elaborated in later works. Schlelermacher's concept of religion was opposed to both supernaturalism and the natural religion concept even though the objection to supernaturalism is implicit in his work while his objections to natural religion is explicit. The super natural view-point of orthodox Protestantism was no longer tenable for him because Western man's conceptualization of reality and his way of apprehending it had been revolutionized, primarily through the work of Kant. The growth of science and speculative philosophy too, were symptomatic of a change that had overtaken the Western world. The emphasis in Western thought was no longer the dualistic view of the God outside the machine who miraculously communicated to man from above, but rather, a system of natural causes in a closed system in which reality is understood through antecedent events. Thus, e1ther God was to be found in the increasingly shrinking realm of the inexplicable, and the dualism remained intact, or, as Schleiermacher proposed, God is to be found within a "higher realism" whereby all dualisms are comprehended by a greater unity. Ultimately, for him, religion is the feeling of absolute dependence before the universe, though that is not his terminology in the Speeches. He writes:

Religion neither seeks like metaphysics to determine and explain the nature of the Universe, nor like morals to advance and perfect the Universe by the power of freedom and the divine will of man. It is neither thinking nor acting, but intuition and feeling. It will regard the Universe as it is. It is reverent attention and submission, in childlike passivity, to be

77 In the introduction to Friedrich Schleiermacher, on Religion: Speeches to its Cultured Despisers, trans. John Oman (New York: Harper and Brothers, Publishers, 1958), p. ix. 
stirred and filled by the Universe's immediate influences. To metaphysics, man is the centre of all, the condition of all existence; to religion, he is, like every other finite thing, but a manifestation of the Universe. Morals proceeds from the consciousness of freedom and seeks to expand the realm of freedom to infinity: religion regards man as needing to be what he is, whether he will or not. 78

For the same reasons that supernaturalism in religion must be abandoned, so must the subjective approach of the rationalists be dropped. Not only does it fail to apprehend the essence of religion but it fails to do justice to the Universe itself. On this, he writes:

What, then, shall become of the highest utterance of the speculation of our days, complete rounded idealism, if it do not again sink itself in this unity, if the humility of religion do not suggest to its pride another realism than that which it so boldly and with such perfect right, subordinates to itself? It annihilates the Universe, while it seems to aim at constructing it. It would degrade it to a mere allegory, to a mere phantom of the one-sided limitation of 1 ts own empty consciousness.79

Overall, Schleiermacher wishes to show that religion is not something imposed upon the human race externally but rather a capacity or intuition within man which is a vital part of his life. To despise it is in reality to despise man himself. Even the essence of the Christian faith is already existing immanently within the human breast, more specifically in the consciousness of the subject, and is intimately connected with human reason which is a form and modification of an absolute religious consciousness. Thus, what is important in religion is not the external elements of the doctrinal corpus nor the learning and appropriation of these, but rather the heightened intuition of the Universe as a whole. It was this same consciousness which made Jesus Christ so important. 78 F. Schleiermacher, On Religion..., p. 277. 79 F. Schleiermacher, On Religion.... p. 40. 
This consciousness of the singularity of His knowledge of God and of His existence in God, of the original way in which this knowledge was in Him, and of the power thereof to communicate itself and awake religion, was at once the consciousness of His office as mediator and of His divinity. ... With this faith in Himself, who can wonder at His assurance that He was not only a mediator for many, but would leave behind a great school that would derive their religion from His? 80

Schlelermacher gave more mature expression to his ideas in his later works even though his Speeches. . contain his essential ideas. He also became more systematic in his presentation as The Christian Faith (1821/22) and the Glaubenslehre (1822) demonstrate. It was through these later works that Baur became familiar with Schleiermacher's ideas.

Baur first makes mention of Schleiermacher's Glaubenslehre in a letter to his brother Friedrich August Baur dated July 26, 1823 in which he mentions that he had studied the work carefully and was very impressed by it even though he could not fully comprehend $1 . .81$ Baur went on to try to give his basic points of agreement and disagreement on the work from both a philosophical and theological point of view. From a philosophical point of view, Baur considers the Glaubenslehre as both pantheistic and idealistic, and he criticizes Schleiermacher at this point:

Idealistisch ist vor allem die stete Entwicklung aller Hauptmomente aus dem Selbstbewußtsein, pantheistisch ist namentlich die Behandlung der Lehre von Gott, welche zwar Gott als das Absolute im reinsten Sinne setzt, aber zugleich mit solcher Abstraktion, daB nicht sowohl das Wesen Gottes als vielmehr die allgemeinsten Eigenschaften (ungefähr dieselben, auf welche Spinoza nach der Unterscheidung zwischen Sein und Denken oder Wissen alle übrigen Begriffe zurückführt) in Erwagung gezogen werden, und um jeden endlichen Gegensatz im göttlichen Wesen auszuschließen, auch nicht mehr von elgentlicher Personlichkeit

80F. Schleiermacher, On Religion..., pp. 247-248.

${ }^{81}$ The letter is published in full in Heinz Iiebing, "F. C. Baurs Kritik an Schleiermachers Glaubenslehre", Zeitschrift fur Theologie und Kirche, LIV: 2 (1957), pp. 225-43. 
die Rede sein kann. Selbst der Begriff der Gelstigkeit Gottes wird mehr nur in einem negativen Sinn genommen, und der einzige positive Begriff, der Gott beigelegt wird, ist nur der der Ursächlichkeit im allgemeinsten Sinn. 82

This objection to Schlelermacher's method is an important one for beginning to understand Baur's ideas on the Absolute synthesis between Bubjective and Objective existence. He is in agreement with Schleiermacher that such a synthesis is necessary, but he rejects his God-concept as too amorphous and vague to provide any real meaning for religion and especially Christianity. In Schleiermacher's system, consciousness is the important locus of religion and as long as one maintains this consciousness of the Universe in all its variety, then an affinity with Jesus is established existentially and he becomes the mediator of religion. But, Baur objects to this beginning with consciousness alone. He wishes to start with history because consciousness alone will lead to relativity. This brings him to the theological side of his critique, 1.e., a consideration of "wie fern dieses System den Charakter elner übernatürlichen Offenbarung im Christentum anerkennt." It was especially over Christology that Baur diverged from Schleiermacher. On the one hand, says Baur, he upholds that "die göttliche und menschliche Natur waren in thm verbunden, sofern das GottesbewuBtsein in Ihm ein wahres Sein Gottes war."83 But, Baur writes further, on the other hand, "wird in Inm ein Urbildliches und Geschichtliches unterschieden, und er selbst heibt die vollendete Schöpfung der menschlichen Natur." 84 Although Baur admits that he

$$
\begin{aligned}
& \text { 82 H. Llebing, "F.C. Baurs Kritik. . ."", p. } 238 . \\
& \text { 83H. Llebing, "F.C. Baurs Kritik. . .," p. } 242 . \\
& \text { 84H. Liebing, "F.C. Baurs Kritik. . .," p. } 242 .
\end{aligned}
$$


is uncertain of what Schlelermacher means by his discussion of Christ's "urbildilches und geschichtliches" existence, he still expresses concern that Schleiermacher has ultimately siighted the importance of the historical Jesus:

Wenn die Hauptmomente, dife die Person des Erlösers betreffen, selbst auch aus dem religlösen Selbstbewußtsein abgele1te werden, somit die außere Geschichte Jesu als eine Geschichte der innern Entwicklungen des religiösen Selbstbewußseins genommen werden, so kann ich mir die Person Christi als des Erlosers nur als eine gewisse Form und Potenz des Selbștbewubtseins denken, die nur darum in einer äußeren Geschichte erschien, weil die natïrliche Entwicklung des Selbstbewußtseins in inrer hochsten Vollf endung sich notwendig einmal so gestalten muß. Christus ist also In jedem Menschen, und die außere Erscheinung Jesu 1st auch hier nicht das Ursprungliche, sondern in dem Geschichtlichen soll nur das Urbildiliche, Ideale nachgewiesen, und das innere Ber.: wußtsein zur klaren Anschauung gebracht werden. 85

Baur recognized that Schleiermacher had dealt with the antithesis of rationalism and supernaturalism through transcending both, but in so doing, Baur believed that another crucial problem was raised. Schleiermacher's attempt at a rational/supernatural synthesis was carried out subjectively. According to Baur, this can only end by forshortening the "historical element" specifically in regard to Christology.

Baur's recognition of this shortcoming in Schleiermacher's philosophy marks a crucial point in his intellectual development. Here, as Ilebing has indicated, "Baur's theological question is turned into the question of history." 86 Thus, from his earllest work, Baur became increasingly concerned with histary, albe1t, not with the mere facts of history. It was with the meaning of history that Baur was concerned. In the preface to his Symbolik and Mytholggie...., he wrote: "W1thout

85H. Llebing, "F.C. Baurs Kritik. . ." p. 242

86 Heinz Liebing, "Historical-Critical Theology," trans. Peter C. Hodgson, Journal for Theology and the Church, 3 (1967), p. 60 
philosophy, history remains for me eternally dead and dumb." Taken by themselves, the facts of history could only present a tremendous conglomerate of values and multiplicity of separate phenomena, (collectively meaningless) with no continuity. What was necessary, according to Baur, was a philosophy which would cause these facts to live and speak. But the question remained, 'what philosophy?'. Certainly it had to be for Bawr an idealistic philosophy, but an idealistic philosophy which could transcend the dualism of subjectivity and objectivity. Schelling and Schleiermacher were approaching such a philosophy in Baur's view, but they had begun from too subjective a viewpoint. Baur's quest was to discover a philosophy which would allow history to speak without swallowing up its individuality in general forms and principles. In the Symbolik und Mythologie.... Baur was froping for such a philosophy. He wrote:

The idea conditions the individual manifestations everywhere. Without idea of religion, the nature of the individual forms of religion cannot be grasped. Again, how can the principle and character of a particular form of religion be rightly understood, if all manifestations of the same kind are not considered in their reciprocal connection?8?

Although Baux was not yet acquainted with Hegel's philosophy, ilt is evident that he was working towards something like it in the Symbolik und Mythologie..., and in his works. The main question with which Baur was warking was the discovery of a philosophy which would make sense out of historical facts without doing violence to their historical individuality. His problem was to find a model whereby their relationship might be partrayed as a unity. Ultimately, it was in Hegel that Baur found his philosophical key to history. The fey was the Absolute Spirit which carried within itself both subjectivity and objectivity, 87H. Liebing, "Histarical-Critical Theology," p. 60. 
both consciousness and historicity, both idea and reality.

$\underline{\text { Hegel }}$

G. W. F. Hegel (1770-1831) grew up in the revolutionary environment of Europe with the French Revolution, the Napoleonic Era, the rise of Romanticism and the continental revolutions in 1830. Although he has often been interpreted as an optimist, Hegel never viewed history as a cumulative stary of happiness, nor that happiness was just around the historical corner. Rather, he was surrounded by grief and seemed to be deeply touched by its presence. There was his friend Hölderlin, perhaps the most fifted poet of his generation, who gradually went insane and wasted away until his death. His only sister lived on the threshold of madness for most of her life and his only brother was killed in the Napoleonic wars. These personal tragedies combined with the revolutionary uncertainty of his own time to cause him to reflect on the meaning of history and to say: "History is not the soil of happiness. The times of happiness are empty leaves in $1 t . " 88$ According to Wilhelm Dilthey, Hegel was Impressed and Influenced by the French Revolution in a unique way:

Die souveräne fortschreitende Vernunft wie sie die Seele der kantischen Phllosophie, war, schein ihm in der Revolution am Werke, endilch thre Herrschaft zu verwirklichen. Welche ein Erlebnis lag in ihr für den kopf, welcher bestimmt war, die Geschichte als die Entwicklung des menschlichen Geschlechts zur Freiheit zu begreifen! 89

In spite of its uncertainty and tragic character, Hegel came to view

88 Quoted in Walter Kaufmann, Hegel: A Reinterpretation (New York: Doubleday and Company, Inc., 1965), p. 253.

89 W. DIlthey, Gesammelte Schriften, Vol. IV., p. 13. 
history as a rational process which he 1dentified as "none other than the progress of the consclousness of freedom"90 and more specifically as "the exhibition of Spirit in the process of working out the knowledge of that which it is potentially."91 Idea and history function together in bringing this process to completion.

The destiny of the spiritual World, and,--since this is the substantial World, while the physical remains subordinate to it, $a r$, in the language of speculation, has no truth as against the spiritual,--the final cause of the World at large, we allege to be the consciousness of its own freedom on the part of Spirit, and 1pso facto the reality of that freedom. 92

Hegel goes on to identify this "destiny of the spiritual world" with God's purpose for 1t:

This final aim is God's purpose with the world; but God is the absolutely perfect Being, and can, therefore, will nothing other than himself--his own Will. The Nature of His Will--that is, His Nature itself--is what we here call the Idea of Freedom; translating the language of Religion into that of Thought. The question, then, which we may next put, is: What means does this principle of Freedom use for its realization?93

The means by which Spirit comes to a consciousness of its own freedom is Histary itself. According to Hegel, although Spirit or the spiritual World is the truly substantial World, Spirit remains merely general and abstract "principle, aim, destiny" unt1l it finds its actualization in History and thereby enters fully into the realm of reality. The means by which Spirit enters into historical existence is through human interest or passion. Thus, he writes, in addition to ideas

A second element must be introduced in order to produce actuality--viz. actuation, realization; and whose power is the Will--

$90_{\mathrm{G}}$. W. Hegel, Lectures on the Philosophy of History (London: George Bell and Sons, 1902), p. 19-20.

$$
\begin{aligned}
& 91_{G} \text {. W. F. Hegel, Lectures...., p. } 18 . \\
& 92_{G} \text {. W. F. Hegel, Lectures.... p. } 20 . \\
& 93_{G} \text {. W. F. Hegel, Lectures...., p. 20-21. }
\end{aligned}
$$


the activity of man in the widest sense. It is only by this activity that that Idea as well as abstract characteristics generally, are realized, actualized, for of themselves they are powerless. The motive power that puts them in operation, and gives them determinate existence, is the need, instinct, inclination, and passion of man. 94

Therefore, in Hegel's phllosophy, both Idea and Histary are considered as two aspects of reality, yet, while they are differentiated, they are not separated dualistically. Rather, combined, they form reality itself. "Two elements, therefore, enter into the object of our investigation; the first, the Idea; the second, the complexity of human passions; the one, the warps the other, the woof of the vast arras-web of Universal History." 95

Christianity plays an important part in the process of Spirit coming to self-realization. Christianity is presented primarily as Idea which is born historically out of the Hellenistic-Roman milieu. For the Greeks, the law for their Spirit was: 'Man, know thyself!' This is a consciousness of Spirit, but it still remains objectified in their divinities and in their art where the sphere of the sensuous "Is elevated only to the middle ground of beautiful form and shape, but not to pure thought." 96 The Romans bring to consclousness the subjectivity which ils lacking to the Greeks although it is only formal and in itself indefinite, taking "Its material from passion and caprice."97 The Romans respond to the striving of subjectivity and objectivity through the concept of submission

$$
\begin{aligned}
& 9_{4} \text {. W. F. Hegel, Lectures.... p. } 23 . \\
& 95 G \text {. W. F. Hegel, Lectures.... p. } 24 \text {. } \\
& 96 \mathrm{G} \text {. W. F. Hegel, Lectures. ... p. } 331 . \\
& \text { 97G. W. F. Hegel, Lectures. ... p. 331:. }
\end{aligned}
$$


to fate and duty. What is still necessary according to Hegel is:

He must feel himself as the negation of himself; he must see that his misery is the misery of his nature--that he is in himself a divided and discordant being. This state of mind, this self-chastening, this pain occasioned by our individual nothingness--the wretchedness of our (isolated) self, and the longing to transcend this condition of soul--must be looked for elsewhere than in the properly Roman World. 98

This state of mind is finally reached by the Jewish People. Here, "Spirit came to absolute self-consciousness--passing from that alien form of belng which is its discord and pain, and mirroring itself in its own essence."99

At this stage the joy of reconciliation is still distant from human1ty. There is only the awareness of allenation, the comprehension and reconciliation of subjectivity and objectivity is as yet undiscovered. Yet, at this stage, "the fullness of time" has come and reconciliation is expressed through the Christian trinity and particularly in the God/man. "Christ has appeared, --a Man who is God,--God who is man; and thereby peace and reconciliation have accrued to the World."100 He continues:

Man himself therefore is comprehended in the Idea of God, and this comprehension may be thus expressed--that the unity of Man with God is posited in the Christian religion. But this unity must not be superficially conceived, as if God were only Man, and Man, without further condition, were God. Man, on the contrary, is God only insofar as he annuls the merely Natural and Iimited in his Spirit and elevates himself to God. That is to say, it is obligatory on him who is a partaker of the truth, and knows that he himself is a constituent (Moment) of the Divine Idea, to give up his merely natural being: for the Natural is the Unspiritual. In this Idea of God, then, is to

$$
\begin{aligned}
& 98_{G} \text {. W. F. Hegel, Lectures. ... pp. 332-333. } \\
& 99_{G} \text {. W. F. Hegel, Lectures.... p. } 333 . \\
& 100_{G} \text {. W. F. Hegel, Lectures.... p. } 336 .
\end{aligned}
$$


be found also the Reconciliation that heals the pain and inward suffering of man. 101

This annuling of the "merely Natural and Iimited" was accomplished first by Jesus Christ but it is only after his death that he achieves significance for his followers as "an object for their truly spiritual consciousness."102 Hegel sidesteps the question of Christ's substitutionary atonement, his superior person, and the question of miracles, as unimportant for his discussion because, in his estimation, it all ignores the conception of the Speculative Idea, of Absolute Truth. "The main question;" he writes, "Is not his Divine Mission, but the revelation made in Christ and the purpart of his mission."103

It is fairly clear why Hegel's ideas attracted Baur's attention as an adequate philosophy of history. Even before Baur's acqualntance with this philosophy, he was already wrestling with many of the issues Hegel disguised in his philosophy. In his Symbolik und Mythologie, for example, Bawr had expressed his belief that history was incomprehensible outside of philosophy and had been toying with the concept of "Idee" in history as a clue to history's ultimate meaning. But up until Hegel, Baur was not comfortable with Idealistic interpretations because they tended to dissolve the particulars of history into general abstractions. In Hegel, however, Bawr found a philosophy which brought Idea and History together and presented an answer to the question of how philosophy could bring history to Iife and make it speak. Hegel brought Baur to understand

$$
\begin{aligned}
& { }^{101} \text { G. W. F. Hegel, Lectures.... p. } 336 . \\
& 102 \text { G. W. F. Hegel, Lectures._... p. } 337 . \\
& 103 \text { G. W. F. Hegel, Lectures...., p. } 338 .
\end{aligned}
$$


"1dea" as a process of Spirit which proceeds in conformity with Spirit, and thus he began to understand history as philosophy, since it follows an idealistic course, and philosophy as theology since that course is determined by God's purpose for the world. "In Hegel's system", wrote Baur, "It (theology) has overcome its antithetical stand toward philosophy, which has prevalled since the end of the Mlddle Ages, and has returned to the unity of spirit." 104

Yet for all that Baur learned from Hegel, (and that was a great deal) he never read him as a philosophia perennis nor did he ever apply Hegelian catagories upon history in any a priori fashion. Ironically the very aspect of Hegel's philosophy which attracted Baur also became the aspect of divergence between them. The possibility of taking history seriously provided by Hegel's philosophy attracted Baur as opposed to the overly subjective approaches of Schelling and Schleiermacher. Yet within Hegel's philosophy was a latent distain for historical details in contrast to Idea. The breakd own of the Hegelian synthesis in the nineteenthicentury was a natural outcome of this latent distain. Baur seems to have had a greater concern for history than Hegel and hence paid increasingly more attention to it in his writings. The question of the meaning of the historical Jesus became the most clear locus of divergence between Baur and Hegel.

Baur's Christology

Although Hegel attempted to hold the positivity of history and the subjectivity of reason together in synthesis, he demonstrates a preference towards Ideality in his conception of Christ. Hegel's Christology is

104quoted in H. Llebing, "Historical-Critical Theology," p. 68. 
ultimately docetic in nature because he separates the meaning of Christ's coming from his actual earthly life. What is left is a Christ of faith and a Jesus of history which results theologically in histaricity being swallowed up by falth. Baur accepted Hegel's basic concept of the relation of idea and history, his idea of reconciliation being worked out in the process of history, his concept of passion (conflict) as the dynamic of history, and even his assesment of the nature of theilncarnation and atonement in the person of Christ. But what he could not accept in Hegel's philosophy was his docetic Christology, 1.e. his tendency to deny any special significance to the historic Jesus. That is because, according to Baur, Christianity is incomprehensible outside of 1ts founder. But Baur's reason for seeking to maintain the historicity of Jesus is not to present an orthodox position based upon an historic revelation, nor, specifically, to avoid docetism in his theology. Rather, it is because he wishes to understand Christianity historically and believes that Jesus is its sine qua non historical antecedent. In his wark on the early Ohurch he writes, "When we consider the way in which Christianity grew up, it is plain that it could have had no place nor significance in history but for the person of its Founder."105 The significance of Jesus for Christianity, according to Baur, can not be as an absolute iniculous beginning of a supernatural revelation. That idea does violence to any historical consideration of Christianity, indeed it lifts it above any historical comprehension whatsoever. On this important idea, Baur writes:

The historian who approaches his subject imbued with the faith

105F.C. Baur, The Church History of the First Three Centuries trans. Allen Menzies (London: Williams and Norgate, 1878), p. 38. 
of the Church finds himself confronted at the very outset with the most stupendous of miracles, the fact which lies at the root of Christianity being in his eyes that the only-begotten Son of God descended from the eternal throne of the Godhead to the earth, and became man in the womb of the Virgin. He who regards this as simply and absolutely a miracle, steps at once outside of all historical connection. Miracle is an absolute beginning, and since as such it must needs qualify all that follows, the whole series of phenomena which fall within the range of Christianity must bear the same miraculous character. Historical connection having once been severed at the outset, the same interruption of the historical process is equally ! passible at any further point. 106

If Christianity is to be considered histarically then every point of its existence must find its root in history, including Jesus Christ himself. But the question naturally arises: 'How does he avoid making Christianity merely a particular historical phenomenon no different than say, Stoicism or Cynicism?' Baur found his solution to this question in Hegel's philosophy which allowed him to step out of the dualistic natural/ supernatural dichotomy and to concelve of both Idea and Histary as int1mately connected. Idea, specifically the Idea of reconciliation which is the preeminant theme of history for Baur, must find its actualization in History, thus, Idea and History are intimately connected. But, at the same time, Idea never find its absolute realization in History for that would bring History to an end and destroy the dialectical relationship of Idea and History. Therefore, Christianity is truly a fully historical manifestation Iike Stoicism or Cynicism, but it is superior to them by virtue of its greater historical actualization of the idea of reconciliation. This idea of reconciliation is clearly present in the consciousness of Jesus but the transmission of this consciousness to his disciples and on to Christendom comes only through his death on the cross. 106F. C. Baur, The Church History. ... p. 1. 
As Baur examines the gospels and the teachings of Jesus, he finds In them the consciousness of reconciliation most explicitly in the moral realm. On this point, he writes:

If the Christian is conscious of his absolute standpoint, he must be able to abstract from himself, from his own ego, and to know himself as so much one with all others, that he regards each other man as one who possesses equal rights with himself. And this is what Jesus means when he says of the requirement we are speaking of, that $1 t$ is the law and the prophets, or equivalent to the old Testament command, "Thou shalt love thy neighbour as thyself." He who loves his neighbour as himself must renounce everything egotistical, subjective, or peculiar to himself; above the purality of separate subjects, each of whom now is the same as we are, there comes to stand the objective universal, where everything particular and subjective is done away.10?

This impulse towards the "objective universal" 1s, for Baur, the most characteristic feature of the original Christian principle which is reconclliation." "It looks beyond", writes Baur further, "the outward, the accidental, the particular, and rises to the universal, the unconditioned, the essential."108 In short, the ethical teaching of Jesus is the principle of reconcillation translated into ethics for it, "asserts itself in the demand to do away with the individual ego by raising it up to the universal ego, the general self, that humanity which is present and is identical with itself in every separate individual." 109

But as lofty and noble as these moral precepts are, they would not have entered into general consciousness had it not been for their incarnation in Jesus. Baur writes:

How soon must all the true and weighty precepts of Christianity have been numbered with the faint echoes of words spoken by many

$$
\begin{aligned}
& \text { 107F. C. Baur, The Church History. .., pp. 32-33. } \\
& \text { 108 F. C. Baur, The Church H1story. ... p. } 33 .
\end{aligned}
$$

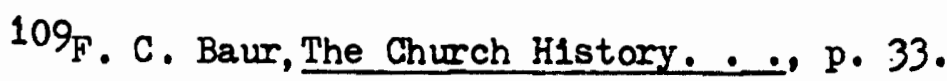


a friend of humanity and philosophic sage of ancient times, had I: not its doctrines been made words of etermal life in the mouth of its Founder? 110

It was the belief of Jesus followers that he was the Messiah, which made the later birth of Christianity possible, i.e., allowed it to enter on the path of historical development. From this beginning, "the consciousness of Jesus was thus taken up by the national conseiousness, , and enabled to spread and become the general consciousness of the world. "111

Baur never conceives of Christianity as suddenly being born. It is rather, the unfolding of an idea which comes to gradual historical realization. Every step in this development has its place of importance In the historical chain and every step is fully historical in nature. There is, for Baur, no Invasion of the Deus ex machina into nature or history. This conception of the rise of Christianity determines Baur's understanding of the resurrection which he considers as a vital link in the historical chain, but not a powerful enough event in itself to give rise to the Church. On the occasion of Jesus death, he writes:

Only two alternatives were possible: either with his death the faith which had gathered round him must be extinguished, or this faith, if it were firm and strong enough, must break through the barrier of death itself, and force its way from death to life. Nothing but the miracle of the resurrection could disperse these doubts which threatened to drive away the faith of the disciples after its object into the eternal night of death.112

Baur will not discuss the nature of reality of this "miracle" since that "Iles outside the sphere of historical enquiry."113 In any case, he

110F. C. Baur, The Church History. .., p. 38.

111 F. C. Baur, The Church History. . . p. 39.

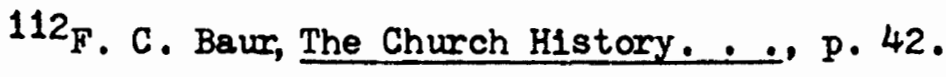

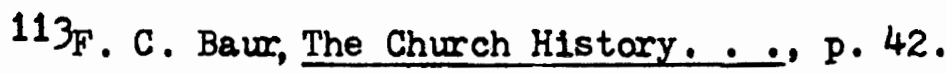


notes: "the view we take of the resurrection is of minor importance for the history."114 What is important, however, is that "the resurrection of Jesus became a fact of their consciousness, and was as real to them as any historical event." 115

Notilthstanding the importance of the resurrection event, Baur still believes it was too narrow to produce the universality of Christian1ty and the Church. He writes:

Had no new development taken place, the only difference between the believing disciples and their unbelleving fellow-countrymen would have been that to the former the Messiah would have been one who had come already, and to the latter one who was still to come. The christian faith would have become the faith of a mere Jewish sect, in whose keeping the whole future of Christianity would have been imperilled.116

What made the difference, in Baur's mind was the dialectical conflict in which the disciples engaged after his death. It was none other than the struggle between Paulinism and Judaism, which Baur first belleved he had discerned in the Corinthian epistles, that brought Christianity to its epitomic development as the universal principle of salvation through a synthesis of Paulinism and Judaism in the Idea of the Catholic Church. In sum, then, according to Baur, the historic Jesus is essential to Christianity as the historical embodiment of its original principle. which is reconciliation. Jesus is fully historical and, therefore, cannot be the absolute God-Man since the Ideal, while it finds its actuality

${ }^{114} \mathrm{~F}$. C. Baur, The Church Histary. ... p. 43.

115F. C. Baur, The Church History.... p. 43.

$116 \mathrm{~F}$. C. Baur, The Church History. .. p. 43. 
in History, must never be identified absolutely with $1 t .117$ This conception of the relation of Idea and History is born out in Baur's writing on the Trinity and Incarnation:

If the ldea once succeeds to its absolute existence in a single, definite individual, then not merely the drive but also the possibility of actualizing itself in other individuals is taken away from the 1dea. . .. It is therefore clear that one cannot absolutely say that the idea must become absolutely real in a single, definite individual. But the relationship of idea and reality also embraces in itself the element of distinction; and for this reason idea and reality can never be joined together in such absolute unity that the idea does not transcend every manifestation given in reality, indeed, every single individual; therefore the idea can actualize itself only in an infinite series of individuals. In every single individual the nonbeing of the idea must also be posited, be it only as a minimum. . .. As certainly as the idea of humanity must actualize itself, and as certainly as it is established essentially in the unity of God and man, just as certainly can it be actualized only by virtue of the fact that it enters into the consclousness of humanity at a definite point in a definite individual. However, no matter how highly in other respects one may place this individual, in virtue of the idea of this unity which comes to consciousness in him, he must still stand in a subordinate relationship to the idea, and a God-man in the sense of ecclesiastical doctrine embraces in itself an irresolvable contradiction. 118

Jesus is special because the idea of God-manhood is maximized in Him and, further, it is through Him that the idea of reconciliation finds historical reality and becomes a part of general human consciousness. It is by virtue of his heightened consciousness of the idea of reconciliation. He lives as but a man, in the flesh, yet his existence is not according

117The absolute Identification of Idea and History can only happen, of course, transhistorically, and as Hodgson has clearly percelved, this represents Baur's eschatology. (P. C. Hodgson, The Formation of Historical Theology, p. 105).

118quoted and translated in P. C. Hodgson, The Formation of Histortcal Theoliogy, p. 104-105, taken from F. C. Baur, Die Christliche Lehre von der Dreielnigkeit und Menschwerdung Gottes in inrer Geschichtlichen Entwicklung, Vol. III (Tübingen: C. F. Osiander, 1843), pp. 996-999. 
to the flesh because he lives consclously_eccording to to the Spirit. Christ's work therefore, is accomplished by bringing the consciousness of reconciliation to man by submitting himself to the Spirit. Atonement for him, is not a substitutionary death in satisfaction of a divine judgment, but rather the reestablishment of an estranged relationship. The resurrection means that "God was in Christ reconciling the world to himself". It is not important to ask of the nature and reality of that event, but only that one understand the meaning of the event and then to appropriate it by faith. Through faithful appropriation man enters into the unity first established in Christ. Thus, is the atoning work of Jesus efficacious to deliver man and it is the work of his followers to proclaim this kerygma. Beyond Christ is the Church which carries out the idea of reconciliation first demonstrated historically in Jesus, through historical continuation and development. The actualization of the idea of reconciliation is, indeed how the history of the Church is Interpreted by Baur as will be demonstrated in the next chapter. Yet, before proceeding from his Christology on towards his Church history, it must be emphasized here that the two areas are intimately connected. In fact, as Hodgson has stated, "the real clue to Baur's thought is his historically explicated Christology."119 For Baur, there was to be no separation of New Testament history and Church history. Christianity, for him, was a great historical chain whlch is still in the making, and therefore, the task of historlcal criticism is the awesome and religious undertaking of understanding the ongolng revelation of Spirit. Käsemann Indicates this fact in his introduction to Baur's Ausgewälte Werke:

119p. C. Hodgson, The Formation of Historical Theology, p. 213. 
Historisch-kritische Arbeit ist fïr Baur also offensichlich mehr als eine hándwerkliche Methode, namlich zutiefst religiöse Aufgabe und das Medium religioser Vergewisserung. Denn sie ist die sachliche Entsprechung der geschichtlichen Offenbarung als einer Anrede an den zum Glauben gerufenen Menschen, nämlich das adäquate Hören und Verstehen der Offenbarung, soweit sie bisher in der Vergangenheit erging. Historische Kritik ist die Funktion des lebendigen Glaubens auf seinem Wege aus bewußt gewardener Vergangenheit in die eigene Gegenwart und Zukunft, welche eben diese Vergangenheit in den übergreifenden Zusammenhang der Gesamtgeschichte stellt.120

In this statement, Käsemenn has captured the true spirit of Baur's theological and historical work. It was natural for Baur to arrive at a comprehensive treatment of Church histary at the end of his Iife. All of his work on the early Church brought him to a dynamic conception of history, to an awareness of history as a growing organism. The earlier works had convinced him that the message of Christianity, 1.e. reconciliation, had seen its beginning in Jesus, yet he did not believe the Chumch was simply a static institution born out of one single event. To him the Chumch was fully involved in the historic process and as such had its own distinct message in every successive epoch. The task of the historian of the Church and theology was to uncover that message, not only as it had occured in the past, , but as it was occuring in his own present as well. This conception of the Church became the foundation of his criticism of the writing of Church history and the formal basis for his own reconstruction of Church history.

${ }^{120}$ In the Introduction to F.C. Baur's Ausgewählte Werke vol. I, p. $\mathbf{x i x}$. 
BAUR ON THE HISTORIOGRAPHY OF

CHRISTIAN DOGMA AND THE CHURCH

Baur came to the consideration and writing of Church histary toward the end of his life, yet to a great extent,ihistory was the problem he was addressing throughout his entire career. It is only in the light of his overriding concern with history, that Baur's work is properly understood, and, further, all of his work prior to his actual treatment of Church history can be considered as the acquisition of equipment for this final crowning achievement. Otto Pfleiderer, one of Baur's earliest students, wrote in memory of him:

Baur war zum Historiker geboren: eine ungeheure Arbeltskraft, ein vortreffliches Gedächtnis, ein kritischer Verstand, der sich bel kelnen zweifel hasten Ueberlieferungen beruhigte, ein scharfer Spürsinn, dem auch die Bedeutung des scheinbar Kleinen nicht entging, und eine geniale Combinations gabe, die das Entlegenste zusammenzuschauen und in dem Mannigfaltigen der geschichtlichen Erscheinungen die Einhelt der beherrschenden Idee, den treibenden und leitenden Geist einer Zeit zu endecken wubte, --das war die Ausrüstung Baurs zu seinem Beruf als theologischer Kritiker und Historiker. 1

As has been eariler discussed, Baur was greatly indebted to three philosophers, Schelling, Schlelermacher, and Hegel, for his conceptual understanding of history and its relationship to Idea. From Schelling, Baur derived a fundamental perception of histary as revelation itself, ra perception which effectively began to undermine his earlier supernatural

1 Otto Pfleiderer, "Zu Ferdinand Christian Baurs Gedächtnis," Protestantische Kirchenzeitung fü das evangelische Deutschland, XXXIX: 25 (June, 1892), p. 566 
view-point. Schleiermacher's philosophy strengthened Baur in his idealistic views and taught hin to understand consciousness as the essence of religion. However, Baur never read elther of these philosophers uncritically, notwithstanding their tremendous influence upon him at his most formative stage of scholarly development. Later, Baur looked on the work of these two men as too subjective. From Hegel, Baur derived a model in which both History and Idea, both Subjectivity and Objectivity were considered in close relation without either taking precedence. Idea and History appeared in dialectical relationship to one another and together were considered as the means by which the development of the Sp1rit's self-consciousness becomes actual. For Baur, Hegel's model was the key for understanding the Church historically, and as Pfleiderer remarks, it was Baur's application of the Hegelian model to the Church and dogmatic development which "1st das epochemachende Verdienst Baurs."2 Still, as in the case of Schelling's and Schlelermacher's philosophies, Baur did not simply borrow Hegel's philosophy and use it a priori for his own purposes. He recognized that he could learn something from Hegel's speculative approach, and was therefore willing to listen to Hegel's views. But, at the sane time, both by admission and personal scholarly example, Baur demonstrated that his ultimate commitment was to the truth of the facts, particularly the historical facts, and that, further, he would not allow any overly-subjective speculative approach to obscure the facts of history. Thus, Baur's ldeas on Church history and histatical theology, while unquestionably influenced by the 1dealistic philosophies of Romanticism, are still uniquely his own, as Baur always 
sought to maintain his scholarly distance from a priori systems.

In considering Baur's historical theology and Chureh history, the following discussion will focus on two works of major importance, the Introduction to Lectures on the Histary of Christian Dogma, for his thought on the history of dogma, and The Epochs of Church Historiography, for his thought on the writing of Church history.3 In this chapter, the concern is not the actual production of Church history or historical theology, but rather Baur's conception of the historiography of these two flelds including such things as his general philosophy of history as applied to the church, but also, more practically, his periodization of Church historiography. His thought on the development of dogma will be treated first, since it represents his earlier thought, but also because he considers theology to be the inner key to an understanding of Church history.

\section{BAUR ON THE HISTORY OF DOGMA}

To begin with, Baur concelves of the history of dogma as but the Inner aspect of a historical individual, 1.e., Christianity whose outer aspect is the Church. History of dogma, therefore, is prior to the institutional Church and is placed above the institutional aspects of the Church since, "Everything external has its basis in the internal iffe from which it proceeds. ${ }^{4}$ Yet both the history of dogma and the

3 I will be using P. C. Hodgson's translations of these two works which are found in his book Ferdinand Christian Baur on the Writing of Church History. All quotation will be taken from this work, and will be c1ted as IHD for the Introduction to Lectures on the Histary of Christian Dogma and Epochs, for The Epochs of Church Histarlography. 
Institutional Church are considered as only different aspects of Church history. History of dogma is therefore defined as "that discipline which enables us to see into this inner aspect of Church life and which acquaints us with the course of the spiritual movement to which the external phenomena are attributable as their ultimate basis." 5 The inner aspect of the Church which Baur indicates here, is in no way a static principle like the Vincentian quod ubique, quod semper, quod ab ominibus creditum est. That is the very princlple Baur wishes to avold because of its fundamental supernaturalistic foundation. Rather, he considers the inner aspect of Christianity, 1.e. dogma, to be radically historical. Dogmatics always ends in the history of dogma, because each age has its own common consciousness and must therefore write its own dogmatics. He writes:

The inescapable fate of dogmatics is that it continually reverts to the history of dogma, which here discloses itself In its all-embracing power--a power that masters dogmatics. But dogmatics already appears in a dependent relation to the history of dogma because it cannot be orientated to 1ts substantial content--namely, what is publicly received and fixed in the total consciousness of the time--except from the standpoint of the history of dogma. It must have sufficiently broad recourse to history to obtain firm basis for itself. 6

Because the history of dogma is a continually flowing and changing historical phenomenon, it has not been written correctly until it has been traced up to its present form.

Just as history in its own objective course is a never-resting movement, so historical reflection and presentation cannot stop at any point until it has reached the final phase of development in the present. To terminate the whole at any earlier point that might be established would only be an arbitrarily determined suspension which in the nature of the case could not be justifled.?

That the appropriate terminus ad quem for a history of dogma is the

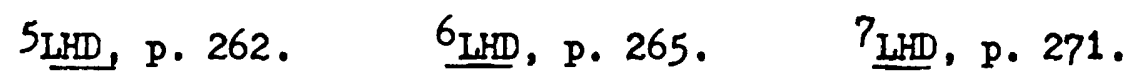


present does not mean that the past is unimportant, for the idea of Christianity has been working itself out in all periods of the history of dogma, and the individual stages of this past provide a perspective from which to understand the present.

Concerning the terminus a quo of the histary of dogma, Baur believes it begins with Jesus. But, as has been noted earlier, Jesus does not represent the absolute beginning from above, and thus the unchanging element within the temporality of the history of dogma. For although in Jesus the idea of Christianity finds its first concrete expression and thereby enters into history, this event does not happen from above. Rather, what Jesus teaches emerges out of history through his higher consciousness of Spirit, and, therefore, this teaching itself is a historical question.

This does not eliminate the concept of revelation, according to Baur, but rather reconceptualizes it to avoid the dualism attendent upon supernaturalism. Baur normally does not use the term "revelation" in his writings, no doubt because he fears he will be misunderstood. Yet, when he does ise $1 t$, it is in a special sense as the self-manifestation of the Absolute Spirit in and to the finite human spirit. "Religion itself," he writes, "Is essentially a relation of Spirit to Spirit, in which Spirit mediates itself with itself through the activity of thinking." 8 And further:

Revelation is an act of Spirit in which an objective reality oonfronts subjective consciousness as an immediate given, and becomes for the subject the object of a faith whose content is the Absolute Idea. Moved by the power of the Absolute Idea, the entire thinking activity of the subject feels the compulsion to become absorbed into this objective reality, given as an immediate 
divine power, in order to bring its content into consciousness-as it were, to lay it out in all its components for the representative consciousness. 9

Within this process there is a certain sense of givenness which can be classified as revelation but it is not the objective revelation of a God standing outside of the world who merely presents it to man. Man, because he finitely partakes of the Absolute Spirit, knows revelation through the historical manifestation of reconciliation in Jesus. Therefore, revelation is something which happens within history. This view, is akin to the romantic conception of religion as it was developed by Schleiermacher but Baur goes beyond him by drawing on Hegel and developing a concept of history as the concrete actualization of Spirit.

It is primarily his concept of revelation which allows for the possibility of religion apart from subjective philosophy, yet philosophy and religion are couterparts in the manifestation of Spirit. He writes:

Religion and philosophy, as two forms of the manifestation of Spirit, are implicitly identical in the nature of Spirit but are essentially different in the form of their manifestation. It is characteristic of religion that Spirit knows the truth which is the content of religion only as something received, something absolutely given--an external revelation which, even though it contains nothing in contradiction to thinking reason, nevertheless has at least its historical origin outside of reason; and on this account it exists only in the form of representation, as something immediate, which is not yet mediated with thinking consclousness. In philosophy, on the other hand, Spirit knows the truth as something immanent to 1tself, as the result of its own thinking. 10

Baur's basic critique of Schelling and Schlelermacher was centered upon their overly-subjective approach to truth. In his own terms, it was their over-mphasis on the finite human connection to Spirit. Religion, specifically Christianity, as Interpreted by Baur, however, corrects

$$
\text { 9LFD, p. } 298 .
$$


this imbalance by its assertion that the truth is not simply within man but rather comes to him apart from his subjective reason, in an historical event which confronts man's subjective consciousness isith truth of its own being. Thus, Christianity is the answer to subjectivism and brings subjectiviss in proper relation to object. According to Baur, it consists:

In a revolution out of subjectivity into the objective, into Being itself, 1.e., a return to God. Consequently, Christianity appeared in the world not as philosophy but as religion. As divine revelation in the form of religion it was something absolutely given, which in its immediacy could be the object not of thinking and knowing but above all only of faith. Thus Christian dogma has its starting point in faith. It is itself faith in a representational mode; and all thinking connected with dogma has its final, determinative principle pniy in faith, regardiess of how free it might otherwise be. 11

The above comments on Baur's concept of revelation represent his essential critique of rationalism. Ultimately, he sees it as too subjective and failing to properly relate itself to its object. On the other hand, Baur knows full well the danger of an overly-objective approach which can only lead to Confessionalism. This is preceisely why Baur opted for a speculative methodology. The process of dogma is both objective and subjective. It is objective because it is truth given to man's consciousness by the absolute truth of Infinite Spirit, a truth which is demonstrated in the historical person of Jesus Christ. It is subjective because the task of dogma is to translate bellef from mere assent into a faith response whereby absolute Spirit comes dialectically to greater self-knowledge through its encounter with finite Spirit. He writes:

The whole movement of dogma proceeds between two mutually opposing points, which should be brought together in the union of objectivity and subjectivity. On the one hand stands dogma in its objective truth before Spirit, whose task is to assimilate 
it into its subjective consciousness and to become ever more certain of its content; on the other hand, the absolute truth of dogma can only correspond to the equally absolute certainty of the subject within himself. Between these two poles the entire movement of dogma takes place as the unending work of Spirit struggling with itself, aspiring toward a free selfconsciousness in the absolute content of dogma. Every new configuration of dogma is a new attempt by Spirit to become more certain of truth, to take deeper and more comprehensive possession of the content of dogma.12

To sum up the discussion thus far, Baur holds a very broad view of the content of the history of dogma. He begins the history of dogma with the teaching of Jesus and the New Testament, because to set them apart as unchanging, as transhistorical, is to set a precedent for the severence of the historical process at st1ll a later point. This had been the major problem of the Catholic understanding of the history of dogma which, he says, considers the "external manifestation of dogma as the essence of the subject matter 1tself, whereas dogma can have its true, vital unity only in Spirit, which is objectified in dogma."13 On the other end of the histarical continuum, the terminus ad quem for the history of dogma is the present dogmatic situation. Thus, the history of dogma does not come to an end with the Refarmation, according to Baur. This is because, for him, dogma is not limited to the official creeds, confessions and symbols of the Church, but rather includes the whole histary of Christian thought. "The term "dogmas" means the doctrines or teachings of the Christian faith, insofar as they contain the absolute Christian truth."14 Therefore, the histary of dogma is an ongoing story because the idea of Christianity is still being historically worked out. This 1dea, and with it, the history of dogma, will only find 1ts telos

$$
12 \underline{L D}, \mathrm{pp} .305-306 \quad 13 \underline{\mathrm{LD}}, \text { p. } 362.14 \mathrm{LHD}, \text { p. } 269
$$


beyond histary. Baur belleves that Protestantism, in its opposition to Catholicism's objectivism, is always in danger of subjectivism. While both views have their individual strengths, neither is adequate in itself to produce a balanced conception of the hist of dogma. And that is why Baur presents his idealistic conception of the history of dogma, because in his thinking, it provides both for unity (the Catholic principle) and diversity (the Protestant principle). He writes:

Just as the Catholic view of history, in conformity with its principle, cannot move beyond the substantial unity of dogma, so on the opposite side the Protestant view could only lose the substantial unity of dogma by dissolving it into the endless multiplicity of individual representations and beliefs; the whole of the history of dogma appears to fall into subjectivity. An objective view of history can therefore only be one that remains equally far from the bias of both extreme and is able to conceive the two divergent tendencies in their inner freedom as two correlative sides of the same spiritual process. The more that further treatments of the history of dogma succeed in detecting this process, based on the nature of spirit, in the historical course of dogma, and in bringing it to clear perception, the more they will thereby fulfill their scientific conception.15

Baur believed that the development of Catholicism and subsequently Protestantism were but stages in the development of the synthetic conception of the history of dogma which, in his own day, was coming to realization. Thus, according to him, the very course of the history of dogma itself, apart from its intellectual substance, had meaning. He writes:

The entire history of dogma is a continual procession of Spirit in never ending conflict with itself, never able to become truly one with itself, it is a constant binding and loosening, a neverresting work in which Spirit, like Penelope, continually unravels its own web, only to begin again anew. No sooner does it impose

15This quote is taken from $P$. Hodgson, Ferdinand Christian Baur on the Writing of Church History, p. 363 in footnote $\$ 44$. It was taken and translated from Baur's Lehrbuch der christlichen Dogmengeschichte (3rd ed., Leipzig, 1867), pp. 55-58, and was probably written before Baur wrote his Lectures on the History of Dogma. 
upon itself a limiting and determining authority, thus binding itself, then it desires to be free, to withdraw from that authority. Whatever, under the compulsion of its internality, it has produced from ithin in arder to become objective to itself, w1ll at just that point have been outgrown. It will have become an external and alien force, and all the efforts of Spirit must now be directed toward reintegrating that force into itself, so as to regain its power and be internally reconciled with itself. 16

In the first stage of the histary of dogma "Spirit becomes objective to itself.. It distinguishes itself from itself, issues forth from itself by means of that distinction, confronts itself as an other distinquished from itself."17 Historically this means that the first period of the history of dogma is characterized by "dogmatic assertions; doctrinal determinations, and propositions of faith, all propounded as incontestable truths."18 It is the period of definition and confession, of councils and conciliar proceeding, whereby dogma becomes an external concrete body of defined propositions of faith set forth by the phenomenal Church. Initially, this process emerges out of the religious consclousness of the subject himself. Thus,

As the subject surrenders himself to the compulsion that moves his religious consciousness, as with all his power he enters into and objectifies himself in dogma, and as he finds himself thereby internally satisfied, he can also---once dogma obtains this determinate form---come to know himself as one with 1t, for the simple reas on that the formation given to dogma is faken entirely from what the subject already possesses in himself. 19

Yet, as th1s process progresses, the subject inters increasingly into bondage to the object of religlous consciousness. "The more the subject objectifies himself in dogma in order to enter into 1t, the more he surrenders his own freedom to it."20 The process through which dogma comes to its specific formulation, has the effect of investing it with

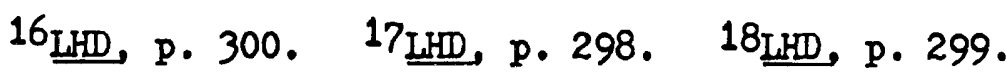

$$
\begin{aligned}
& \text { 19LH, p. 299. 20 29D. p. } 299 .
\end{aligned}
$$


an unchanging authority and therefore it ceases to move along with the reflective mind. What itself was generated out of the religious consciousness of the subject, now becomes a confining barrier, which confines theological thought to within prescribed limits. The result, according to Baur, is that:

Since dogma confronted him in all the determinations that were regarded as so essential, it became the opposing linit that he was not permitted to transgress, and by which he could only feel himself restricted the more he became aware that it was a purely arbitrary limit.21

The reflective mind becomes increasingly restive in its bondage to external object, 1.e. dogma, and begins to seek a way of mediation between objective dogma and himself. Here, the second stage has already commenced.

Historically, Baur associated the second stage in the history of dogma with the Scholastic movement of the twelfth century. At this time, he writes:

Since dogma had become so firm and objective a power in the authority of the Church. . . the subject had now to feel hinself driven to oppose dogma with all the energy of his self-consciousness, in an effart to see the extent to which he was in a position to master it.22

On this point Baur provides a glimpse of his view of the dialectic at wark in the history of dogma. Subject (thesis), in the first period, gives birth to Object (antithesis) and finally Subject, confronted by Object, finds a way of mediation with it whereby both become synthetically related. Baur identified this dialectical process with the Absolute Spirit, this his philosophy of histary is ultimately idealistic, yet it is not abstractly so because it is ultimately history itself which provides the dynamic for the dialectic and, further, provides the means 
by which Spirit comes to increasingly greater self-awareness. Subrject always has within it the aspiration to mediate object, yet that could only be accomplished if Subject is first drawn "back from the overwhelming pressure toward objectifying himself in dogma."23 This happens historically through the process described in period one of the history of dogma and through this process the dialectic receives a dynamic impetus to complete its cycle. "It was thus now legitimate to try to maintain the freedom of the subject against the predominance of dogma." 24

Scholasticism is the historical signal for stage two. Baur writes:

The major point of view under which Scholasticism must be placed is precisely the endeavor, which lies at the basis of all its major manifestations, to remove dogma from the externality and immediacy it possessed as an absolute given, resting on the bare authority of ecclesiastical faith, and to place it in subjective consciousness, to mediate it with consciousness. 25

In the Scholastic period, knowledge becomes parallel to faith although not above it. Thus, the Scholastic method of theology is primarily to demonstrate the truth inherent in Church dogma through the systematic application of reason. This is, according to Baur, "a very significant progression of Spirit, "26 but, though its dynamic is "the liberation of self-consciousness in its relation to dogma, "27 it is ultimately impotent to achieve the realization of this dynamic. Dogma ultimately retains its externality along with its autonomous authority, "simply a thing absolutely given, a solid, impenetrable authority into which the subject could never enter with the porer of his self-consciousness. . . an absolute presupposition beyond which Spirit could not move." 28 What

$$
\begin{aligned}
& \text { 23 } \underline{L D}, \text { p. } 301 \text {. 24LFD, p. 301. 25LKD, p. } 301 .
\end{aligned}
$$

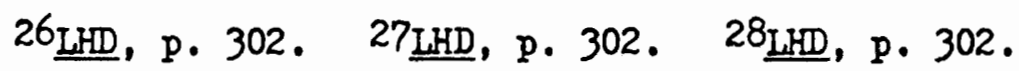


Scholasticism aspired to find is realized in the Reformation.

Historically, the Reformation represents the transition from stage two to stage three. At this point the subject does not merely stand abreast with dogma, rather, he must stand above it in judgment. "Nor," writes Baur, "should one hesitate to break completely with dogma the moment it appeared simply to be untrue and irrational to thinking reason or religious consciousness, or antithetical to religious interests."29 The principle on which the truth of dogma rests undergoes a radical change in this period from authority to the divine authority of sola scriptura. And thus,

through the Reformation the subject obtained for the first time the consciousness of his freedom, or the freed om of his self-consciousness, in relation to dogma. Dogma no longer confronted him in its externality and with the externally imposed authority of ecclesiastical doctrine; rather, it derived its significance only from the subject's knowing himself to be internally at one with divine truth, which he recognized as the essential content of dogma. 30

But, Baur notes, the cycle is still incomplete because the principle embodied in the Reformation, i.e. that the constitutive principle of the history of dogma rests with the free subject, is unable to penetrate into the general consciousness because many still "held all the mose firmly to the old principle of authority, and wanted to know nothing of a liberation of the subject from the bonds of ecclesiastical authority. "31 Thus, the final outcome of stage two is the antithesis between Catholocism and Protestantism, yet the Reformation is not simply the end of stage two, it also represents a transitional stage toward stage three. This transition is worked-out through a greater realization and application of

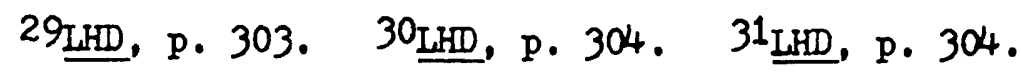


the Protestant principle. One thing that Protestantism accomplishes which works toward this realization, is the demolition of the medieval bifurcation of knowledge into two separate catagories; philosophical, and theological. He writes:

What in the Middle Ages was for so long held as the highest axiom--that there exists a double truth, one truth for theology, another for philosophy--must increasingly be discounted de facto as a false assumption. As certainly as there is only one truth, so must the antithesis between theology and philosophy increasingly be resolved and transcended. 32

This method of the use of philosophy in theology is, as has been discussed, Baur's own method. It is the only approach which will result in a synthesis of Object and Subject and the penetration of this synthesis into the general consciousness. This does not mean, for Baur, a reversal of the Protestant principle, rather, it is a more radical and truer application of 1t. Speculative method in theology is not only the logical outcome of the Reformation and the Protestant principle, it is also, according to Baur, the only hope for a new synthesis which will transcend the antithesis of Catholic and Protestant and 1ssue in a new general religious consciousness. 33 The following quote, which is Baur's concluding statement in the Lectures.... not only serves as a good summary statement with which to close this discussion of Baur's views of the history of dogma but also gives an inside view of his hope for what a speculative approach could do for a new religlous consciousness transcending

$$
32 \text { LLD, p. } 305 .
$$

33I consider Baur to be a prophet of the later ecumenical movement, although he was in his own time, almost a "volce crying in the wilderness." Baur, at this early date, anticipated many of the issues of the later ecumenical debate and in his insights on the question of doctrinal development and the nature of the Church, also anticipated some of its proposed solutions. 
Catholicism and Protestantism.

Hence only from the speculative standpoint can we perceive in the history of dogma and in the multiplicity of its contents a unity, the unity of a moving principle. For this reason, this speculative mode of reflection belongs essentially to the Protestant conception of the history of dogma--but not the Protestant conception as long as it sees in the histary of dogma only that which is singular, contingent, arbitrary, subjective, constantly changing and moving in colorful disarray. This is merely the rationalistic view and is no less one-sided--only in an opposite direction--than the Catholic. The one-sided, restricted, and limited character of these two opposing and mutually self-negating vantage points can be transcended only in the Absolute of the speculative conception. This alone can be the goal of the further development of our science. The task of my previous efforts in the field of the history of dogma was to guide our discipline increasingly toward this goal. In these lectures I would also hope to keep the same task constantly in view. 34

BAUR ON THE WRITING OF CHURCH HISTORY

Baur's consideration of the writing of Church histary was developed in connection with his ideas on the history of dogma just surveyed. His main concern overall in both the Iectures..., and the Epochs..., was to demonstrate the inadequacies of either an exclusively supernaturalistic methoiology or an exclusively rationalistic methodology in the writing of the history of dogma and Church history. The idea that one's theological viewpoint will determine the method of writing Church history is st1ll present in the Epochs...., and further, the problem of subjective consciousness coming to know objective consclousness remains the foundational problem for history. Yet, in the Epochs..., the discussion centers not so much on the relation of subject and Object, but rather on Idea and Manifestation in Church history. The key to correctly perceiving the Church historically is to understand its moving Idea as it has been manifested in history. The Church historian goes wrong when he misper34 LHD, p. 364 . 
ceives this Idea of the Church because of his own theological arientation. Characteristically, Baur begins his discussion by establishing that "history has both an objective and a subjective meaning", and therefore: "History is both what has happened objectively and the subjective knowledge of what has happened."35 Therefore, history is not directly accesible to the subject, as if he were a mere observer, or mirror, of histary wie es elgentlich gewesen 1st. "The mare precisely", he writes, "this relation is considered, the less can it simply be assumed that historical presentation is nothing but the true, adequate reflection of what objectively has happened."36 The answer to this dilemma is not, according to Baur, simply a closer examination of the facts. Such an approach will only obscure the true Idea of history. Rather what the historian must do is step back from the facts of history to view them in their wider context. This "stepping-back" from histary is accomplished through speculation. "The truth itself thus emerges in something like genuine objectivity only through the comparison of various possible standpoints, from each of which must be removed whatever has too subjective a character."37 These preliminary comments on history in general, apply as well to the histary of the Christian Church, in fact, "the nature of historical presentation becomes all the clearer when 1ts task consists in setting forth the objectively given for subjective consciousness", 38 within the Christian faith. The process whereby this setting forth of "the objectively given for subjective consciousness", is not to be accomplished through an examination of all the manifestations of the Church down through

$35_{\text {Epochs, p. } 46 .} 36$ Epochs, p. 46.
$38_{\text {Epochs, p. } 47 .}$


history and then abstracting the moving Idea and end out of which, and toward which, the Church is moving. Such an approach is too subjective and will result in reading meaning back into the history of the Church. Rather, Baur proposes:

Everything proceeds from a starting point in which the Idea that is to be realized through its entire temporal manifestation is clearly and definitely expressed; and once initiated, the development proceeds from one point to another in a continuity in which it should not be difficult to relate everything individual to the Idea that is the basis of the whole, or to determine the relation in which one thing stands to another. 39

Thus, as seen earlier, the key to the historical understanding of the Christian Church goes back to the life of its founder, Jesus. But, Baur recognized, as demonstrated through his awareness of the subjective aspect of history, that one cannot simply go back to the life of Jesus since this also is a fully historical question and thus is itself subject to the problems of historical understanding. Therefore, the real issue in the writing of Church history is not from which historical point its development is to be understood, that can only be from its beginning point. Rather, the question is; How is that beginning point to be understood?" "All the difficulties to be overcome by a historical presentation," he writes "are concentrated in the beginning itself. .40

The history of the Church, then, is to be explained not simply materially, by an outward description of its changing institutions, but rather ideologically, because the actual production of one's Church history is so determined. He writes:

Just as the church, which at the beginning was at unity with itself, split asunder and divided into the great antithesis of Protestantism and Catholicism; and just as other religious parties

39Epochs, pp. 47-48. 40 Epochs, p. 48. 
appeared in addition to the Protestant Church, as well as views that emerged within the Protestant Church itself, deviating more or less from orthodox doctrine and claiming for themselves the same title to the Protestant principle--so also all these differences embrace equally numerous and varied points of view from which the entire development of the Christian Church could be understood. 41

There are many different theological perspectives, and consequently, there are many different views on the history of the Church, such as the Catholic, Protestant, supernatural, and rationalistic views. Yet Baur believes, these approaches have "outlived their usefulness, having each evolved to a degree that oversteps the antithesis between the two." 42 This view of the obsolescence of each of these methods of considering Church history is, of course, based on Baur's own conception of the process of Church history, which understands each of these views as themselves as but the manifestation of the Spirit in history. And once again is manifested Baur's conception of man's radical historictty, and thus, his connection with the Absolute Spirit. Thus, he writes:

Taken together, all these attempts, representing the various possible points of view in particular historical presentations, form the epochs of Church histariography, in whose course the Spirit working in the depths and struggling toward the solution of its task has raised 1tself, at first gradually, to the level on which it stands in the present mode of perception. 43

It was therefore, Baur's task to examine the various points of view on Church history through a study of individual Church historians, in order to gain a historical perspective on how the original Idea of Christianity had developed in the manifestation of the Church and finally to argue for a new conception of writing Church history which would transcend these now obsolete methods.

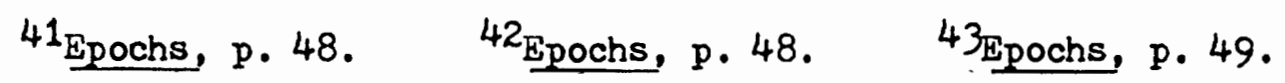


The first section of his histarlography of Church history, Baur entitles "The 0ld Catholic View of Histary: Eusebius and His Successors". Baur chooses to begin with Eusebius rather than to begin with the gospels or Acts, to avoid getting entangled with questions of New Testament criticism, even though, as already pointed out, he regards the history of Chrlstianity as beginning with the life of Jesus or the gospels. The whole period is the story of the development of the dualism which emerges out of a supernatural world-view. This development is most clearly seen in Eusebius' conception of the beginning point of Church histary. He writes:

A conception of Church history such as Eusebius, which is in principle so dogmatic that it makes the dogma of the divinity of Christ its starting point, must regard dogma in general as the substantial content of the history of Christianity. If the divine Logos has become man in order to proclaim the (saving dogma), then everything depends upon the pure and unfalsified preservation of the teaching delivered by Christ and the apostles. 44

Baur finds in this view the understanding of dogma as that which was "once delivered", as absolute divine truth, and, therefore, transhistor1cal. The effect of this view upon the writing of Church histary is that, a lately developed orthodoxy, which has emerged out of a historical process of theology, goes back and condemns the very historical figures who contributed in one way or another to the development of that arthodoxy. The result of this method is to surround dogma, as defined by the later Church councils, with an aura of absolute authority and to read this "orthodoxy" back into Church history as well as project it into the future. Each time that theological ideas are measured by this orthodoxy and judged by its confines, the myth of 1ts absoluteness becomes

$$
44 \text { Epochs, p. } 58 .
$$


stronger. Thus:

While dogma remains always the same and represents in its whole temporal manifestation only the pure apostolic tradition, the heresies form a self-composed sequence of continually changing phenomena, which in their continual reaction to dogma only serve to place the eternal unshakable truth of the latter in a vivid light. 45

This dualistic nature of Eusebius' Church history also emerges, according to Baur, in his concept of history itself which is portrayed not as an organic flowing whole, but rather as the conflict between two forces, good and evil. On this he observes:

The content of history as a whole is by no means an immanent development proceeding through various phases that mutually condition one another; it is simply a conflict of hostile powers between which no reconciliation and settlement, no fluid transition mediated by the inner nature of the subject matter itself, is possible. 46

Baur traces this dualistic view initiated by Eusebius through the course of the ancient world and very quickly through the Middle Ages which, he claims, "possessed a historical sense only insofar as it was necessary to continue the thread of the historical transmission of events. 047 This lack of historical sense, which reaches its epitomic development in the Middle Ages, is best illustrated by the false decretals of Isidore, in which "past and present were identified outright, and what belonged to the present was believed to exist for the first time in its true historical significance when it had been given the character of a tradition from the past." 48 The signal for the end of such lack of historical sense, Baur sees in Lorenzo Valla's discovery that the Donation of Constantine, which had been among the false decretals, was an utter

$$
\begin{aligned}
& \text { 45Epochs, p. } 60 . \\
& \text { 48Epochs, p. } 78 .
\end{aligned}
$$


forgery. And he states; "With this a beginning had already been made in tearing away the veil that lay upon the historical consciousness of the Middle Ages. 49

With the Reformation comes an essentially different conception of Church history which, in Baur's thinking, becomes the antithesis to the Catholic view. The Catholic view had asserted that within the true Church, there had occurred no change nor development. Therefore, it represented the true Church because it could historically trace its continuity with the early Church. The Reformation denies such a continuity on the grounds that the Catholic Church has deviated from the original Christian idea, that it, in short, has been subject to the historical process and has undergone change. On this antithesis, Baur writes:

For Catholicism, actually, there is so little sense of historical becoming that it regards what has developed temporally as something that has been from the beginning. But in Protestantism there arose for the first time a truly historical consciousness of the Church, such that it cannot accept the origin and the continuation of the Church as simply identical but must keep them separate in their essential difference. It sees in the history of the Christian Church an ever more radical alteration--and only of such a sort by which the Church has moved ever further away from what, in accord with its Idea, it ought to be .50

But, granting that such a development did indeed take place, the task still remained to demonstrate how this had proceeded historically. The task became urgent because of the antithetical claim of the Catholic absolute claim over against the Protestant absolute denial, and the historical consclousness which emerged out of this conflict now proceeded in a critical fashion. "The basic principles of the Reformation", writes Baur, "could not be maintained, nor the objections and reproaches

$$
\text { 49 Epochs, p. } 78 . \quad 50 \text { Epochs, p. } 80 .
$$


of opponants refuted, without returning to history and demonstrating from it the justification of the newly won point of view."51 And, therefore, he concludes, it "lay in the interest of the Reformation itself to bring ever more clearly into consclousness the special view of history on which it rested." 52

The great Protestant work which answered the need for such a justification of its new view of Church history was, according to Baur, found in the Magdeburg Centuries, a work conceived by reformer Matthias Flacius Illyricus (1520-1575) and designed to show the histarical process of the Catholic Church in order to remove the myth of apostolic continuity which the Church was claiming. "No other Church historical work," Baur testifled, "was to have been initiated, and carried through as far as it went, with such a clear awareness of the task that Church history in general, must perform, and in accord with so definite and methodical a plan." 53 Essentially, the Centuries conceived of Church history as an ever-increasing apostasy by the Roman Church from true Christianity. The Papacy was seen as the pernicious center of this ongoing development and further, as Antichrist itself. Therefore, the history of the Church was a critical task which consisted in "the rigorous tracking of the Anti-Christianity "from its very beginnings through its gradual growth up to the point at which it found in Protestantism the opponant by whose resistence its power was broken." 54

Even though the Protestant view of Church history up to the time of the Reformation was manifestly reflective of a higher historical

$$
\begin{array}{ll}
\text { 51 Epochs, p. } 80 . & 52_{\text {Epochs, pp. } 80-81 .} \\
\text { 53Epochs, p. } 83 . & 54 \text { Epochs, p. } 85 .
\end{array}
$$


consciousness, and represented in this consciousness an antithetical view to the Catholic position, still it was just as biased as the older view. Actually, the Protestant view, reflected in the Centuries, was just as dualistic as the Catholic view even though the symbols of light and darkness had been reversed. He writes:

Where for Catholicism the luminous aspect of history is to be found, Protestantism sees only darkness, and vice versa. But when light and darkness, truth and error, confront each other once and for all in such sharp antithesis, fundamentally it makes no difference for historical reflection whether the two parts of the antithesis are related in one manner or another. This whole way of viewing things is dualistic, and in the final analysis it has its roots in a basic conception that is purely dogmatic, either on one side or the other. 55

The Catholic view, as expressed in Eusebius, saw the story of Church history as a struggle between good and evil, in which the Church represented the good, the Devil represented the evil. Within this view, the Church is harrassed by evil, as for example seen in the martyrdom of the early Christians, but evil never overcomes the good. The Protestant view antithetically sees the evil principle in the Church itself, and the good only in the early Church before the rise of Catholicism and furither in those throughout the course of Church history who have kept themselves pure from the stain of the Roman Church. Thus, the Protestant view, which envisions the Church as invisible and existing in its perfection from the beginning, merely surviving through its struggle with the Roman Papacy and hierarchy, is not essentially different from the Catholic view which identified itself with the early Church in institutional continuity throughout the course of history. The only difference here is that Catholicism regards itself as the true Church and therefore 
exempt from the historical process while Protestantism regards Catholicism as the realm of Antichrist and can, therefore, be shown to have a history of wickedness. But the result is what is important for Baur, 1.e. that a new critical historical consciousness is injected into the writing of Church history which will later bear fruit in the dissolution of all dualisms in historical thinking.

But before the process of this dissolution could begin, another stage had to be reached in the conception of Church historiography which would demonstrate the inadequacy of both of these dualistic systems. Th1s stage was accomplished, according to Baur, through the influence of Gottfried Arnold (1666-1714), whose thought had been molded by Philip Spener, a mystic and pietist. Arnold, in his mystic and pletistic leanings, regarded the Church, or rather Christianity, as not consisting in "dogmas and symbols, but only in repentance and confession, in faith and love, and in everything that shows its practical efficacy in the inner life of man as a whole."56 Therefore, true reformation, or rather restoration, of Christianity cannot come about through polemics or be accomplished through "dogmatic formulas and definitions and upon the authority of symbols." 57 And on this point, according to Baur, Arnold holds even the great reformers such as Luther, Zwingli, and Melanchthon accountable. Armed with this conception of inner piety as the true mark of the Christian combined with the old protestant view of the Catholic Church as the habitation of evil, Arnold develops a new procedure in writing Church history which results in a new antithesis. This he develops in a work entitled Unpartheilsche Kirchen- und Ketzerhistorien

$$
\text { 56Epochs, p. } 118 . \quad 57 \text { Epochs, p. } 118 .
$$


vom Anfang des Neuen Testaments bis auf das Jahr Christi 1688, which was published in Zurich in 1699. In this work, according to Baur, Arnold deviates from the Centuriators at several significant points; first, in holding that the important element in Christianity is Inner piety and outward righteousness as opposed to dogma and creed, and second, In going beyond the Centuries in denunciation of the Catholic Church. For Arnold, the Papacy does not have "the same concrete and particular significance as he does for the Centuriators. The same guilt attributable to the Pope affects the papal clergy in principle as well. Pope and clergy belong together." 58 Baur agrees with Arnold on this point and writes approvingly:

If the Papacy itself is merely the consequence of Catholicism, the culminating point of the self-developing hierarchical system, then it is shallow and superficial to remain with the Papacy in investigating the causes of the decay of the Church, and to make the Popes responsible for everything in the Church that is to be censured. If in the Church before the Reformation everything depends so exclusively on the Papacy as the Centuriators represent 1t, then there cannot be a satisfactory explanation of how the evangelical Church, after it had freed itself from the Papacy, could nevertheless so quickly have sunk into a condition wholly similar to what had existed before. 59

Arnold finds his explanation for this phenomenon in the assertion that the important element of Christianity is piety and that the piety of Individuals is to be measured by the apostolic age and the period of the apostolic Fathers. Each one is to have his hearing, especially those called "heretics" who have stood outside the Roman Church. So strongly does Arnold feel about this approach, that he ultimately comes to regard "heretics" as the only true Christians. The process is described by Baur:

$$
\text { 58Epochs, p. } 121 . \quad 59 \text { Epochs, p. } 122 .
$$


The negative judgment, in itself justified, that the heretics could not be what the orthodox Church regards them to be, because the latter proceeds upon a false assumption, was far too quickly changed by him into the positive judgment that they must be good Christians to the same extent that the orthodox are not. . . his "unpartisan history of heretics" was made just as partisan by his deciding in advance to take the side of the heretics against the orthodox as a basic principle, and to find in them as much that is good and praiseworthy as the orthodox saw in them to condemn. 60 Ultimately, Arnold's view of history is as narrow and dualistic as the Catholic and Protestant views, and further, it is fully in line with Protestantism's hatred of the Papacy even though he carries this beyond to the clergy itself. Here, according to Baur, Arnold shows himself as "a reflection of the total impression made upon him by the present day."61 On the other hand, Arnold moves forward the emerging historical consciousness by becoming the champion of heretics. It is not that he convinces his opponants of their particular Christian virtue, nor even brings them to the point of accepting his concept of Christianity as primarily pious living. Rather, it is his questioning of "whether those who hitherto had been so quickly dismissed with an adverse judgment did not also have the right to be evaluated according to another more equitable criterion."62 The result of this questioning, according to Baur, was two-fold. First, it resulted in a "move from the abstract transcendence of the mutually exclusive antitheses to the firm ground of concrete historical truth."63 And this meant, of course, that it now became "possible to see more deeply into the natural continuity of events, so that it might be grasped through the inner course of its development, according to the various moments determining its historical existence."64

$$
\begin{array}{ll}
60 \text { Epochs, p. } 127 . & 61_{\text {Epochs, p. } 133 .} \text { 62 Epochs, p. } 135 . \\
63 \text { Epochs, p. } 135 . & 64 \text { Epochs, p. } 135 .
\end{array}
$$


Second, the polemical atomosphere with which the task of Church history had been surrounded, began to dissipate. The question of what constituted heresy was clearly a problem for Protestantism as well as Catholicism, and, thus, unless "heretics" were to become the orthodox as Arnold had argued, it had to be addressed and answered. For, "if hitherto there had been no scruples about giving free rein to polemical zeal against the Catholic Church even in the realm of history, it was now seen from Arnold how the same weapon could also be turned against one's own Church."65 "Here," Baur goes on to conclude, "Arnold!s work provided a not unfruitful lesson," which resulted in "a quieter, gentler tone, more in accord with the dignity of history. "66 What emerged out of this intellectual milieu was a transition away from the dualistic conception of history character1zed by Eusebius, the Magdeberg Centuries and Gottfried Arnold, to a conception of historical development.

The next stage in the development of Church historiography, according to Baur, happens roughly within the context of the Enlightenment and is characterized by an increasing subjectivism, yet it is considered to be a transitional stage and, therefore, still partakes of many of the elements of the previous stage. Baur now provides a clear statement as to what this stage means for the progress of Church historlography:

The further we advance into the course of the eighteenth century, the more we come upon a perlod in which the previously dominant religious and dogmatic ecclesiastical interests must yeild to a freer, more manifold and more universal aspiration. The restrictive bonds of ecclesiastical authorlty grow weaker. The more independent one becomes of them, the more does Spirit, returning into itself, not only become conscious of its freedom and autonomy,

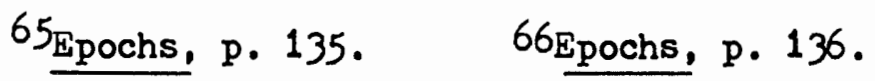


but also occupy a standpoint from which what previously was of very limited and particular interest for it now appears in a wholly different light, opening up a new area of spiritual endeavar. 67

Baur finds this ongoing process to be present in several select Individuals, Johann Lorentz von Mosheim (16/4/95-1755); Johann Salomo Semler (1725-1791); and, Christian Wilhelm Walch (1726-1784).

Mosheim's significance lies chiefly in his methodology which perceives the writing of Church history as:

the clear narration of what has happened in the society of Christians, outwardly and within, in such a fashion that from the continuity of cause and effect we can recognize divine Providance as it establishes and sustains, and thus become wiser and more pious. 68

Clearly, this indicates a move beyond the strictly dualistic consideration of the older views and seems to indicate an organic conception of the Church. But Baur finds the apparent organic concept of Mosheim's historiography to be illusory. What Mosheim's historiography amounts to 1s mere description whereby "the Church becomes a state."69 And as such, it lacks an inner dynamic which would transform it into a truly organic conception. Thus, ultimately, notwithstanding the great impetus he provides to the awareness of the historicity of the Church, Mosheim fails to develop an adequate Church historiography in Baur's estimation. Semler pressed the method of critical historiography upon the Church in a much more radical fashion than had Mosheim, and thus, he represents an even greater manifestation of the burgeoning subjectivism Baur detected in the eighteenth century. Semler had much in common with Arnold in his attack on the Roman Church, and in his emphasis on the moral aspect of Christianty as predominant. But he goes beyond Arnold,

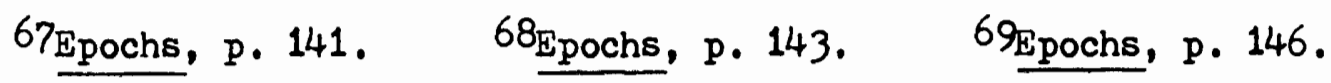


according to Baur, in his assertion that all Church history is utterly subjective, and that, therefore, elevating the early apostolic Church to a position of superiority is just as invalid as elevating the medieval Church to such emminance. In Semler, according to Baur, the outward existing structures of the Church in any age are not only of no importance to the nature of Christianity, which is moral, but they are diametrically opposed to it. Thus, Baur writes:

The main thing at which Semler takes offense in the history of the Christian church is not, as for Arnold, the steadily increasing depravity and wickedness brought on by the guilt of the rulers, but the immutability of the system dominant in the Church, which contradicts the moral nature and infinity of Christianity. 70

It is his conception of the predominantly moral nature of Christianity which leads Semler to attack the historical institutional aspects of the Church. His attacks were aimed not only at the apostolic and postapostolic periods, but even the teachings of Jesus and the New Testament as well. The result, comments Baur, was that "there was for him on the whole no objective conception of religion and Christianity," and further:

Whereas Mosheim reduced the Church in the old sense to the conception of a society analogous to the state, according to Semler it is an aggregate of individuals, who are bound to one another by no other bond than the purely formal claim of the individual existing for himself. What can the history of such individuals l.E-hare_as itsi eontent but a constant succession of changes, - whose moving principle is only the subjective tendency of individuals to react with all the power of their subjectivity against whatever may strive to impose the pressure of uniformity and unalterability on the infinite multiplicity of single individuals?71

Thus, Semler represents for Baur almost the epitome of the subjective response characterized by the Enlightenment. In the process of his critical work, which functioned as an antithesis to all dualistic

$$
\text { 70 Epochs, p. } 156 . \quad 71_{\text {Epochs, p. } 159 .}
$$


conceptions of Church history, Semler did the study of Church history a great service in providing much raw data and in furthering the conception of the Church as an historical individual.

Baur discusses Walch as a subordinate individual to Mosheim and Semler, and as a transitional figure from the subjectivism of these latter two men to the pragmatism of such Church historians as Johann Schröckh (1773-1808), Ludwig Spittler (1752-1810), Gottlieb Planck (17511833), and Heinrich Henke (1752-1809). By "pragmatism" Baur means a Church history which is rationalistic, subjectivistic and utilitarian. It is a method which utilizes history for purposes of edification or the validation of a particular idea held by the historian. Such a method, Baur detects, is already at work in the writing of Walch, especially in his treatment of heretics. Of his approach, Baur writes:

Indeed, we might think we were dealing here with a police officer or examining magistrate, rather than with a Church historian! In fact, upon examination of the entire apparatus that is constructed here--in order first to give a general personal description of the defendant and to bring him forward and interrogate $\mathrm{him}$, then to set in motion the calling of witness, to ascertain the facts, to enter the results of the investigation in the proper place, and finally to pass sentence with the necessary practical recommendations--such a procedure can be compared only with a police or judicial undertaking, in accord with the most stringent rules of a bureaucratic machine. 72

Walch's historlography and that of those who follow him later results, finally, in the "absence of all higher 1deas."73 According to this view, Baur observes, "history is only the freeplay of subjective freedom and subjective caprice," and further, "there can be no insight into the objective continuity of history, and purely subjective and Individual elements are all the more dominant."74 Walch's method is subjectivism taken to an extreme and therefore, destructive of the balance between

$$
\text { 72Epochs, p. 164. 73 Epochs, p. } 166.74 \text { Epochs, p. } 166 .
$$


subjectivity and objectivity which Baur sought. With Ghurch historiography in such a subjective corner, the only way out was a new objective view of history, "If the stream of Church historiography is not to run dry in the sands of subjectivistic particularism.75

The great period of transition or synthesis Baur located in the first decade of the nineteenth century which he referred to specifically as "the period of transition from the subjectivity of Kantian-Fichtean idealism to the objectivity of Schelling's philosophies of nature and of identity."76 This transition was but one aspect of the larger Romantic revolt and the time of the re-emergence of "higher ideas," yet it still contained some of the short-comings of the preceeding epoch. This is clearly seen, according to Baur, in the example of Johann Neander (1789-1850) who represents the first historian of the most recent epoch of Church historiography.

Neander was a Jewish convert to Christianity who had studied Plato early in the Gymnasium and later became a devoted student of Schleiermacher through the latter's On Religion: Speeches to its Cultured Despisers. Baur found Neander to be product of Romanticism especially in his treatment of history. He writes:

The most characteristic trait of Neander's historiography is here (in his monographs) revealed as a preference for the individual aspects of history, a joy in everything that allows us to look deeper within its spiritual organism, a pleasure and affection with which it traces now this and now that personality not merely in monographic presentations but also on the broad stage of general Church history.77

What prevents the meaning of histary (objectivity) from being swallowed up in this individuality, is Neander's ability "to transpose himself

$$
\text { 75Epochs, p. 167. 76 Epochs, p. } 203 . \quad 77_{\text {Epochs, p. } 210 .}
$$


with self-effacing fidelity into the full circle of that individual life, in order to understand it in itself, in its peculiar nature and circumstance."78 It is this transposition which guards against over-subjectivism in historiography and allows history to speak for itself. Thus, the task of the historian is to familiarize, indeed immerse, himself in the consciousness of the age he studies and then examine individuals in the light of such consciousness. Only then can history obtain "that objectivity which according to its very conception it must have."79

Baur approves of Neander's methodology because he recognizes that it provides for diversity while still maintaining "a common bond of unity, 80 To a great extent, Baur believes, Neander has managed to preserve the objectivity of history. But he accuses Neander of not going far enough on two related points. First, Baur sees Neander's 1deas as providing too much freed om to historical individuals and, thus, endangering the overriding unity of history. His understanding of a consciousness in each age, which is ultimately derived from Schleiermacher, does not provide a true unity at all but only a psychological or abstract unity which is essentially subjective. Second, Baur finds in Neander a lack of a "principle of movement and progressive development." 81 In its place he finds a lurking dualism between Christianity, on the one hand, which Neander considers as "an absolutely supernatural miracle," 82 and human nature on the other. Baur challanges this view:

If Christianity is so different in principle from human nature that its origin cannot even be explained from the depths of human nature, then Christianity and human nature are two essentially

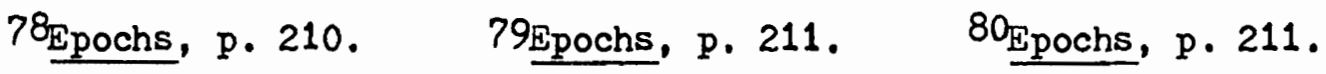

$$
\begin{aligned}
& \text { 81 Epochs, p. } 215 . \quad \text { 82Epochs, p. } 213 .
\end{aligned}
$$


different principles, opposites, which as such are related only externally. They work on each other externally, jostle each other, affect each other this way or that, but can never become internally one with each other. 83

Such a conception of history could not provide an adequate dynamic to uphold an organic view of history, according to Baur, for "where there is no unity of principle, but only a duality of principles, there can be no immanent development, no progression. " 84 Yet the dualism of Neander does not call for demolition, as the old Catholic or Protestant views do, because:

Where there are spiritual tendencies, there must also in principle be a unity; and where could this unity be found but in the common religious Spirit of humanity? That Spirit alone is the true, living and concrete mediation between a Christianity that is not absolutely supernatural but natural as well, and a human nature embodied in the multiplicity of individuals. 85

Thus, Neander is an extremely impartant step toward the objectivization of Church history in his postulation of spiritial tendencies, but he fails to be objective enough to suit Baur. Neander's ultimate subjectivity derives from Schleiermacher who taught him to think in terms of immediate consciousness, and, therefore, writes Baur, notwithstanding his emphasis on the individuality of history, "all these forms are repeatedly dissolved and carried back to the subjective element of feeling which alone is the true, inner ground of the life of history." 86 This was essentially the state of Church historiography when Baur wrote and, therefore, the immediate context of his proposed solution, which he put in terms of Idea and Manifestation.

Baur noted in the concluding section of the Epochs. . ., that 83 Epochs, p. $214 . \quad 84$ Epochs, pp. 221-222. 85Epochs, p. 222.
86 Epochs, p. 227. 
historiographic method was making great strides in his day, both in terms of the appropriation of data, and the development of a greater historical consciousness. This advance was especially evident to him in the acknowledgment "that the historian can be equal to his task only in so far as he transposes himself into the objective reality of the subject matter," and, thus, become "simply a mirror for the perception of historical phenomena in their true and real form." 87 Yet, among Church historians, Baur detected a lack which "prevents them from achieving greater. perfection."88 The old dualistic conception of Church history was dying, as the Church's historicity was Increasing being uncovered, but as Important as this development was for Church historiography, it had not led to an adequate understanding of Church history. Rather, Church histary had become essentially pragmatic and subjective, Baur conceived his task to be the transcending of this "pragmatic mode of treatment, " 89 toward a balanced objective and subjective mode of treatment, and he discovered the key to this new understanding in 1dealistic philosophy. The basic problem, according to Baur, could be located in "a wrong relation of the Idea to the manifestations in which its historical development is to be presented." 90 What happens in current Church historiography, he wrote, is that:

The Idea still hovers indefinitely and at a great distance over the manifestations to which it must be related. It is not yet strong and vital enough to penetrate and vivify the historical material, as the soul animates the body, or to become, through such an organic unity, the moving principle of the entire series of manifestations in which the history of the Christian Church takes its course. 91

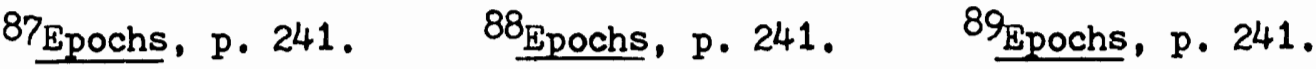

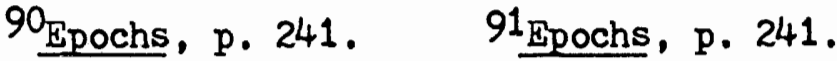


This charge that no acceptable dynamic had been suggested to account for the organic life and growth of history was Baur's major criticism of Mosheim, Semler and those who followed. Indeed, the work of these historians marked an advance in Church historiography in that they stepped beyond the dualism of ancient and medieval Church historiography wherein Church history was considered static, to a new historical consciousness which understood the Church as fully involved in the flow and flux of history. Yet, according to Baur, although their treatments of Church history were more aware of the historicity of the Church, they still remained somewhat static because of their failure to show why there should be any historical progression and change at all. In short, they showed that the Church had a history but they had not shown why it had a history. The major problem of Baur's life, was to discover a speculative philosophy which would provide such a dynamic for historical understanding, a problem which he evidently conceived early in his career when he wrote in his first major work Symbolik und Mythologie...: "Ohne Philosophie bleibt mir die Geschichte ewig tot und stumm."92 Baur had found such a philosophy in Hegelian idealism and thus wrote twenty-five years later in the Epochs. ..:

If it is right to speak of an Idea of the church, then that Idea, like any other, must possess within itself the living impulse to go out from itself and to become actualized in a series of manlfestations that can only be regarded as various aspects of the relation that exists generally between the Idea and its manifestation. 93

92Quoted in A. H1lgenfeld, "Ferdinand Christian Baur nach seiner wissenschaftlichen Entwickelung und Bedeutung", Zeitschrift für wissenschaftliche Theologie, XXXVI: $1: 2,(1893)$, p. 229.

93 Epochs, p. 242. 
The true understanding of Church history, for Baur, was to be found in the relationship between Idea and manifestation and this relationship, he illustrated by the two great epochs of Church history, the pre-and post-Reformation periods. In the pre-Reformation period, the Idea of the Church comes to be closely identified with the external historical Church, thus, Idea and manifestation become closely identified and come together "In an inseparable unity." The Reformation was the point of a great shift in which the Church now sought to "separate Idea and manifestation to the full extent of their distinction."95 Now, writes Baur:

The Idea of the Church is torn away from its manifestation as the visible Church; it is in itself the driving and moving principle of progression away from one form of consciousness, in which as an untrue existence it can no longer remain, to another form, in which it is freely related to the manifestation in the same proportion that it stands above it. 96

But this is mere description of what has happened to the Church historically and too external for his purposes. Baur wanted to go behind the manifestation and here the "question surely arises as to what content the Idea of the Church intends to transpose from itself and to realize in the visible Church, ar, since it can realize nothing other than itself, what it is essentially." 97

To begin with, for Baur, "the Church is the real form in which Christianity is made manifest." 98 Therefore, the real question concerns the Idea of Christianity itself. On this, Baur states:

Christianity can be essentially nothing other than that which the Christian consciousness of all times, in whatever form it may have occurred, has perceived in the person of Christ: the unity and union of God and man. . . It has its absolute conception

$$
\begin{aligned}
& \text { 94 Epochs, p. } 243.95 \text { Epochs, p. } 243.96 \text { Epochs p. } 248 . \\
& \text { 97Epochs, p. } 244.98 \text { Epochs, p. } 244 .
\end{aligned}
$$


and expression in the unity and union of God and man, as that unity is perceived in the person of Christ, and in this perception becomes a fact of Christian consciousness.99

The whole story of Church history was summed up and explicated for Baur In the Idea of reconclilation, which first came to consciousness in Jesus Christ. All the external manifestations of the Church, represented by dogma (the theological aspect) and polity (the institutional aspect), 100 were considered to be developments whereby "the Church proceeded to realize the Idea of that unity in such fashion that Christian consciousness could find in it the adequate expression of its Idea."101

With this Idea of Christianity as a basis for the consideration of Church history, then, Baur hoped to go beyond the impasse he saw in the Catholic/Protestant antithesis. Neither one possesses absolutely the Idea of the Church, and neither one is immune from historical flux. Rather, they are like stages passed through on the way toward a higher development. Thus, for example, he writes that Catholicism is justified In its past (even though now obsolete) "since only by means of it could the Idea of the Church progress to a new form of realization, and Christian consciousness to a higher level of development."102 The incongruity of Catholicism's ultimate identification of Idea and manifestation as synonymous, first, in dogma, and then in polity, explains the Protestant Reformation as a reaction to such identification. The opposition which began with polity or, more specifically, the Papacy, spread

99 Epochs, p. 244 .

100 Baur's representation here of dogma and polity as but two equal manifestations of the Idea of Christianity, represents a shift away from his earlier conception of dogma as the inner aspect of Christianity in contrast to polity, which he conceived of as the outer aspect. Cf. LHD, p. 262 . 101 Epochs, p. 244. 102 Epochs, p.-250. 
to the other element of the manifest Church, dogma. Thus, he observes:

just as the realization of the Idea of the Church in Catholicism progressed from dogma to hierarchy and its completion in the Papacy, so the dissolution of the unity that Catholicism perceived in the visible Church proceeded from the denial of the Papacy to the denial of dogma. What was denied in dogma concerned first of all only the elimination of elements introduced into dogma by the hierarchy and the principle of tradition on which it rested. But once ignited, the process of dissolution had here as well to pursue its further course, and it did so in the same fashion as with the Papacy.103

The realization of this dissolution of the dogmatic principle did not come about until the eighteenth century, yet it was fully contained as a presupposition within Protestantism from the beginning. With this realization comes the final freed om of the subject and the triumph of criticism. But Protestantism is not the end of this development for it too evidences its historicity. In the end, he writes: "What alone must remain forever incomprehensible is that which could in advance make the claim to stand in the midst of history outside of all historical continuity."104 The life of its founder provides the paradigmatic model for the Church's own Iife. It can never, in any form or historical age, achieve the Ideal in a manifest way. Rather, it approximates the Ideal as it, as closely as possible, expresses and structures itself so that the Idea of Christianity, i.e. reconciliation, finds its most adequate expression.

Therefore, for Baur, Christianity partakes of both idea and manifestation; it is both a universal Idea and an historical manifestation. Because Christianity is historical (and its history begins with its founder), then it can to a great extent be examined and known historically. As already indicated, Baur never held back from applying a 103 Epochs, p. $251 . \quad 104$ Epochs, p. 253. 
critical method to Church history even to Jesus and the canonical books. This he could do without fear because of his view of the historicity of Christianity. Yet Baur asserted that Christianity was not merely a historical phenomenon as Strauss did in his Leben Jesu. Baur believed Christianity to be a revelation given from God even though he meant revelation in the special sense of a consciousness first provided and exhibited to man in Jesus. Thus, Christianity was not only to be understood historically and critically, but also theologically. The true understanding of its nature was to be found in its original Idea of reconciliation. Baur was opposed to all dualisms and never conceived of Christianity as being split into categories such as Geschichte and Historie. In his understanding, Idea and manifestation, while not synonymous, were nevertheless inseparable, functioning in a dialectical relationship. This relationship was the dynamic of Baur's Church history that he found lacking in others. It was this conception of Idea and manifestation which beought together in him the critical judgment of the historian and the universal awareness of the theologian. 
CHAPTER V

\section{CONCLUSION AND EVALUATION}

In this paper, Bawr has been interpreted primarily as a romantic theologian. His romanticism is most clearly seen in his concern for a synthetic understanding of Subject and Object, or, more specifically, Idea and manifestation. In his view, the Subject does not autonomously stand apart from nature and history, and directly perceive them. Rather, Baur held that the Subject himself is involved in an objective process of development proceeding in the world. This position is not so much a contradiction of supernaturalism and rationalism as it is a redress of the balance between the two. For him, it was not a question of the priority of either Object or Subject, but rather of the necessity of both Object and Subject together. Baur draws on both the objectivism of supernaturalism and the subjectivism of rationalism, and, therefore, as his former student Hilgenfeld says, he is "noch ein Sohn des 18. Jahrhunderts, des Jahrhunderts der Aufklärung."1 Yet, he transcends both of these views in his conception of a higher synthesis, and it is precisely at this point, that Baur is to be understood as a romantic.

But, Baur does not quite fit the category of "romantic", because while many of the romantics ultimately failed to maintain the balance

1D. Adolph Hilgenfeld, "Ferdinand Christian Baur nach seiner wissenschaftliche Entwicklung und Bedeutung", Zeitschrift für wissenschaftliche Theologie XXXVI: 1: 2, (1893), p. 223. 
between the infinite and finfte, he managed to hold them together, at least to his own satisfaction, successfully resisting the tendency to subsume the finite under the infinite. In all his works, he consistently demonstrated his resolve to take the events of history seriously and not to understand them as merely the insignificant expressions of the abiding Spirit. At this point, Baur appears as a representative figure of the growing historicist movement, in both his emphasis upon the growth of history and his attention to historical facts. His own personal study of histary and classics, combined with his study of B. G. Niebuhr, no doubt instilled in him the scientific attitude towards historical facts. Thus, Baur appears as a unique historical figure who cannot be fully identified with pietism (supernaturalism), rationalism, romanticism, or historlcism: he drew on all of these sources, yet he cannot simply be reduced down to them. Rather, these influences came together in Baur to produce a view of Christianity which was at once both fully historical and ideal.

Baur's mediating place between romantic idealism and positivistic historlography drew two different accusations against his work. On the one hand, are nineteenth century historicists, most notably Ernst Troeltsch, who accused Baur of sacrificing the particulars of history to the schemes of speculative philosophy. Troeltsch wrote, for example:

Baurs Werk ründet auf die besondere Fassung des Entwicklungsgedankens in der Hegelschen Dialektik. Er stellt die Geschichte des Christentums als die Selbstentfaltung und Selbstbewegung der christlichen Idee und die christliche Idee selbst als den Hôhepunkt der in der Universal- und Religionsgeschichte sich entfaltenden religiös-metaphysischen Idee überhaupt dar. Die Folge davon 1st, daß die selbständige Glaubenslehre ganz überflüssig, daß die ganze Kraft und Fülle des Christentums gerade in seiner Geschichte sichtbar und wirksam, daß die Kirchengeschichte die Menschwerdung Gottes und die Explikation Christi, alle Theologie 
und Christologie also überflüssig wird. ${ }^{2}$

From this point of view, therefore, Baur is too idealistic and fails to consider Christianity in its full historical variety. 3 on the other hand, are dialectical theologians, most notably Rudolph Bultmann, who have accused Baur of placing too much importance on historical details. The point of this criticism is not so much that Baur has erred in his conception of the relation between truth and history, but rather, in the words of Bultmann, "by reducing faith's self-understanding to a consciousness which arises in historical development out of man himself so that in him the mind comes to consciousness of itself, he eliminates the kerygma." 4 Thus, man is no longer confronted with the kerygma; rather, it dawns upon him gradually through historical consciousness. These two criticisms are among the most serious which have been leveled at Baur and, therefore, must be examined more carefully.

Troeltsch' charge that Raur is too speculative in his treatment of history is really not consistent with the evidence. In the first place, on many different occasions, Baur denied that he ever sacrificed the facts

2Quoted by Klaus Scholder In "Ferdinand Christian Baur als Histor1ker" Evangelische Theologie, XXXI; 10 (1961), p. 435.

3This particular criticism of Baur's historiography has been rehearsed more recently by Christoph Senft, a former student of Rudolph Bultmann. He claims, "der Hegelsche Geschichtsbegriff, den er adoptiert hat, verhindert letztlich doch die erstrebte wahrhaft objektive Erkenntnis," and that, therefore, for Baur, history is only "ein bloBes Attribut des Selbstbewußtseins." (Christoph Senft, Wahrhaftigkeit und Wahrheit: Die Theologie des 19. Jahrhunderts zwischen Orthodoxie und Aufklarung (Tübingen: J. C. B. Mohr, 1956), p. 76 .

${ }^{4}$ Rudolf Bultmann, Theology of the New Testament Vol. II, trans. by Kendrick Grobel (New York: Charles Scribner's Sons, 1955), p. 244. 
of history to the confines of a system. 5 on the contrary, he maintained that any historical study begins with the facts and must stick closely to them. In his Epochs..., for example, he wrote: "There is no historical presentation that must not first be critically tested in order to determine the relation in which its author stands to the pure objectivity of histarical truth."6 Yet, after the critical testing has been accomplished, there is still the question of what it all means. Therefore, he concludes, "history itself, as the essence of what has happened, remains something so infinitely large that its contents can never be exhausted by historical knowledge."? In these statements, Baur's method is shown to be just the opposite of what Troeltsch claimed it to be. It is not "gründet auf die besondere Fassung des Entwicklungsgedankens in der Hegelschen Dialektik", but rather, based upon Baur's own historical research. A speculative method of approach in understanding the facts, after they have been collected, is valid and indeed useful if it does not take priority over the facts themselves. But the facts must inform one's speculation and, therefore, Baur asks rhetorically, "On the whole, can history have a higher task than the ever deeper investigation of the historical continuity linking all phenomena that lie before it as given objects?"8 Thus, Troeltsch's charge that Baur's idealism makes Dogma, the history of Christianity, the incarnation and the revelation in

5 See, for example, F. C. Baur, Ausgewählte Werke in Einzelausgaben Band I, pp. 267-268; and also Hodgson's comments in The Formation of Historical Theology, p. 4.

6F. C. Baur, Epochs..., p. 46.

7F. C. Baur, Epochs. ... p. 46.

8F. C. Baur, Epochs..., p. 253. 
Christ "überflüssig, is not true. On the contrary, as has been shown in the discussion of his concept of revelation, Baur's system actually depends and, indeed, insists upon the historicity of these things. Historical events, carefully examined, provide the clues to the truth of history, and are, therefore, of primary importance.

In the second place, Baur's scholarly production supports his own testimony that historical facts are of primary importance. Here the Die Christusparte1.... is especially illustrative. In this work, which precedes Baur's contact with Hegel by about two years, he began with a careful consideration of I Cor. 1:12 in the light of its literary and historical context and from this, asserted that the verse provided evidence of a great struggle going on in the Corinthian congregation between a Peterine party which was essentially Judaistic and a Pauline party which was made up of Hellenistically oriented Christians. Later, on the basis of this observation, Baur went on to apply this insight to the other Pauline epistles, such as Galatians, where he believed he discerned the same struggle to be present, and also to the gospels. Yet in all of his monographs, even those coming after his acquaintance with Hegel, Baur sought to base his conclusions soundly upon his prior historical research. His aim was the bigger picture, but he never reached for it prematurely, as Scholder notes:

Zweiundzwanzig Jahre also liegen zwischen dem ersten Aufsatz und der Kirchengeschichte. Und an jeder einzelnen historischen Arbeit, die im Laufe dieser zweiundzwanzig Jahre entstand, kann man nachweisen, daß Baur zu keiner Zeit den großen Entwurf der frühen Kirchengeschichte aus den Augen verloren, vielmehr in ebenso unermüdicher wie unbestechlicher. Arbeit an den Texten diesen Entwurf Zug um Zug ausgebaut, ergänzt, überprüft und abgesichert hat. 9

9Kaus Scholder, "Ferdinand Christian Baur al Historiker", p. 44 ? 
As the above quote suggests, Baur's consistent attention to historical facts in all his works, in addition to the fact that he came to the writing of his Church history (the big picture) only late in his life, only after he had laid a vast foundation of sound scholarship and erudition, argues against the contention that Baur ignored history in favor of philosophy. Historical particulars were integral to Baur's understanding of revelation; indeed its sine qua non.

Bultmann's accusation that Baur gives too much importance to the historical process and consequently eliminates the necessity for the kerygma is incorrect because it is based upon a misunderstanding of Baur's concept of revelation. The misunderstanding involves this controversial passage from Baur's Lehrbuch der christlichen Dogmengeschichte (1847):

What history is generally--as the eternally clear mirror in which spirit perceives itself, views its own image, in order to be what it is in itself also for itself, for its own consciousness, and to know itself as the moving power of historical becoming--is concentrated in an all the more intensive significance in the restricted field of history of dogma. 10

The controversial words here, are 'history' and 'spirit'. Does he mean here by 'history' the study of history or the process of history? And, further, does he mean here by 'spirit' the eternal Spirit or merely the human spirit? Those who read Baur strictly as a romantic idealist tend to understand him as meaning by these terms, the self-realization of the eternal Spirit in the historical process. 11 Thus, man arrives at his

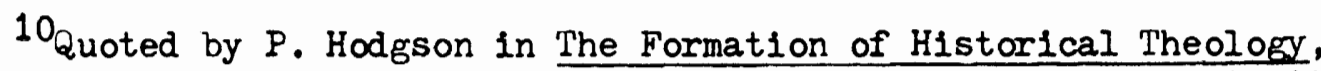
p. 182. I am indebted to Hodgson for his observation of the ambiguity between the words 'history' and 'spirit' in this most difficult passage.

$11_{\text {Barth has interpreted him this way. See his Protestant Theology }}$ in the Nineteenth Century, p. 507. 
awareness of reconciliation by virtue of his involvement in the eternal Spirit and the historical process. According to this view, Baur has no real concept of revelation, and historic events are only temporal, ephemeral manifestations of the Eternal Spirit. But this goes contrary to what has already been shown regarding Baur's concept of revelation and history.

Another way of understanding Baur in the passage from the Lehrbuch, is to interpret 'spirit' not as the Eternal Spirit, but as the human spirit. Thus, the human spirit recognizes the truth as it unfolds "in the totality of the historical course of development."12 This is Bultmann's understanding of the passage and consequently, he writes:

Since, therefore, historical reflection is the way to grasp the truth, then historical investigation of the history of Christianity--primarily of its origin and hence of the New lestament--is the way to grasp the truth of Christian faith, a truth which for Baur is unquestionably no other than the truth of the human mind in general. Hence New Testament theology must understand the interpreting of the New Testament to be the unfolding of Christian consciousness, which is itself understood as a decisive stage in the process by which the human mind comes to itself. 13

Thus, according to Bultmann, Baur holds that history as a process is an "eternally clear mirror" in which the human spirit "perceives itself, views its own image, in order to be what it is in itself also for itself, for its own consciousness."14 Based upon this interpretation, Bultmann then voices his objection that Baur's view makes faith only "a consciousness which arises in historical development out of man himself."15 In

$$
\begin{aligned}
& 12_{R} \text {. Bultmann, Theology..., Vol. II, p. } 244 . \\
& 13_{R} \text {. Bultmann, Theology..., Vol. II, p. } 244 . \\
& 14_{R} \text {. Bultmann, Theology..., Vol. II, p. } 245 . \\
& 15_{R} \text {. Bultmann, Theology..., Vol. II, p. } 245 .
\end{aligned}
$$


consideration of this interpretation, Hodgson has observed that Bultmann's critique is based on the assumption that by 'history', Baur meant 'historical process' rather than the study of history. Although, given this assumption, Bultmann's critique is valid, Hodgson questions the validity of the initial assumption. Rather, on the basis of the context and a strikingly similar passage from another work, Hodgson maintains that by 'history' Baur means the study of history and concludes:

The past is by no means merely a moment in the present dialectic of human thought, as Senft claims. The study of the past is rather the "inexhaustible source" from which the present obtains its moral and spiritual foundations. 16

Whether or not, Barth; Bultmann, or Hodgson understands Baur correctly on this point, the real problem underlying their debate, is the larger question of how Baur finds a place for both God and man in his system. He is clearly intention having them both in a free relationship where the freedom of both is maintained, 1.e. neither God becoming a projection of man himself nor man becoming an idea in the mind of God. This is seen in his insistence, that the finite is not to be sacrificed to, or subsumed in the Infinite, and vice versa. Yet, in spite of this insistence, he never clearly explains their presumed connection or relation, and this is Baur's greatest weakness, one he shared with other idealists. The ambiguity is clearly seen in his Christology where Baur draws back from identifying the historical Jesus as divine. By conceding to Jesus only the highest consciousness of reconciliation, albeit not in absolute consclousness, he hopes to preserve both God's transcendence and the ultimate meaning in historical events. He accomplishes this

16P. Hodgs on, The Formation...., p. 184. 
philosophically by combining, as Hodgson notes, an historicism with a panentheistic monism ${ }^{17}$, but he still leaves the question of how Spirit impinges upon historical events without becoming entangled in them.

Baur's task is complicated by his profession of the Christian faith. He must preserve the importance of the historical Jesus and the Gospel, and, to do so he draws on philosophy to provide a model. But the question that needs to be asked is: Does Baur really preserve these two things? From the standpoint of orthodoxy, the answer is no. Orthodoxy has always held and maintained that the historical Jesus was very God and very man in one person and, further, that his death was a substitutionary or representative sacrifice on behalf of man, through which reconciliation between God and man has come. Baur deviates from the orthodox position in seeing Jesus as only relatively divine; in holding that his death has only a psychological significance for the believer; and, finally, that reconciliation comes via the initial consciousness of Christ. The historicizing of Jesus has far-reaching consequences for theology although they were unrealized by Baur. Partly as a consequence of Bawr's own work, Christianity itself, or more specifically the Gospel, became relativized in the work of later theologians. 18 Still, in spite of his unorthodox Christology, Baur's work is important for today, in that,

17Hodgson, The Formation.... p. 269.

18 Here, the paradigmatic example is Ernst Troeltsch (1865-1923), who, from a more positivistic position: than Baur, - saught: to harmonize the historicity of Christianity with the Gospel proclamation of its absoluteness. In The Absoluteness of Christianity and the History of Religions, he sought to establish the normativeness of Christianity among all religions, while arguing for 1ts superiority over them. In his later work, Troeltsch evidenced an even greater conviction that Christianity is radically historical. On this development, see E. Troeltsch, Protestantism and Progress Boston: Beacon Press, 1958. 
while Protestant theology has demonstrated a marked tendency to separate faith and history, or, at best, to equivocate on the meaning of history, Baur calls theology back to the problem of history. 19 On this, Hodgson writes:

Baur is correct in suggesting that an historical event or an historical process is one which is in principle knowable--not necessarily actually known--through historical understanding, i.e., by a discipline which is at once critical and imaginative. Although it is quite probable that an historical event can also be known in non-historical ways, e.g., through faith, an event from which historical understanding is totally excluded in principle is not an historical event. Therefore, the Protestant tendency to say that God reveals himself in history, but not in the sort of history knowable by historical study, implies an incipient docetism.20

The problem of faith and history is not solved for theology by Baur, but the issues and terms are clearly laid out by him. The question of faith and history has never been so important as it is today, and the rediscovery of Baur's work has contributed to its current importance. Here, Baur has done theological posterity a great service.

The same can be said, especially of his work in the field of Church history where Baur's awareness of, and emphasis on, the historicity of all phenomena produced a more realistic concept of Church history. From a methodological standpoint, Baur's work represents not only a significant advance in the writing of Church history, but also the foundation for the scientific study of Ecclesiastical history. His constant attention to the facts of history helped him to escape from the earlier treatment of

${ }^{19}$ See Heinz Liebing "Historical-Critical Theology", especially p. 69, where he writes, for example: "we cannot avoid the question which Baur pressed upon the theology of his time, when he taught it to understand that history was its own deepest problem."

20p. Hodgson, The Formation..., p. 273. 
Church history as the servant of polemics, apologetics, or edification. For him, Christianity is and remains an historically given religion (eine geschichtlich gegebene Religion), open and accessible to the consideration of the historian. Concerning the results of his own researches, he would have been the first to admit the incorrectness of his theory on the rise of the early Church in its historical particulars. Yet, as earlier indicated, this does no damage to his theory in its essence. Baur's assertion that the early Church was a conglomerate of heterogenous factors, involving various theological points of view, in contradiction to the earlier view of a homogenous early Church, has never been more established than it is today. The only difference is, that the modern understanding of the heterogenous character of the early Church is more complex than Baur conceived 1t. Thus, Baur stands as one of the most important figures in Church historiography. On his significance as a historian, Scholder concludes:

Die neue Grundlegung die Baur hier der ganzen kirchengeschichtlichen Arbeit gibt, ist für diese Disziplin bis heute unverändert gültig, wenn wir allerdings auch in der Beurteilung inrer Ergebnisse vorsichtiger geworden sind. 21

But Baur's work goes beyond being significant only as a method of Church historiography. In his insistence that history cannot be fully understood apart from philosophy or at least speculation, he established implicitly that Church history could not be only a historiographic task, but a theological task as well. For Baur, Christianity was not only a historical (geschichtilch) religion, it was also a given (gegebene) religion. Therefore, a mere historical understanding of it was not only adequate, but, really, impossible. For him, historiography and theology, $21 \mathrm{~K}$. Scholder, "Ferdinand Christian Baur. . .", p. 449. 
like history and faith, must always remain together. For example, in the concluding section of the Epochs..., he wrote:

The singular and the manifold are two equally essential basic forms of Church life; but we must also think of the two in an immanent relation to each other such that the singular opens itself to the manifold and the manifold is comprised of the singular. In proportion as the historian must, on the one hand, become absorbed as deeply as possible in the particular, individual, and concrete aspects of historical phenomena, in order to attain the complete reality of historical life, so on the other hand he must also raise himself to the heights of the universal Idea, in order to grasp the particular from the universal and to see in it only the particularity of the universal. The task of histariography is completed only in the union of these two mutually complementary methods, which make up the two aspects of the same process--moving from the particular to the universal and from the universal to the particular.22

It is in his maintenance of both histariography and theology within his Church history, that Baur's real significance lies. His insistence that the form of the Church never absolutely embodies its idea is adequate to comprehend the Church's historicity, while his assertion that history is dead without some speculative system makes room for a theological consideration of the Church's absolute idea.

The awareness of the Church's historicity, which began with Baur, has emerged in our own day as a movement for change and reform among the major denominations. Ecclesiology has become self-conscious and this self-consciousness stems from the very concept of the Church which Baur helped to establish; that the Church, as a worldly, social structure, partakes of temporality, even as other social institutions, such as political structures or economic systems, do. It involves a shift in eccleslological thinking from the categories of nature to the categories of history. Within the categories of nature, the Church was conceived

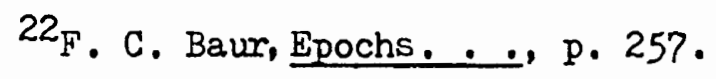


as "quod semper, quod ubique, quod ab ominibus creditum est." This view was dependent upon the dualism of the old supernaturalism. But such an ecclesiological model, as Baur clearly saw in his own day, is inadequate for the modern world, since the world is no longer conceived in static, but rather, dynamic, catagories. A sample of the new ecclesiological thought is provided by Colin Williams, who writes:

There is need to think of the church-world relation in much more humble and much more dynamic and secular fashion than we have been accustomed to in the past. It must be more humble in the sense that we must learn to stop thinking that the role of the church is to draw the world into the order of the church. We must cease thinking of the ultimate salvation of the world as the process by which Christ's Lordship over the body (Col. $1: 18$, Christ as head of the church) is expanded until at last it draws the whole world into its realm (Col. 2:10, Christ as head of the creation). Christ in his movement toward the fulfillment of his Lordship in the creation uses the community of those who already know him as Lord. The church is the servant of his struggle to bring this new and free life to expression in the communities of the world. But the goal is the new life of the creation. The church is to be seen as an instrument that Christ uses for realizing the goal. 23

The results of this new conception of the Church have been profound for its practical ministry in the world, but to rehearse them here is beyond the scope of this paper. More relevant here, is the impact of this new conception on the writing of Church history.

After Baur's death, his unique conception of the process of history

23colin Williams, The Church Vol. IV. of New Direction in Theology Today (Philadelphia; The Westminster Press, 1968), pp. 22-23. The concept of the Church here expressed by Williams is not an isolated view but representative of a virtual revolution in ecclesiological thinking. The foundation of this new ecclesiology were laid down in the 1960's, but the implications for the practical ministry are still proceeding vigorously. On this, see Donald Bloesch, The Reform of the Church Grand Rapids, Mich.: William B. Eerdmans Publishing Company, 1970; and Howard A. Snyder, The Problem of Wineskins: Church Structure in a Technological Age, Downers Grove, IIl.: InterVarsity Press, 1975. 
itself as having meaning was lost, either to a reactionary conservatism which sought to reaffirm the dualistic concept of church/world, or to positivistic historiography which lead to a complete relativism. Those who followed Baur's method at all, usually applied his sense of historicity to the Church while tending to neglect its theological significance. Consequently, as Bultmann observes: "Investigation fell victim to a historicism which conceived early Christianity and with it the New Testament as a phenomenon within the closed continuum of world history Iinked together by cause and effect."24 The Neo-orthodox movement was a reaction against this reduction, and an attempt to recapture the transcendent aspect within Christianity, but it failed, on the other hand, to adequately account for the historicity of the Church. Thus, both nineteenth century liberalism, which tended to over-emphasize the historical aspect of Christianity; and Neo-orthodoxy, which tended to over-emphasize the ideal aspect of Christianity, falled to maintain the balance which Baur had . sought.

The increasing realization of the worldly aspect of the institutional Church by theologians which can be termed simply ecclesiastical selfconsciousness, has resulted in a new redress of the balance between historiography and theology in the writing of Church history. Two Church historlans exemplify this development: Jaroslav Pelikan, a Lutheran pastor and teacher, who has been actively involved in the ecumenical movement; and Jan Walgrave, a Dominican, and speciallst on the problem of doctrinal development and the life and thought of Cardinal John Henry Newman.

$24 \mathrm{R}$. Bultmann, Theology of the New Testament, vol. II, p. 245. 
Pelikan, like Baur, is intent upon preserving the unity of both theology and history. He wishes to understand the Church historically, but not merely historically. In his own terms there must be a balance between tradition (the abiding), and history (the transitory), if the Church is to be truly understood. He writes:

Tradition without history has homogenized all the stages of development into one statically defined truth; histary without tradition has produced a historicism that relativized the development of Christian doctrine in such a way as to make the distinction between authentic growth and cancerous aberration seem completely arbitraxy. . .. The history of Christian doctrine is the most effective means available of exposing the artificial theories of continuity that have often assumed normative status in the churches, and at the same time it is an avenue into the authentic continuity of Christian believing, teaching, and confessing. Tradition is the living faith of the dead; traditionalism is the dead faith of the living. 25

Although Pelikan diverges from Baur on such points as the proper subject matter of Church history, and the identification of the abiding element within Christianity (Pelikan-tradition/Baur-idea), they are still in agreement over the necessity of a balance in Church history, between theology and history. Pelikan, like Baur, places his history of dogma upon a theological presupposition which he states as, "the variety of theologies and the unity of the gospel--the unity as well as the variety, and the unity within the variety. . Credo unam sanctam catholicam et apostolicam ecclesiam."26 Thus, Pelikan, in agreement with Baur, sees the task of Church history as both theological and historical, but Pelikan's approach is less idealistic than Baur's.

25Jaroslav Pelikan, The Christian Tradition: A History of the Development of Doctrine Vol. I (Chicago: The University of Chicago Press, 1971), p. 9.

26J. Pelikan, The Christian Tradition. .., p. 10. 
In some respects, Walgrave is even closer to Baur's thinking than Pelikan by virtue of his more extreme idealism, even though Walgrave does not carry his idealism as far as Baur. He is intent on understanding the Ohurch, both theologically, as a divine idea; and historically, as a human institution. He writes:

As historicity belongs to the very nature of the forms (human forms), the temporal Church is not exempt from the necessary laws of all historical existence. On the level of cultural incarnation no distinction can be made between a part that is supra-historical and beyond change and another part that is historical and subject to change. The ontological reality of the Church is simply suprahistorical and therefore always the same, but its expression in human forms of life and thought is entirely historical and therefore always moving with the stream of history. ... The dogmas of the Church are not immovable monuments erected on the shore of the ocean, but living currents and streams in the flux and reflux of its waters. 2 ?

According to Walgrave, the formal directive principle of culture is human freedom therefore, he diverges from Baur's concept of the Spirit as the directive force of culture. Man responds to God's self-revelation prior to theological reflection, "but in order to live by faith, the consciousness of divine revelation, or its living idea in man, has to become articulated so that men possess in a human way the glorious truth that divinely possesses them."28 Thus, for Walgrave, Church history is a fully historical matter which can be treated by modern historiographic methods. Still, the Church is more than just an historical expression. Its histarical expression is but the human response to abiding ideas for "self-conserving development is the only way in which ideas are able to keep themselves alive in the conditions of earthly existence."29

$$
\begin{aligned}
& 27 \mathrm{~J} \text {. Walgrave, Unfolding Revelation, pp. 14-15. } \\
& 28 \mathrm{~J} \text {. Walgrave, Unfolding Revelation, p. } 37 . \\
& 29 \mathrm{~J} \text {. Walgrave, Unfolding Revelation, p. } 16 .
\end{aligned}
$$


Ultimately, Walgrave finds the phrase "development of tradition" a more fitting description for what has been called "development of doctrine", or "development of dogma", and on this point he is close to Pelikan. Both theologians regard the doctrines and structures of the Church as man made institutions while, at the same time, both uphold an element of continuity within Christianity itself. On this point, they are in line with Baur's thinking. Their divergence from him comes over his assertion that the process of development itself, has meaning. Here, perhaps, Baur carried his idealism a little too far.

In conclusion to this study, it is important to reemphasize the great debt that the study of Church history and historical theology owes to F. C. Baur. Not only did he demonstrate the ultimate historicity of the Church and theology, but, through persistence and courage, he forced many theologians to face the problem of faith and history as their own. The fact that his historical works on the Church are still valued today, and, further, that a minor Baur renaissance is going on in theological circles today, is itself adequate testimony to his penetrating insight into the problems of Church history and historical theology. The problems which Baur wrestled with are still our own, and even though his solution may not suffice for our time, certainly his catagories and ideas provide a wealth of theological material out of which may come an answer for our own time. 


\section{A. BOOKS}

Allison, Henry E. Lessing and the Enlightenment. Ann Arbar, Mich: The University of Chicago Press, 1966.

Altholz, Josef I. The Churches in the Nineteenth Century. New York: The Bobbs-Merrill Company, Inc., 1967.

Artz, Frederick B. Reaction and Revolution. New York: Harper and Brothers Publishers, 1934.

Barth, Karl. Protestant Theology in the Nineteenth Century. Valley Forge: Judson Press, 1973.

Baur, Ferdinand Christian. Geschichte der Christlichen Kirche. zweite auflage, fünfter band, Leipzig: Fues's Verlag (R. Reisland), 1877.

- Ausgewählte Werke in Einzelausgaben. herausgegeben von Klaus Scholder, bande I, II. Stuttgart-Bad Cannstatt: Friedrich Frommann Verlag (Günther Holzboog), 1963.

- The Church History of the First Three Centuries. 2 vols., 3rd. ed., trans. Rev. Allen Nenzies. London: Willians and Norgate, 1878.

Biro, Sydney Seymour. The German Policy of Revolutionary France. vol. 1. Cambridge, Mass: Harvard University Press, 1957.

Bloesch, Donald. The Reform of the Church. Grand Rapids, Mich.: william B. Eerdmans Publishing Company, 1970.

Braaten, Carl E. History and Hermeneutics. vol. II of New Directions in Theology Today. Philadelphia: The Westiminster Press, 1974.

Brinton, Crane. A Decade of Revolution. New York: Harper and Brothers, Publishers, 1934 .

- The Shaping of Modern Thought. Englewood Cliffs, N.J.: Prentice Hall Inc., 1963.

Bultmann, Rudolph. Theology of the New Testament. vol. II, trans, by Kendrick Grobel. New York: Charles Scribner's Sons, 1955.

Dilthey, Wilhelm. Gesammelte Schriften. vol. IV. Stuttgart: B.G. Teubner Verlagsgesellschaft, 1959.

Dorner, J.A. History of Protestant Theology Particulary in Germany. vol. II, trans. George Robson and Sophia Taylor. New Yorks AMS Press, 1970.

Esposito, Joseph L. Schelling's Idealism and Philosophy of Nature. Lewisburg: Buckness University Press, 1977. 
Fraedrich, G. Ferdinand Christian Baur: der Begründer der Tüblnger Schule als Theologe, Schriftsteller und Charakter. Gotha:

Friedrich Andreas Perthes, 1909.

Geiger, Wolfgang. Spekulation und Kritik. Munchen: Chr. Kaiser Verlag, 1964.

Hayner, Paul Collins: Reason and Existence: Schell1ng's Ph1losophy of History. Ieiden, Netherlands: E.J. Brill, 1967.

Hegel, G.W.F. Lectures on the Philosophy of History. trans. J. Sibree. Lond on: George Bell and Sons, 1902.

- The Difference between Fichte's and Schelling's System of Philosophy. trans. H.S. Harris and Walter Cerf. Albany, N.Y.: State University of New York Press, 1977.

Hirsch, Emanuel. Geschichte der neuern evangelischen Theologie im Zusammenhang mit den allgemeinen Bewegungen des europaischen Denkens. vol. IV, 2nd. ed. Gutersloh: Verlagshaus Gerd Mohn, 1950; vol. V. Gutersloh: C. Bertelmanns Verlag, 1954.

Hodgson, Peter C. ed. and trans. Ferainand Christian Baur on the Writing of Church History. New York: Oxford University Fress, 1968.

- The Formation of Historical Theology. New York: Harper and Row, Publishers, 1966.

Hume, David. An Enquiry Concerning Human Understanding. Chicago: The Open Court Publishing Co., 1927.

Igger, George. The German Conception of History. Commecticut: Wesleyan University Press, 1968.

Janosi, Friedrich Engel. The Growth of German Historicism. series 62 of the John's Hopkins University Studies in Historical and Political Science. Baltimore: John's Hopkins University Press, 1944.

Kant, Immanuel. Religion Within the Limits of Reason Alone. trans. by Theodore Greene and Hoyt H. Hudson. New York: Harper and Row. Publishers, 1956.

Kaufmann, Walter. Hegel: A Reinterpretation. Garden City, New York: Doubleday and Company, Inc., 1966.

Lessing, Gotthold. On the Proof of the Spirit and of Power. trans. by Henry Chadwick. Stanford, Cal: Stanfard University Press, 1956.

Locke, John. An Essay Concerning Human Understanding. Great Books of the Western World, vol. 35. Chlcago: Encyclopedia Britannica, 1952. 
- The Reasonableness of Christianity. ed. by I.T. Ramsey. Stanford, Cal: Stanford University Press, 1958.

Pelikan, Jaroslav. Development of Christian Doctrine: Some Historical Prolegomena. New Haven, Conn.1 Yale University Press, 1969.

- Historical Theology. London: Hutchinson of London, 1971. - The Christian Tradition: A History of the Development of Doctrine. vol. I. Chicago: The University of Chicago Press, 1971 .

Pinson, Koppel S. Modern Germany: Its History and Civilization. 2nd. ed. New York: The Macmillan Company, 1966.

Redeker, Martin. Schleiermacher: Iife and Thought. trans. by John Wallhausser. Philadelphia: Fortress Press, 1973.

Schelling. F.W.J. System des transcendentalen Idealismus. Hamburg: Felix Meiner Verlag, 1962.

Schleiermacher, F. On Religion: Speeches to its Cultured Despisers. New York: Harper Torchbooks, 1958. $19 ; 3$.

The Christian Faith. 2 vols. New York: Harper Torchbooks,

Schweitzer, Albert. Paul and His Interpreters. London: Adam and Charles Black, 1912 .

- The Quest of the Historical Jesus. London: Adam and Charles BIack, 1910.

Seidel, George. Activity and Ground: Fichte, Schelling, and Hegel. New York: Georg Olms Verlag Hildesheim, 1976.

Senft, Christoph. Wahrhaftigkeit und Wahrheit: Die 'ineologie des 19. Jahrhunderts zwischen Orthodoxie und Aufklarung. Tübingen: J.C.B. Mohr, 1956 .

Snyder, Howard A. The Problem of Wineskins: Church Structure in a Technological Age. Downers Grove, IIl.: Inter Varsity Press, 1975.

Stern, Fritz. ed. The Varieties of History. New Yark: Vintage Books, 1973.

Sydenham, N.J. The French Revolution. New York: Capricorn Books, 1966.

Tillich, Paul. Perspectives on 19th and 20th Century Protestant Theology. ed., C. E. Braaten, New York: Harper and Row Publishers, 1967.

Walgrave, Jan. Unfolding Revelation. Philadelphia: 'The Westminster Press, 1972 . 
Welch, Claude. Protestant Thought in the Nineteenth Century. vol. I. New Haven, Conn.: Yale University Press, 1972.

Williams, Colin W. The Church. vol. IV of New Directions in Theology Today. Philadelphia: The Westminster Press, 1968.

\section{B. PERIODICAI LITURATURE}

Baver, Karl. "Ferdinand Christian Baur als Kirchenhistoriker," Blätter fïr Wurttemberg1sche Kirchengeschichte, Neue Folge, XXVI (1922), $1-60$.

- "Zur Jugendgeschichte von Ferdinand Christian Baur (18051807)," Theologische Studien und Kritiken, XCV: 3/4 (1923-1924), $303-313$.

Baur, August. "Ferdinand Christian Baur," Protestantische Kirchenzeitung für das evangelische Deutschland, XXXIX: 29, 30 (July 1892), 661-67: 691-99.

Hefner, Philip. "Baur versus Ritschl on Early Christianity," Church History, XXXI: 3 (September 1962), 259-78.

Hester, Carl. "Gedanken zu Ferdinand Christian Baurs Entwicklung als Historiker anhand zweier unbekannter Briefe," Zeitschrift für Kirchengeschichte, 84: 2-3 (1973), 249-26́9.

Hilgenfeld, Adolph. "Ferdinand Christian Baur nach seiner wissenschaftlichen Entwickelung und Bedeutung," Zeitschrift für wissenschaftliche 'theologie, XXXVI: I: 2 (1893), $222-44$.

Hodgson, Peter C. "The Rediscovery of Ferdinand Christian Baur: A Review of the First Two Volumes of His Augewählte Werke," Church History, XXXIII: 2 (June 1964), 206-214.

Liebing, Heinz. "Ferdinand Christian Baurs Kritik an Schleiermachers Glaubenslehre," Zeitschrift für Theologie und Kirche, LIV: 2 $(1957), 225-43$.

- "Historical-Critical Theology," trans. by P. Hodgson, Journal for Theology and the Church, 3 (1967), 55-69.

Pfleiderer, Otto. "Zu Ferdinand Christian Baur's Gedachtnis," Protestantische Kirchenzeitung für das evangelische Deutschland, XXXIX: 25 (June, 1862), 565-73.

Scholder, Klause. "Ferdinand Christian Baur als Historiker," E'vangelische Theologie, XXI: 10 (1961), 435-58.

Seyerlen, Rudolph. "Ferdinand Christian Baur als akademischer Lehrer und Mensch," Zeitschrift für wissenschaftliche Theologie, XXXVI: I: 2 (1893), 244-254. 
C. ENCYCLOPEDIA AND BIOGRAPHICAL AR'CICLES

Haussleiter, J. "Ferdinand Christian Baur," In The New Schaff-Herzog Religious Encyclopedia, vol. 2. New York: Funk and Wagnalls Company (1908), 7-11.

Mulert, Herman. "Ferdinand Christian Baur," In Neue Deutsche Biographie vol. I. Berlin: Duncker und Humblot (1953), 670-671.

Tetz, M. "F.C. Baur," in Die Religion in Geschichte und Gegenwart, 3rd. ed., vol. I. Tubingen: J.C.B. Mohr (1957), 935-938.

Zeller, Eduard. "Ferdinand Christian Baur," In Allgemeine Deutsche Blographie, vol. II. Leipzig: Duncker und Humblot (1875), 172179. 